\title{
Late Miocene chondrichthyans from Lago Bayano, Panama: Functional diversity, environment and biogeography
}

\author{
Victor J. Perez, ${ }^{1,2}$ Catalina Pimiento, ${ }^{3,4}$ Austin Hendy, ${ }^{4,5}$ Gerardo González-Barba, ${ }^{6}$ Gordon Hubbell, ${ }^{7}$ \\ and Bruce J. MacFadden ${ }^{1,2}$

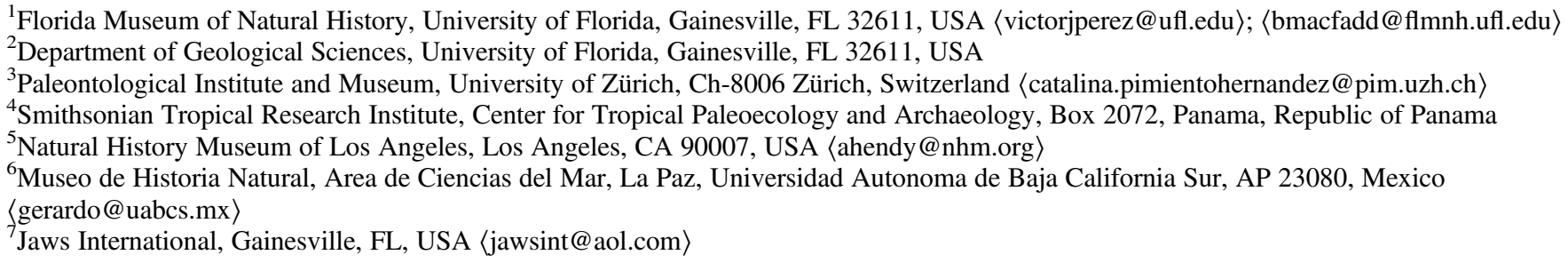

\begin{abstract}
This newly described chondrichthyan fauna from the late Miocene Chucunaque Formation of Lago Bayano reveals a prolific and highly diverse assemblage from Panama, and one of the richest shark faunas from the Neotropics. Strontium geochronology indicates an age of 10-9.5 Ma for the chonrichthyan-bearing strata. Field efforts resulted in 1429 identifiable specimens comprising at least 31 taxa, of which at least eight are new to the documented fossil record of Panama. With this information an analysis of functional diversity was conducted, indicating ecosystems dominated by generalist species feeding upon a wide range of organisms, from plankton to marine mammals. A probabilistic approach of paleobathymetric estimation suggests a neritic environment. Previous studies based on foraminifera have suggested that the Chucunaque Formation had a greater Pacific Ocean affinity, making this the first Miocene chondrichthyan fauna described from the Pacific shelf of Panama. However, our geographic comparisons show that this fauna has mixed Caribbean and Pacific biogeographic affinities, which likely supports the previously purported connection between chondrichthyan faunas during the late Miocene.
\end{abstract}

\section{Introduction}

Lago Bayano in Panama Province, Panama is an artificial lake that contains an extraordinarily rich assemblage of chondrichthyans. Hundreds of shark and ray teeth erode from host sediments and concentrate on the shorelines of emerged lake islands as a result of annual water-level fluctuations. Prior to the damming of the Rio Bayano drainage that created Lago Bayano, Stewart (1966) made a geological reconnaissance of this region and mapped what is now Lago Bayano as the Chucunaque Formation (Shelton, 1952). Chondrichthyan remains were noted to be common in the marine mudstones and sandstones of the deeply incised river valleys, although no collections were retained. More recently, Coates et al. (2004) mapped the Chucunaque Formation throughout the Darien Province of Panama. Even though marine vertebrates were not reported, this study confirmed a late Miocene age for the unit, and noted a foraminiferal assemblage indicating a Pacific Ocean affinity. In the present study, new biostratigraphic and $\mathrm{Sr}$-isotope analyses derived from marine invertebrate fauna yield ages of 10-9.5 Ma for chondrichthyan-bearing strata in Lago Bayano.

The closure of a Central American Seaway (CAS) and consequent formation of the Isthmus of Panama during the Neogene extremely affected tropical American (=Neotropical) marine communities and increased the biogeographic complexity of the region (e.g., Coates and Obando, 1996). Miocene chondrichthyan faunas are fundamental to understand these processes because they were: (1) abundant and widely distributed during this time, and (2) have been proven to be good paleobathymetry indicators of the deposits adjacent to the CAS (e.g., Pimiento et al., 2013a; Carillo-Briceño et al., 2015a). However, previous studies on Miocene chondrichthyans of Panama have been limited to Caribbean faunas (e.g., the Gatun Formation, Gillette, 1984; Pimiento et al., 2010; Pimiento et al., 2013a; the Culebra Formation, Pimiento et al., 2013b; and the Chagres Fromation, Carrillo-Briceño et al., 2015a). Hence, the chondrichthyan fauna of Lago Bayano is the first Miocene fauna from the Pacific shelf of Panama to be described. The only other chondrichthyan fauna described from the Pacific of Panama was the Eocene Tonosi Formation from the Azuero Peninsula (Vasquez and Pimiento, 2014). Other late Miocene shark assemblages from the region include Ecuador (Longbottom, 1979; Carrillo-Briceño et al., 2014), Venezuela (Sánchez-Villagra et al., 2000; Aguilera and Rodrigues de Aguilera, 2001; Carrillo-Briceño et al., 2015b), Jamaica (Donovan and Gunter, 2001), Costa Rica (Laurito and Valerio, 2008), and Grenada (Portell et al., 2008). All of these studies have provided a better understanding on the composition of marine communities during a time of rapid change. 
It has been argued that while most works on ancient chondrichthyan faunas provide valuable information about taxonomic diversity, they are somehow limited in their ecological interpretations because they ignore species functions in ecosystems (Moore, 2001; Hooper et al., 2002). To address this issue, functional diversity is often measured as a means to quantify the impact of species on ecosystems (Petchey and Gaston, 2006). The correlation that exists between tooth morphology and diet can be used to apply a functional diviersity approach to the study fossil chondrichthyan faunas (e.g., Bertolini, 1933; Moss, 1977; Cappetta, 1986, 1987, 2012; Frazzetta, 1988; Kent, 1994). Specifically, a classification scheme has been outlined by Kent (1994) in which chondrichthyan dentitions are subdivided into nine types: five homodont forms (cutting, grasping, clutching, crushing, and vestigial) and four heterodont forms (cutting-grasping, graspingcutting, grasping-crushing, and clutching-crushing). A more complex scheme was developed by Compagno (1990) that grouped sharks, rays, and chimaeroids into ecomorphotypes based on varying life histories, which incorporates the morphology, habitat, and behavior of each taxon. These ecomorphotypes have been utilized in numerous studies of extant sharks, especially those pertaining to conservation (Martin, 2005; Zhou and Griffiths, 2008; Lucifora et al., 2011; Grogan et al., 2012; Ritter, 2014), but have not been employed in many paleontological studies. Here, we integrate dentition types and ecomorphotypes as a measure of functional diversity. This approach provides novel information regarding the function of chondrichthyan species in the ecosystems adjacent to the CAS during the late Miocene.

This paper describes the taxonomy and systematics of the chondrichthyan fauna from Lago Bayano and interprets the diversity, paleoenvironment, and paleobiogeographic significance of this new and prolific marine vertebrate fauna. These interpretations will be based in functional diversity analyses and a unique approach toward analyzing paleobathymetry. We will show that this new discovery sheds a light on the dynamics of ancient marine faunas in the New World tropics during the late Miocene.

\section{Geologic setting}

The thick sequence of Cretaceous through Neogene sediments that occupy the central lowlands paralleling the San Blas and Darien highlands of Darien Province in eastern Panama forms the Bayano, Chucunaque-Tuira, and Atrato basins (Stewart, 1966; Duque-Caro, 1990; Coates et al., 2004). The Chucunaque-Tuira and Atrato basins were subject to a detailed review by Coates et al. (2004) who established the lithostratigraphy used herein, provided biostratigraphic and paleobathymetric context, and interpreted their geological history. The Bayano Basin was not investigated, however, and our present understanding of the geology is built around the geological reconnaissance of Stewart (1966), extrapolation of Coates et al. (2004), and more recent mapping as a part of a broader study into the tectonic history of the Panama Isthmus (Montes et al., 2012a, 2012b). Attempts to map this region, locate contacts, and measure stratal thickness have been challenged by lack of exposure, discontinuous outcrops (often submerged or forested), and obscure folding and faults. In a general sense, the succession in the Lago Bayano area consists of Cretaceous volcanic intrusives (Darien Formation), Oligoceneearly Miocene agglomerates (Porcona Formation), early-middle
Miocene limestone (Clarita Formation), turbiditic sandstone and claystone (Membrillo Formation), overlain by late Miocene fossiliferous and conglomeratic sandstone and siltstone (Chucunaque Formation) (Terry, 1956; Stewart, 1966; Coates et al., 2004). These units can be observed along the shoreline of southern Lago Bayano, Rio Maje, Rio Tigre, Carratera Panamericana, and minor roads (Fig. 1; Table 1).

Stewart's (1966) original description of the geology in this region was done prior to the damming of the Rio Bayano and the formation of the artificial lake that is now Lago Bayano. In this initial description he noted the presence of chondrichthyan remains in Miocene-aged sandstones of the Chucunaque Formation in the deeply incised Rio Bayano and its tributaries. Other marine fossils (e.g., molluscs and foraminifera) were recognized in other Miocene-aged units, but chondrichthyan remains were restricted to the sandstone facies of the Chucunaque Formation. The construction of the Bayano Dam in 1976 flooded $350 \mathrm{~km}^{2}$ of rainforest to form Lago Bayano, making it difficult to reconstruct original sediment composition and sedimentary structures of the Chucunaque Formation at many of the chondrichthyan-bearing localities. The chondrichthyan remains utilized in this study are left as a residue among reworked gravel, sand, and mud grains along island shorelines. In the southeastern-most portion of the lake, exposed uneroded blocks comprise strongly weathered and sparsely fossiliferous orange mudstone. The islands in the northern portion of southern Lago Bayano contain a more varied range of facies, including fossiliferous, gritty orange sandstone and a fine-grained tuffaceous white sandstone.

In much of the Darien Province, the Chucunaque Formation of Shelton (1952) is Messinian in age (7.1-5.6 Ma), although Coates et al. (2004) suggested that it could be older than 9.4 Ma in the western part of their study area on the basis of calcareous nannofossil biostratigraphy. This age is consistent with ${ }^{87} \mathrm{Sr} /{ }^{86} \mathrm{Sr}$ dates of 10-9.5 Ma derived from calcerous Lindapectin shells that were deposited in association with the chondrichthyan remains on the shoreline of STRI 290138 (N 9.1552, W 78.7824) and STRI 300032 (N 9.1411, W 78.7545; Tables 1, 2). In July 2015, a research group returned to Lago Bayano and observed unusually low lake levels, which resulted in some minor exposures of the in situ fossiliferous layer along STRI 290116 and STRI 300032. Calcareous microfossils picked from this in situ layer were dated using ${ }^{87} \mathrm{Sr} /{ }^{86} \mathrm{Sr}$ isotopic ratios from STRI 300032, and found to be consistent with the ages of the Lindapectin (personal communication, A. Waite, 2016). This fauna is therefore Tortonian in age and correlative with the other important chondrichthyan-bearing units in Central and South America, including the Gatun Formation and Alajuela Formation of central Panama (Gillette, 1984; Pimiento et al., 2013a; MacFadden et al., 2017), Angostura Formation of Ecuador (Carrillo-Briceño et al., 2014), and upper Urumacro Formation of Venezuela (Carrillo-Briceño et al., 2015b).

\section{Materials and methods}

In 2010 we began to collect fossils from Miocene sediments exposed along the islands of Lago Bayano (Fig. 1). The sharks and ray teeth are most easily collected when lake levels are low and fossiliferous sedimentary zones are exposed. 


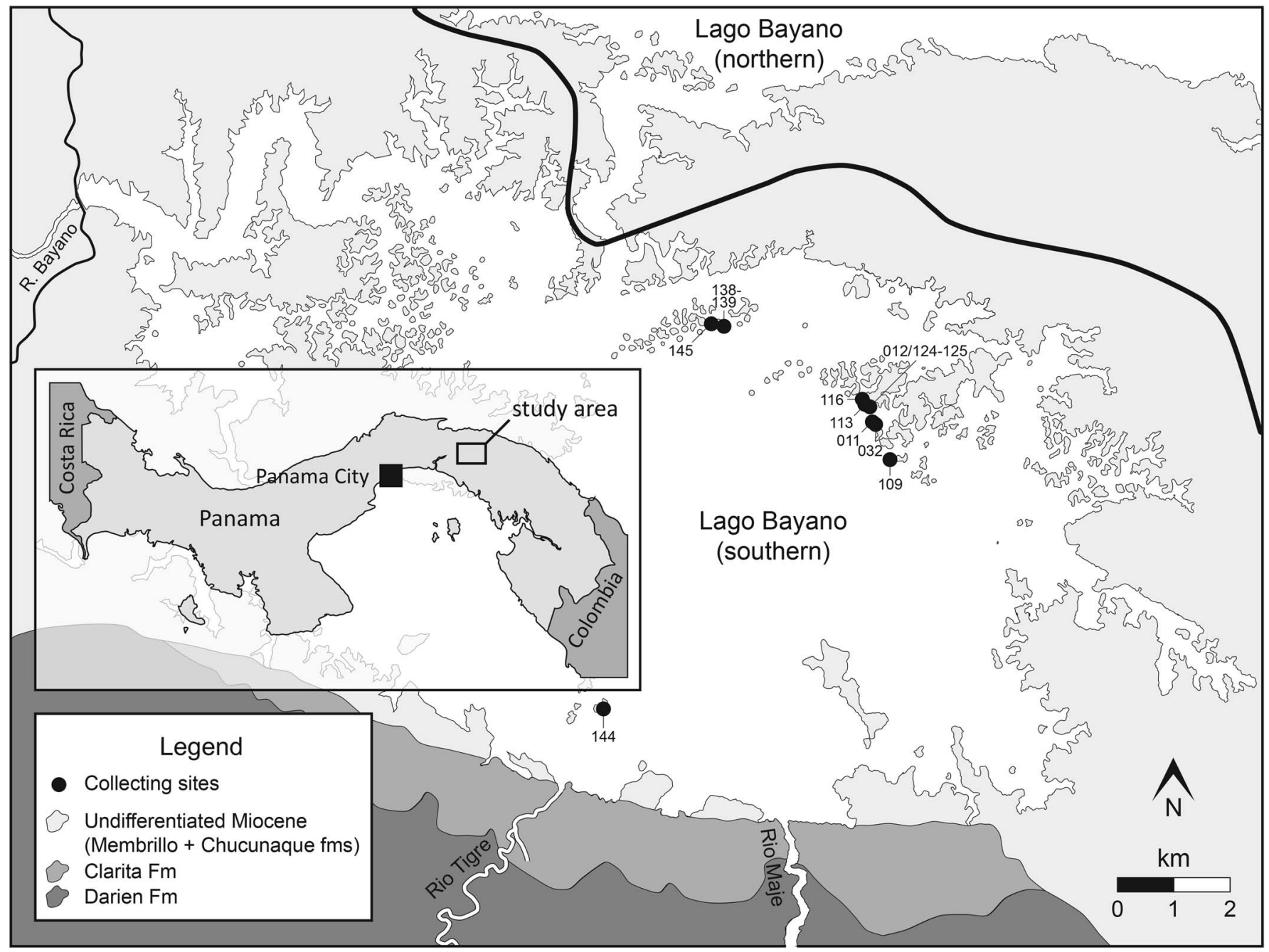

Figure 1. Map of Lago Bayano, Panama with collecting sites denoted by black circles. Numbers labelling each collecting site refer to the last three digits of the Smithsonian Tropical Research Institute (STRI) field number (Table 1).

Table 1. List of localities bearing chondrichthyan remains within Lago Bayano. GPS coordinates of STRI 300029 (Bayano 8) were improperly recorded and are not reported here; most likely this locality is within the cluster of islands that did bear chondrichthyan remains in southeastern Lago Bayano (Fig. 1). Specimens from Bayano 12 are all from a single locality, however sample labels and GPS coordinates were lost during transport and reported by FLMNH Site Key in the text. All GPS coordinates were taken using WGS84 datum. STRI locality (STRI Loc.) numbers can be searched in the STRI Geological Sample Database (http://biogeodb.stri. si.edu/jaramillo/fossildb). FLMNH $=$ Florida Museum of Natural History and STRI $=$ Smithsonian Tropical Research Institute.

\begin{tabular}{lllccc}
\hline STRI Loc. & FLMNH Site Name & FLMNH Site Key & Fig 1 ID & Latitude & Longitude \\
\hline 290109 & Bayano 1 & YPA066 & 109 & 9.1346 & -78.7509 \\
290113 & Bayano 2 & YPA095 & 113 & 9.1436 & -78.756 \\
290116 & Bayano 3 & YPA096 & 116 & 9.1454 & -78.7582 \\
290125 & Bayano 4 & YPA097 & $124-125$ & 9.1432 & -78.7549 \\
290139 & Bayano 5 & YPA098 & $138-139$ & 9.1545 & -78.7836 \\
290144 & Bayano 6 & YPA099 & 144 & 9.0942 & -78.7981 \\
290145 & Bayano 7 & YPA100 & 145 & 9.154 & -78.7853 \\
300029 & Bayano 8 & YPA101 & NA & - & - \\
300032 & Bayano 9 & YPA102 & 032 & 9.1411 & -78.7545 \\
430011 & Bayano 10 & YPA103 & 011 & 9.1413 & -78.7546 \\
430012 & Bayano 11 & YPA104 & 012 & 9.1432 & -78.7549 \\
unknown & Bayano 12 & YPA105 & NA & - & - \\
\hline
\end{tabular}

Chondrichthyan remains were collected from 12 localities within Lago Bayano, resulting in 1422 teeth and seven non-dental elements. Surface collecting was done at all 12 localities and produced 768 chondrichthyan teeth and two vertebral centra. Matrix was collected from five of the 12 localities and washed through a set of screens with $6,1.5,1.0$, and $0.5 \mathrm{~mm}$ mesh, which produced 654 chondrichthyan teeth, two vertebral centra, two stingray caudal spines, and one stingray dermal denticle. To illustrate that we have accurately sampled both surface and screenwashed material, randomized species accumulation curves were created 
Table 2. Strontium isotope data and age estimates from the Chucunaque Formation of Lago Bayano.

\begin{tabular}{lllllrc}
\hline Locality (STRI) & Height $(\mathrm{m})$ & Analytical sample & Taxon & ${ }^{87} \mathrm{Sr} /{ }^{86} \mathrm{Sr}$ & Age $(\mathrm{Ma})$ & Age range (Ma) \\
\hline 300032 & $\mathrm{n} / \mathrm{a}$ & LB-32A & Lindapecten $\mathrm{sp}$. & 0.708901 & 9.57 & $9.35-9.77$ \\
300032 & n/a & LB-32B & Lindapecten sp. & 0.70889 & 9.90 & $9.70-10.07$ \\
300032 & n/a & LB-32C & Lindapecten sp. & 0.7088864 & 10.00 & $9.82-10.20$ \\
290138 & n/a & LB-38A & Lindapecten sp. & 0.7089003 & 9.60 & $9.40-9.80$ \\
290138 & n/a & LB-38B & Lindapecten sp. & 0.7089039 & 9.50 & $9.25-9.67$ \\
290138 & n/a & LB-38C & Lindapecten sp. & 0.708899 & 9.65 & $9.42-9.82$ \\
\hline
\end{tabular}
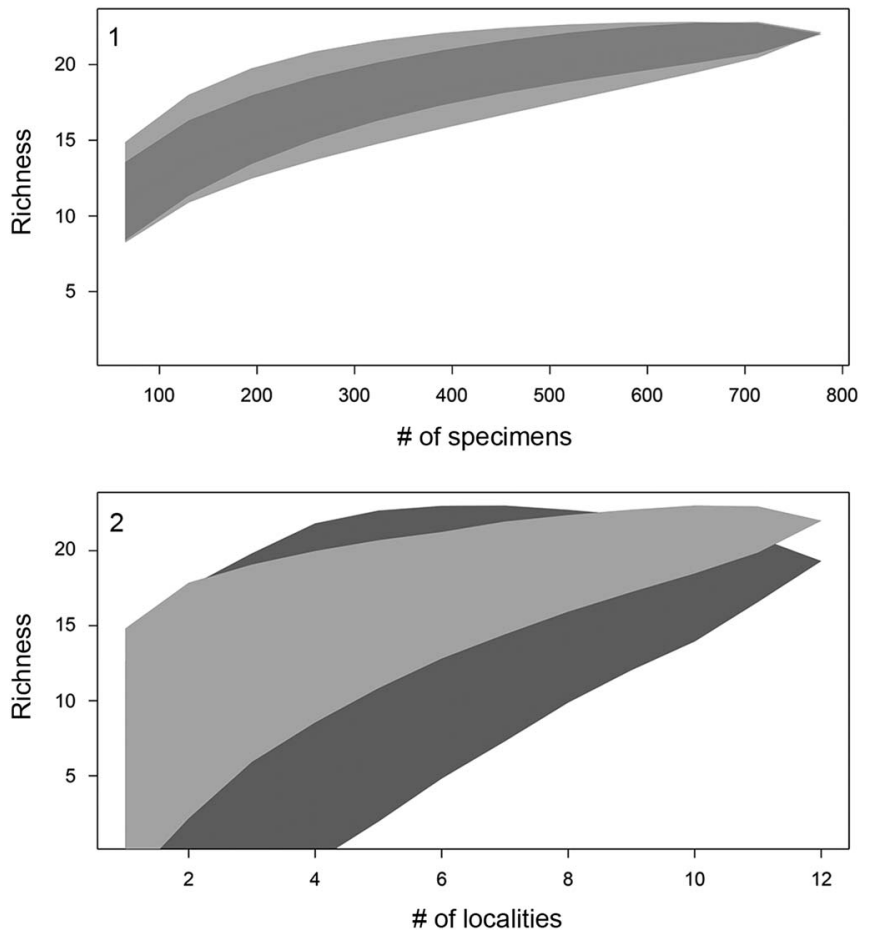

Figure 2. Sampling effort for surface-collected and screenwashed material via two randomized species accumulation curves. (1) Accumulation curves reported as number of specimens versus number of species (i.e., richness) for surfacecollected (light gray) and screenwashed material (dark gray), respectively; shaded polygons represent confidence intervals. (2) Accumulation curve reported as number of localities (i.e., collecting sites versus richness) for surface-collected (light gray) and screenwashed material (dark gray), respectively; shaded polygons indicates the confidence interval.

(Fig. 2) using the vegan package (Oksanen et al., 2010) in the program R (R Development Core Team, 2012).

Age estimates derived from ${ }^{87} \mathrm{Sr} /{ }^{86} \mathrm{Sr}$ isotopic ratios of marine calcareous shells and marine calcareous sediment may be compared to global ratios of ${ }^{87} \mathrm{Sr} /{ }^{86} \mathrm{Sr}$ through geologic time to estimate a geological age (Burke et al., 1982; Koepnik et al., 1985; Hodell and Woodruff, 1994; McArthur, 1994). Samples were obtained from the Lago Bayano assemblage itself, and from presumably coeval strata outcropping nearby (Table 2). Age estimates were determined using the Miocene and Pliocene portions of Look-Up Table Version 4:08/03 (Howarth and McArthur, 1997; McArthur et al., 2001) associated with the strontium isotopic age. Strontium isotope analyses of Lago Bayano samples used well-preserved calcitic shells and followed the sampling and analytical protocols of Kirby et al. (2007, 2008). These were performed on a Micromass Sector 54 Thermal Ionization Mass Spectrometer (TIMS) in the Department of Geological Sciences at UF. Strontium was loaded onto oxidized tungsten single filaments and run in triple collector dynamic mode. Data were acquired at a beam intensity of $\sim 1.5$ $\mathrm{V}$ for ${ }^{88} \mathrm{Sr}$, with corrections for instrumental discrimination made assuming ${ }^{86} \mathrm{Sr} /{ }^{88} \mathrm{Sr}$ ratio of 0.1194. Errors in measured ${ }^{87} \mathrm{Sr} /{ }^{86} \mathrm{Sr}$ are better than $\pm 0.00002(2 \sigma)$, based on long-term reproducibility of NBS $987\left({ }^{87} \mathrm{Sr} /{ }^{86} \mathrm{Sr}=0.71024\right)$. Due to the poor preservation of shell material in the Lago Bayano succession, ${ }^{87} \mathrm{Sr} /{ }^{86} \mathrm{Sr}$ isotope analyses were only conducted on samples from two localities (STRI 290138 and 300032) where calcitic shells of Lindapecten were present; at many localities even calcitic taxa are represented as external molds.

Information regarding biology, anatomy, distribution, habitat preferences, and feeding mechanisms were gathered from the literature cited below. Much of this information can be found in a coherent format in The IUCN Red list of Threatened Species (www.iucnredlist.org) or Fishbase (www.fishbase.org). Measurements of macro teeth were taken using calipers, whereas measurements of micro teeth were taken directly from SEM images. Crown height $(\mathrm{CH}=$ the distance between the crown tip and crown-root margin) and crown width $(\mathrm{CW}=$ maximum distance between the mesial and distal edge at the crown-root margin) were measured for labio-lingually flatten teeth (i.e., most taxa belonging to the subdivision Selachii). Crown length ( $\mathrm{CL}=$ tooth thickness, defined herein as the maximum distance between the labial and lingual edge in occlusal view) was additionally measured in teeth with a broad occlusal surface (i.e., those belonging to the superorder Batomorphii and the genus Mustelus). In order to measure $\mathrm{CH}$, a line was drawn from the crown apex perpendicular to the crown-root contact (e.g., Pimiento et al., 2010, fig. S2). It is important to note that many other authors will report the tooth height, which is generally a measurement of the entire tooth (crown and root) and is not directly comparable to the $\mathrm{CH}$ measurements reported herein.

Taxonomic composition is reported as a histogram depicting the relative abundance of chondrichthyan genera. Functional diversity is interpreted via two proxies (dentition types and ecomorphotypes). Dentition types, as defined by Kent (1994), were assigned to each taxon based on tooth morphology of fossil and modern representatives. For example, in the case of Carcharhinus plumbeus, fossil occurrences were limited to upper teeth that have a cutting-type morphology; however, based on the dentition of the living representatives, we can infer a cutting-grasping type dentition. Ecomorphotypes, as defined by Compagno (1990), were assigned to each taxon based on morphology, habitat, and behavior of modern analogs. Both proxies were then plotted as pie charts that illustrate the relative abundance of dentition types and ecomorphotypes, respectively. A weighted analysis of paleodepth frequency was performed using $\mathrm{R}$. This analysis incorporated the abundance (in the fossil assemblage) and depth preference (as reported in the literature) from taxa with modern analogs. Taxa that 
Table 3. Complete taxonomic list of the chondrichthyes of Lago Bayano, including a summary of all relevant data for the subsequent analyses. References for common depth ranges and biogeographic affinity (i.e., Atlantic vs. Pacific) can be found in the Systematic Paleontology section, ecomorphotypes are based on Compagno (1990), and descriptions of dentition types can be found in Kent (1994). * indicates a new taxon for the fossil record of Panama. $\dagger$ indicates an extinct species.

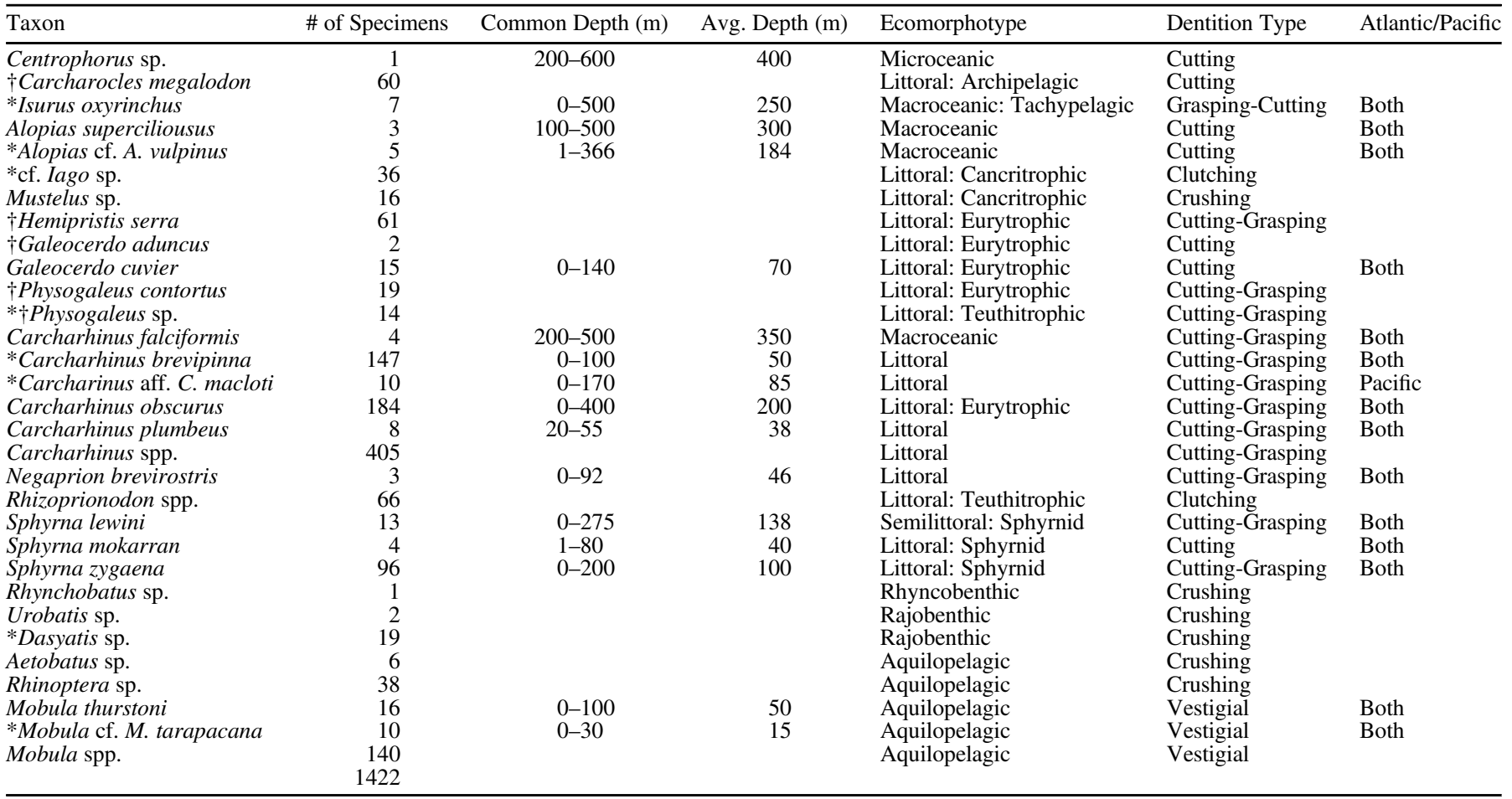

Table 4. Results of the weighted paleobathymetric analysis. Min and max values represent $95 \%$ confidence intervals. Previous estimates are based on Pimiento et al. (2013a) for the Gatun and Carrillo-Briceño et al. (2015a) for the Piña Sandstone facies of the Chagres Formation.

\begin{tabular}{|c|c|c|c|c|c|c|c|}
\hline \multirow[b]{2}{*}{ Formation } & \multicolumn{3}{|c|}{$\begin{array}{l}\text { Average depth } \\
\text { (m) }\end{array}$} & \multicolumn{3}{|c|}{$\underset{(\mathrm{m})}{\operatorname{Maximum}}$ depth } & \multirow{2}{*}{$\begin{array}{c}\text { Previous } \\
\text { Estimates (m) }\end{array}$} \\
\hline & Min & $\operatorname{Max}$ & Mean & Min & $\operatorname{Max}$ & Mean & \\
\hline $\begin{array}{l}\text { Chucunaque } \\
\text { Gatun }\end{array}$ & $\begin{array}{r}105 \\
50\end{array}$ & 119 & 112 & 208 & 236 & 222 & \\
\hline $\begin{array}{l}\text { Gatun } \\
\text { Chagres (Piña Sandstone) }\end{array}$ & $\begin{array}{r}50 \\
293\end{array}$ & $\begin{array}{r}61 \\
458\end{array}$ & $\begin{array}{r}53 \\
372\end{array}$ & $\begin{array}{r}98 \\
509\end{array}$ & $\begin{array}{l}118 \\
804\end{array}$ & $\begin{array}{l}108 \\
654\end{array}$ & $\begin{array}{c}<100 \\
200-300\end{array}$ \\
\hline
\end{tabular}

were unable to be assigned to the species level and those that are extinct were not included in this analysis in order to reduce potential bias. The data were then resampled 10,000 times and plotted as a histogram that provides a $95 \%$ confidence interval and a mean depth. This method was applied to the chondrichthyan fauna from the Chucunaque Formation, the Gatun Formation, and the Piña Sandstone facies of the Chagres Formation. The average and maximum depth estimates are reported in Figure 14 and Table 4. The average depth is the average of the usual depth range and the maximum depth is the upper limit of the usual depth range of each taxon. All data utilized for these analyses are available in Table 3 .

Institutional abbreviations and repositories.-The specimens described here are conserved in the Vertebrate Paleontology Collection of the Florida Museum of Natural History (FLMNH), University of Florida (UF). Specimen information can be found in the FLMNH Vertebrate Paleontology Database (http://www. flmnh.ufl.edu/vertpaleo-search/) or in the Smithsonian Tropical
Research Institute (STRI) Geological Sample Database (http:// biogeodb.stri.si.edu/jaramillo/fossildb).

\section{Systematic paleontology}

Class Chondrichthyes Huxley, 1880

Subclass Elasmobranchii Bonaparte, 1838

Order Squaliformes Goodrich, 1909

Family Centrophoridae Bleeker, 1859

Genus Centrophorus Müller and Henle, 1837

Type.-Centrophorus granulosus Müller and Henle, 1837 (Cappetta, 2012).

Centrophorus sp.

Figure 3.1, 3.2

Occurrence.-STRI 290109.

Description.-Small, asymmetric tooth with a broad crown and an apron indicative of the order Squaliformes. However, it is worth noting that the apron is not characteristic of all families within the order Squaliformes, as it is absent in the upper teeth of Dalatiidae, Oxynotidae, and Etmopteridae. The mesial edge is convex basally and straight apically, has coarse serrations near the base that become smaller apically and disappear prior to the apex; the distal edge is slightly convex with a complete cutting edge. There is a prominent notch on the distal edge; however, the distal heel is not entirely preserved. The labial face is 


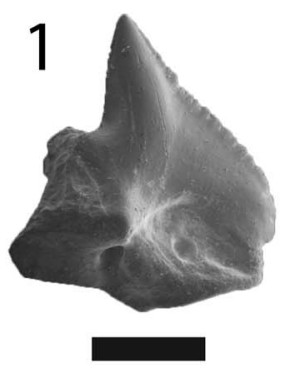

$1 \mathrm{~mm}$

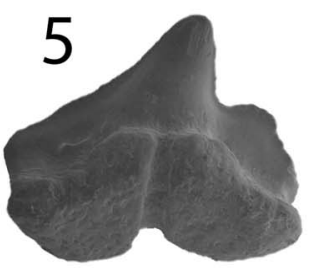

$0.5 \mathrm{~mm}$

9

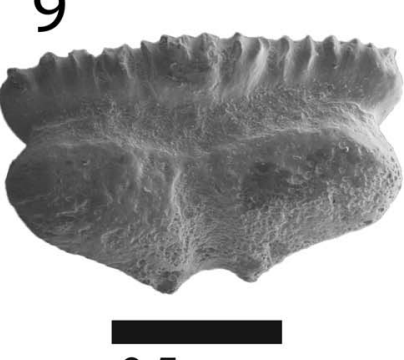

$0.5 \mathrm{~mm}$

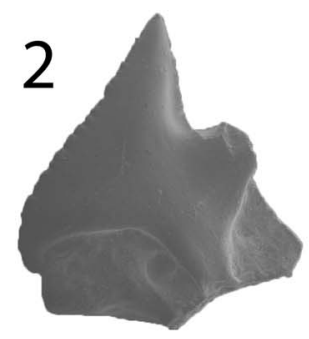

$1 \mathrm{~mm}$

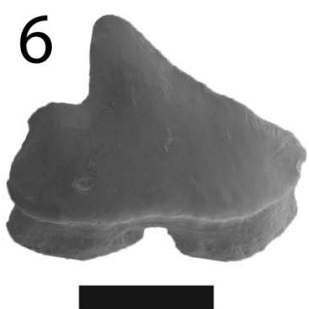

$0.5 \mathrm{~mm}$

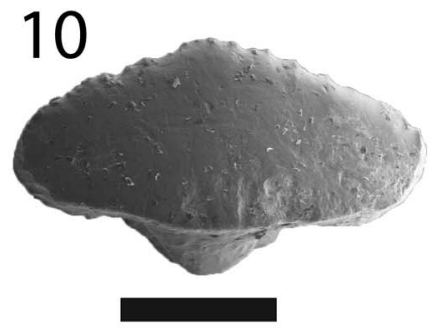

$0.5 \mathrm{~mm}$

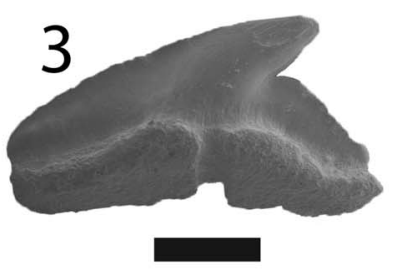

$0.5 \mathrm{~mm}$

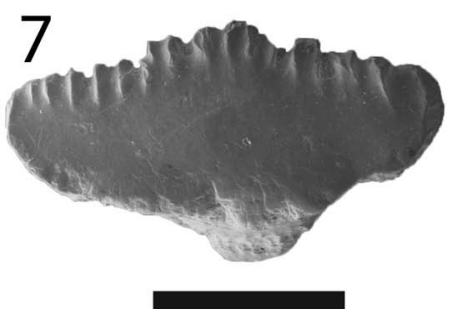

$0.5 \mathrm{~mm}$

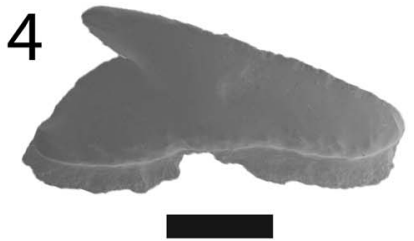

$0.5 \mathrm{~mm}$

8

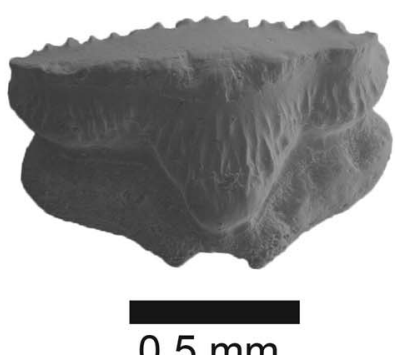

12

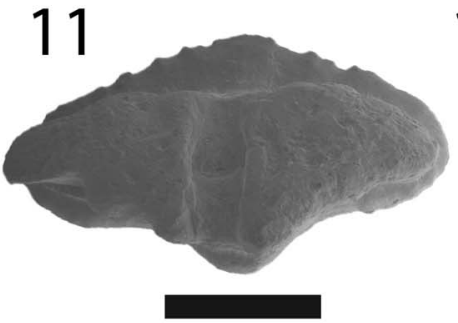

$0.5 \mathrm{~mm}$

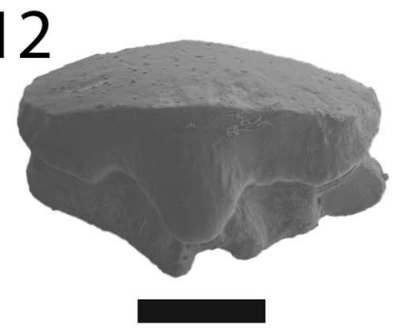

$0.5 \mathrm{~mm}$

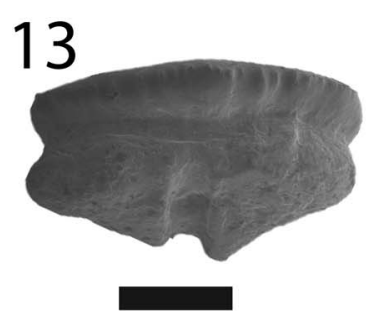

$1 \mathrm{~mm}$

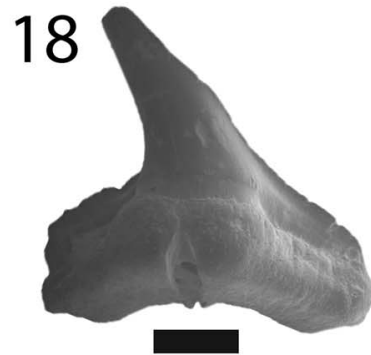

$1 \mathrm{~mm}$

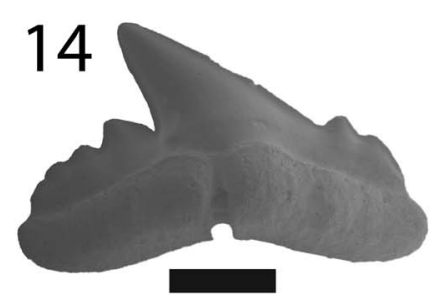

$1 \mathrm{~mm}$
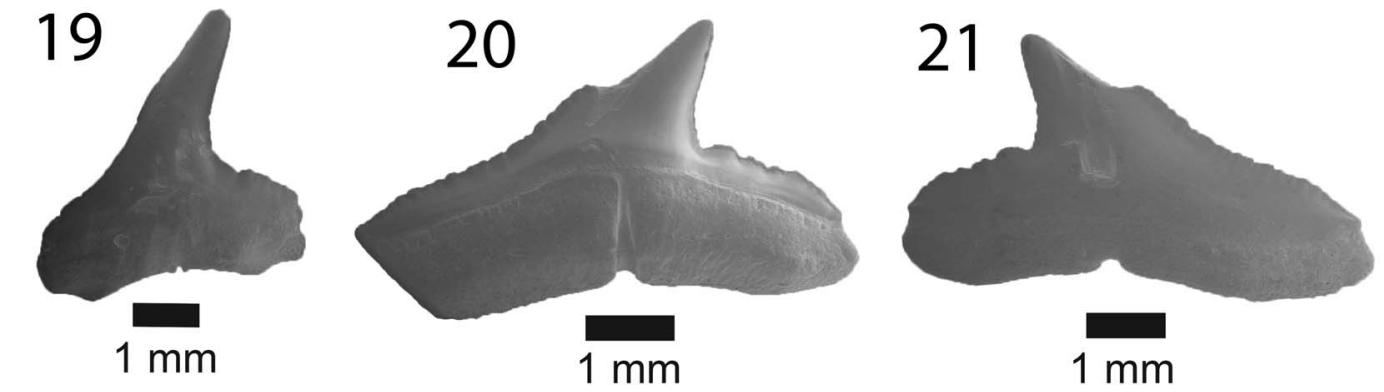

Figure 3. SEM images of specimens belonging to the subdivision Selachii. (1, 2) Centrophorus sp., UF 281349, lower anterolateral tooth in lingual and labial view, respectively; (3-6) cf. Iago sp.: $(\mathbf{3 , 4})$ UF 281382, lateral tooth in lingual and labial view, respectively; $(\mathbf{5 , 6})$ UF 281383, anterolateral tooth in lingual and labial view, respectively; (7-9) Mustelus sp., UF 281384, indeterminate position in occlusal, lingual, and baso-labial view, respectively; (10-13) Mustelus sp., UF 281386, indeterminate position in occlusal, basal, lingual, and labial view, respectively; (14-19) Physogaleus sp.: (14, 15) UF 281354, upper lateral tooth in lingual and labial view, respectively; (16, 17) UF 281353, anterior tooth in lingual and labial view, respectively; (18, 19) UF 281351, indeterminate position in lingual and labial view, respectively; (20, 21) Carcharhinus sp., UF 281338, pathologic upper tooth in lingual and labial view, respectively. 
flat with an elongate apron that extends well onto the root. The lingual face is convex with a short uvula that comes to a point. In labial view on the mesial side, the root is narrow, has a slightly concave basal margin, and a large foramen adjacent to the apron. On the distal side, the root is mostly broken off, but appears to have been larger than the mesial side. On the lingual face, there is a slight lingual bulge at the extremity of the uvula, a large infundibulum beneath the uvula, and a depression on the mesial side of the root. Centrophorus sp. from the Chucunaque Formation has a $\mathrm{CH}=2.06 \mathrm{~mm}$ and $\mathrm{CW}=2.28 \mathrm{~mm}$.

Material.—One isolated tooth; anterolateral: UF 281349.

Remarks.-No teeth from the order Squaliformes were identified from the Gatun Formation (Pimiento et al., 2013a); however, they dominate the Piña Sandstone facies of the Chagres Formation (Carrillo-Briceño et al., 2015a). In contrast, only a single tooth from the Chucunaque Formation was identified as belonging to this order. Cappetta $(1987,2012)$ mentioned that the apron does not extend past the root in Centrophorus; however, that character cannot be addressed with this specimen (Fig. 3.2). Cappetta (1987, p. 53) described Centrophorus as being "not rare in bathyal deposits" in the Miocene of France. Carrillo-Briceño et al. (2015a) identified 11 teeth as Centrophorus aff. C. granulosus. Extant Centrophorus granulosus are widespread with occurrences in the Eastern Atlantic, Western Central Atlantic, the Indian Ocean, and the Western Pacific (Compagno, 1984; Last and Stevens, 1994; and Compagno and Niem, 1998); however, it is not known from the Eastern Pacific (White et al., 2013). Extant representatives of the family Centrophoridae most commonly occur at depths of $1000-1500 \mathrm{~m}$, however they have been reported at depths as shallow as $50 \mathrm{~m}$ (Compagno et al., 2005).

Order Lamniformes Berg, 1958

Family Otodontidae Glikman, 1964

Genus Carcharocles Jordan and Hannibal, 1923

Type.-Carcharodon auriculates Blainville, 1818 (Cappetta, 2012).

\section{Carcharocles megalodon (Agassiz, 1835)}

Figure 4.1-4.5

Holotype.-An upper anterior tooth attributed to Carcharodon megalodon (TE-PLI 18) preserved in the Staatliches Museum für Naturkunde in Karlsruhe, Germany (Purdy et al., 2001). Originally described in Agassiz (1835, pl. 29, figs. 2, 3).

Occurrence.-STRI 290116, STRI 290125, STRI 290139, STRI 290144, STRI 290145, STRI 300029, STRI 300032, STRI 430011, and STRI 430012.

Description.-Large, triangular teeth; broad crown, uniform (or nearly uniform) serrations, convex lingual face with a distinct neck (i.e., bourlette), flat or convex labial face. Robust, thick, and U-shaped root with dispersed foramina; foramina tend to be concentrated at the crown-root contact on the labial face (Fig. 4.1, 4.2). Carcharocles megalodon exhibits monognathic and dignathic heterodonty. Upper teeth are broader, especially at the crown apex, with more convex cutting edges. Lower teeth are narrower with sigmoidal, straight, or concave cutting edges. There is an increasing asymmetry antero-laterally throughout the jaw. Posterior teeth are much smaller than anterior teeth with a more obtuse to nearly straight basal root margin. One specimen, UF 275108, has a reduced lateral cusplet (i.e., a vestigial cusplet; Fig. 4.3-4.5). Carcharocles megalodon from the Chucunaque Formation range from $\mathrm{CH}=24.6-88.2 \mathrm{~mm}$ and $\mathrm{CW}=28.6-88.0 \mathrm{~mm}$.

Materials. - Sixty isolated teeth; upper anterior: UF 275085, UF 275097, UF 275110, UF 275111, UF 275118, and UF 275132; lower anterior: UF 275129 and UF 275136; upper lateral: UF 275084, UF 275092, UF 275109, UF 275114, UF 275128, and UF 275139; lower lateral: UF 275086, UF 275131, and UF 275134; posterior: UF 275053; indeterminate position: UF 275051-52, UF 275096, UF 275098-99, UF 275107-08, UF 275112-13, UF 275117, UF 275126-27, UF 275130, UF 275133, UF 275135, UF 275137, UF 275138, UF 275148, UF 275151, and UF 275156.

Remarks.-The generic assignment of this species has been highly contested over the last century, with Carcharocles, Megaselachus, Carcharodon, Procarcharodon, and Otodus all being suggested as the most appropriate. A morphometrics study by Nyberg et al. (2006) determined that $C$. megalodon is not ancestral to Carcharodon carcharias, suggesting it belongs in a separate lineage with Otodus obliquus as the ancestor. Consequently, the oldest alternative generic assignment takes precedence, which is Carcharocles (Jordan and Hannibal, 1923). For a more detailed discussion on this topic see Pimiento et al. (2010). In the Chucunaque Formation, C. megalodon is intermediate in size between that of the Gatun Formation and the Yorktown Formation (Purdy et al., 2001; Pimiento et al., 2013a; Pimiento and Balk, 2015), but more closely aligns with the size range observed in the Gatun Formation, which has been proposed to be a paleonursery for $C$. megalodon (Pimiento et al., 2010). The lack of lateral cusplets and a broader crown are said to delineate $C$. megalodon from Carcharocles chubutensis, although neither of those characteristics is absolutely definitive (Kent, 1994). Lateral cusplets may still occur in juvenile individuals of C. megalodon (Pimiento et al., 2010), or as vestigial characters in adults (Fig. 4.3-4.5). Carcharocles megalodon had a cosmopolitan distribution, occurring in tropical to temperate coastal habitats (Gottfried et al., 1996; Purdy, 1996; Pimiento et al., 2016). Recent studies have calculated the most likely time of extinction of this species to be $2.6 \mathrm{Ma}$ (Pimiento and Clements, 2015). In the region, $C$. megalodon occurs in both the Caribbean and the Pacific (Longbottom, 1979; De Muizon and DeVries, 1985; Long, 1993; Iturralde-Vinent et al., 1996; Laurito, 1999; Aguilera and Rodrigues de Aguilera, 2001; Donovan and Gunter, 2001; Nieves-Rivera et al., 2003; Portell et al., 2008; Carrillo-Briceño et al., 2015a).

Family Lamnidae Müller and Henle, 1838 Genus Isurus Agassiz, 1843

Type.-Isurus oxyrinchus (Rafinesque, 1810) (Cappetta, 2012). Isurus oxyrinchus (Rafinesque, 1810)

Figure 4.6-4.16 

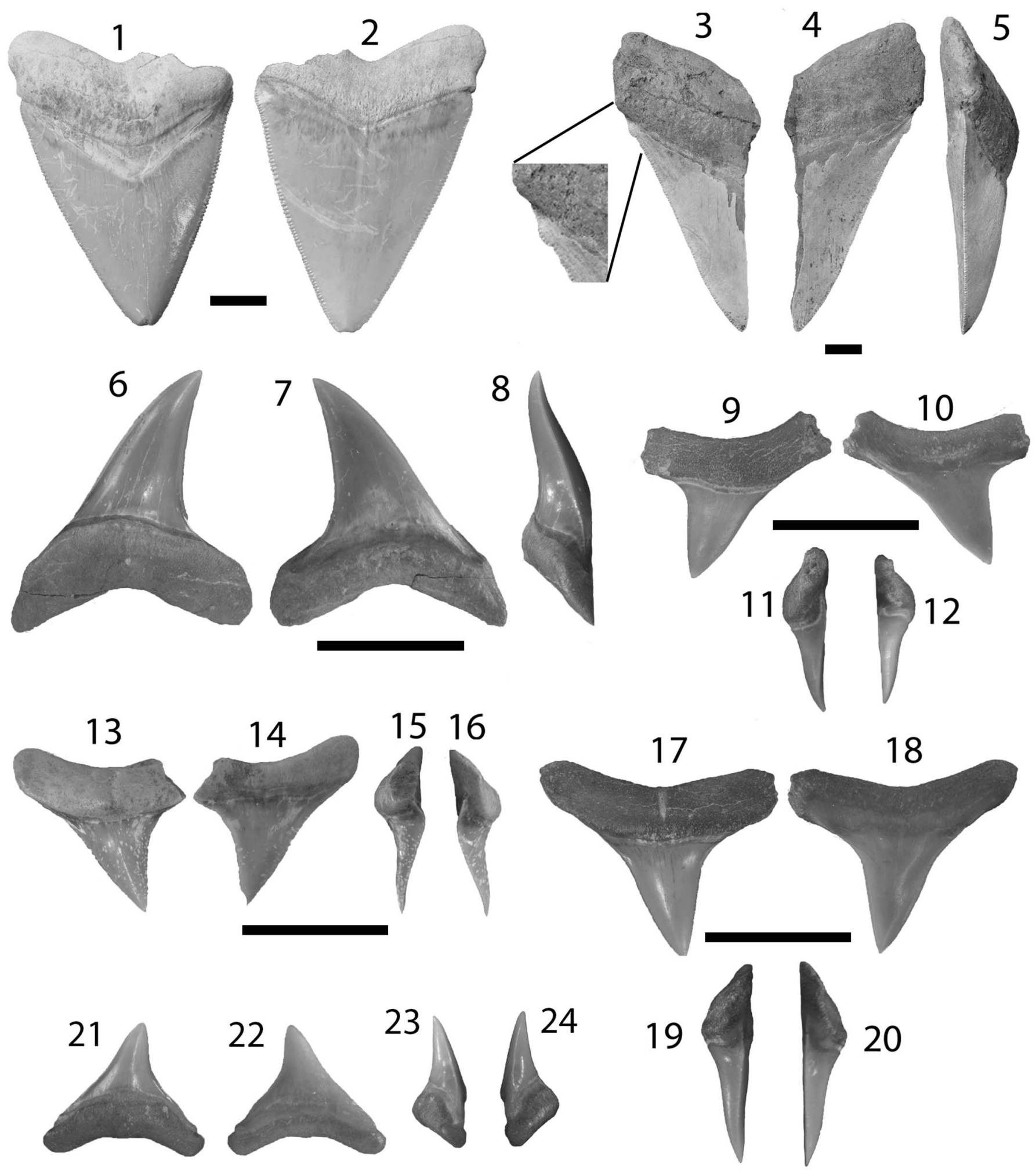

Figure 4. Lamniformes: Carcharocles, Isurus, and Alopias from the Chucunaque Formation. (1-5) Carcharocles megalodon (Agassiz, 1843): (1, 2) UF 275110, upper right anterior (most complete tooth) in lingual and labial view, respectively (scale bar $=5 \mathrm{~cm}$ ); (3-5) UF 275108, upper tooth bearing a vestigial lateral cusplet in lingual, labial, and lateral view, respectively (scale bar $=5 \mathrm{~cm}) ;(\mathbf{6}-\mathbf{1 6})$ Isurus oxyrinchus (Rafinesque, 1810): (6-8) UF 275124, lower right lateral in lingual, labial, and distal lateral view, respectively (scale bar $=1 \mathrm{~cm}$ ); (9-12) UF 281169, upper left lateral in lingual, labial, mesial lateral, and distal lateral view, respectively (scale bar $=1 \mathrm{~cm})$; (13-16) UF 281181, upper lateral tooth in lingual, labial, distal lateral, and mesial lateral view, respectively (scale bar $=1 \mathrm{~cm}$ ); (17-20) Alopias superciliosus (Lowe, 1840), UF 275057, lower position in lingual, labial, distal lateral view, and mesial lateral, respectively (scale bar = 1 cm); (21-24) Alopias cf. A. vulpinus (Bonnaterre, 1788), UF 281321, upper position in lingual, labial, mesial lateral, and distal lateral view, respectively $($ scale bar $=1 \mathrm{~cm})$. Photo credit: S. Moran and R. Leder. 
Holotype.-Originally described as Oxyrhina desori by Agassiz (1843, pl. 37, figs. 8-10) from the Miocene of Switzerland. Purdy et al. (2001) recognized one tooth among the syntypes (ETHGI P145) described by Agassiz (1843) as the second upper anterior of Isurus, and named it the lectotype of Isurus oxyrinchus.

Occurrence.-STRI 290145, STRI 300029, STRI 300032, and STRI 430011.

Description.-Moderately large, triangular teeth lacking serrations; with a convex lingual face and flattened labial face. The crown apex is reflexed toward the labial face, and has a sigmoidal or straight profile. The root is robust, lacks a nutrient groove, and has an angled or U-shaped basal margin with pointed or rounded root lobes. Anterolaterally, the crown becomes shorter, increasingly asymmetric, and less noticeably recurved labially; and the root lobes become shorter and more compressed (Kent, 1994; Purdy et al., 2001). Upper teeth differ from lower teeth in having a broader basal root angle and a much weaker sigmoidal profile (Kent, 1994). Isurus oxyrinchus from the Chucunaque Formation ranges from $\mathrm{CH}=8.6-15.0 \mathrm{~mm}$ and $\mathrm{CW}=13.3-14.1 \mathrm{~mm}$.

Materials.-Seven isolated teeth; upper laterals: UF 281169, UF 281173, and UF 281181; lower laterals: UF 275068, UF 275102, UF 275124, and UF 281172.

Remarks. - Labial recurvature of the apex is considered to be a diagnostic feature (Purdy et al., 2001; Reis, 2005); however, Purdy et al. (2001) noted that this feature is most apparent in upper anterior teeth and may not be present in lateral teeth. Portell et al. (2008) identified six I. oxyrinchus teeth from the Miocene of Carriacou, Grenada, with the largest tooth being a lateral tooth with $\mathrm{CH}=13.5 \mathrm{~mm}$ and $\mathrm{CW}=6.6 \mathrm{~mm}$. Teeth from the Chucunaque Formation are slightly larger than those from Carriacou. Anterior teeth from the Pungo River Formation range from $\mathrm{CH}=27.0-50.0 \mathrm{~mm}$ and $\mathrm{CW}=17.0-29.0 \mathrm{~mm}$, whereas anterior teeth from the Yorktown Formation range from $\mathrm{CH}=28.0-58.0 \mathrm{~mm}$ and $\mathrm{CW}=11.0-32.0 \mathrm{~mm}$ (Purdy et al., 2001). Measurements from Purdy et al. (2001) are not directly comparable to those in this study or that of Portell et al. (2008) because they were taken from anterior teeth. Even so, the teeth described by Purdy et al. (2001) represent much larger sharks that those observed in the Chucunaque Formation. Isurus oxyrinchus has also been observed from the Miocene of Brazil (Reis, 2005) and the Pliocene of Angola (Antunes, 1978). Isurus oxyrinchus is not recorded from the Gatun Formation of Panama (Pimiento et al., 2013a). Extant individuals are coastal and oceanic with a cosmopolitan distribution in temperate and tropical seas (Compagno et al., 2005), occurring most frequently from the Caribbean to Argentina (Compagno, 1984). Isurus oxyrinchus is predominantly epipelagic, but has been reported close inshore (Last and Stephens, 1994; Yamada et al., 1995; Mundy, 2005). Direct telemetry data in the North Pacific (Holts and Bedford, 1993), as well as temperature and occurrence data inferred from longline records in the Atlantic (Hoey, 1983), suggest that Isurus oxyrinchus has a preferred temperature range of $14-22^{\circ} \mathrm{C}$ (Heist et al., 1996). This temperature range corresponds with the common depth range of $100-150 \mathrm{~m}$ observed by Bianchi et al. (1999), however Compagno et al. (2005) reported a depth range of $0-500 \mathrm{~m}$.

$$
\begin{gathered}
\text { Family Alopiidae Bonaparte, } 1838 \\
\text { Genus Alopias Rafinesque, } 1810
\end{gathered}
$$

Type.-Alopias macrourus Rafinesque, 1810 (Cappetta, 2012).

$$
\text { Alopias superciliosus (Lowe, 1841) }
$$

Figure 4.17-4.20

Holotype.-Originally described as Alopecias superciliosus by Lowe (1841, p. 39) based on a single young specimen with no mention of its provenance. According to Eschmeyer (1998), the holotype is unknown; however, the type locality is Madeira, eastern Atlantic (Compagno, 2001, p. 83).

Occurrence.-STRI 300032 and STRI 430011.

Description.-Small to moderate-sized, triangular crown that is broad, erect, and lacks serrations. The mesial edge is straight to slightly convex, while the distal edge is straight to slightly concave. The lingual face is convex and the labial face is flat with enameloid extending well onto the root. Flattened root with rounded root lobes, distinct nutrient groove, and obtusely angled basal margin. The moderately broad crown and distally oriented asymmetry indicate a lateral position (Kent, 1994; Purdy et al., 2001). Alopias superciliosus from the Chucunaque Formation has a $\mathrm{CH}=4.2-10.3 \mathrm{~mm}$ and a $\mathrm{CW}=6.3-15.4 \mathrm{~mm}$.

Materials.-Three isolated teeth; lower lateral: UF 275057, UF 281318, and UF 281319.

Remarks.-Alopias differs from Isurus in having a shorter, broader crown with a concave basal root margin. Alopias superciliosus differs from Alopias cf. A. vulpinus in having a more slender crown, a distinct nutrient groove, and less robust root lobes (Kent, 1994). Alopias superciliosus is an uncommon species, with only three teeth identified from the Chucunaque Formation. Purdy et al. (2001) only described a single anterior tooth from the Pungo River Formation, and Kent (1994) stated that $A$. superciliosus is uncommonly found in the Calvert Formation of the Chesapeake Bay region. The anterior tooth of Alopias cf. A. superciliosus reported by Purdy et al. (2001) has a height of $13 \mathrm{~mm}$ and a width of $9 \mathrm{~mm}$. Extant individuals in the genus Alopias reach a maximum TL $=6 \mathrm{~m}$ (Springer and Gold, 1989), although half of the body length is represented by its elongated caudal fin (Kent, 1994). Alopias superciliosus has been reported from the lower Miocene of North Carolina (Case, 1980); the middle Miocene of Parma, Italy (CigalaFulgosi, 1983) and Lisbon, Portugal (Antunes, 1970); the late Miocene of Panama (Carrillo-Briceño et al., 2015a); and the Pliocene of Tuscany, Italy (Cigala-Fulgosi, 1988). The extant species has a circumglobal distribution in tropical and temperate seas; occurring in coastal waters over continental shelves, sometimes close inshore in shallow waters, and far from land in open ocean (Compagno, 1984). Alopias superciliosus is a highly migratory species found in oceanic, pelagic, and near 
bottom waters at depths of 0-730 $\mathrm{m}$ (McMillan et al., 2011), but most frequently occurs between 100 and $500 \mathrm{~m}$ (Compagno, 1984, 2001; Compagno et al., 2005; Mundy, 2005). Alopias superciliosus is more tolerant of cold water, as low as $6^{\circ} \mathrm{C}$, than most other sharks identified from Lago Bayano and has been observed occupying colder, deep water $\left(200-550 \mathrm{~m}\right.$ and $\left.6-11^{\circ} \mathrm{C}\right)$ during the day and shifting to warmer, mixed layers at night (50-130 $\mathrm{m}$ and $15-26^{\circ} \mathrm{C}$; Smith et al., 2008).

\section{Alopias cf. A. vulpinus (Bonnaterre, 1788)}

Figure 4.21-4.24

Holotype.-Originally described as Squalus vulpinus by Bonnaterre (1788, p. 9, pl. 85, fig. 349). According to Eschmeyer (1998), the holotype is unknown; however, the type locality is the Mediterranean Sea (Compagno, 2001, p. 86).

\section{Occurrence.-STRI 290109 and YPA105.}

Description.-Short, triangular teeth with a broad base and acutely pointed apex. The cutting edges are complete, but lack serrations. The mesial edge is straight and the distal edge is convex or vertical. The enameloid extends well onto the root on the labial face. Robust root usually lacking a nutrient groove, root lobes are rounded and elongate, basal margin is smoothly concave. Alopias cf. A. vulpinus from the Chucunaque Formation range from $\mathrm{CH}=1.2-7.1 \mathrm{~mm}$ and $\mathrm{CW}=4.5-8.3 \mathrm{~mm}$.

Materials.-Five isolated teeth; upper: UF 281321; indeterminate position: UF 275049 and UF 281320.

Remarks.—Kent (1994) identified two species of Alopias in the Chesapeake Bay region: Alopias superciliosus and Alopias latidens. However, Purdy et al. (2001) questioned the validity of Alopias latidens and, consequently, identified Alopias superciliosus and Alopias vulpinus as the only two thresher sharks that occur in the Lee Creek Mine. Descriptions of both A. latidens (Kent, 1994) and A. vulpinus (Purdy et al., 2001) align well with what is observed for Alopias cf. A. vulpinus from the Chucunaque Formation. Anterolateral teeth of A. vulpinus from the Pungo River Formation range from $\mathrm{CH}=8.0-15.0 \mathrm{~mm}$ and were estimated to have correlated to a $\mathrm{TL}=4.5-6 \mathrm{~m}$ (Purdy et al., 2001), which indicates that individuals from the Chucunaque Formation were smaller in size. Extant individuals of A. vulpinus have a cosmopolitan distribution in temperate and tropical seas, occurring in coastal and oceanic waters at depths from 0-550 m (Compagno, 1984; Cox and Francis, 1997); but most frequently are found near land at depths of 1-366 m (Compagno et al., 2005; Mundy, 2005). Young individuals are often found close inshore and in shallow bays (Compagno et al., 1989; Compagno et al., 2005). Alopias vulpinus is frequently encountered in temperate waters and more common in coastal environments than any of the other thresher sharks (Smith et al., 2008).

Order Carcharhiniformes Campagno, 1973 Family Triakidae Gray, 1851

Genus Iago Compagno and Springer, 1971
Type.—Eugaleus omanensis Norman, 1939 (Cappetta, 2012).

cf. Iago sp.

Figure 3.3-3.6

Occurrence.-STRI 290109 and YPA105.

Description.-Extremely small teeth with a short crown and root. The crown is distally arched with complete cutting edges. The mesial edge is slightly sigmoid, with a concave base and straight or concave apex; while the distal edge is convex or straight. There is a prominent rounded distal heel that forms a distinct notch. Lingual face is convex and the labial face is flat with weak folds at the crown base. The crown-root contact on the lingual face shows two distinct depressions on the mesial and distal edges where the crown thins out. On the labial face this contact is sharp, forming a distinct ridge. The root is high up on the lingual face with an observable lingual protuberance and distinct transverse furrow that penetrates the labial face. From the Chucunaque Formation cf. Iago sp. range from $\mathrm{CH}=0.61-0.86 \mathrm{~mm}$ and $\mathrm{CW}=1.01-1.67 \mathrm{~mm}$.

Materials.-Thirty-six isolated teeth; lateroposterior: UF 281374, UF 281376, UF 281379; indeterminate position: UF 281373; UF 281375, UF 281377, UF 281378, and UF 281380-83.

Remarks.-These are among the smallest shark teeth found in Lago Bayano and are only found through screenwashing efforts. Teeth of cf. Iago sp. are about half the size of those attributed to Physogaleus sp. There are distinct similarities to Iago oamanensis imaged in Herman et al. (1988), particularly the complete cutting edges with a rounded distal heel that forms an acute notch with the principle cusp. Lateral teeth of some species of Triakis, such as T. semifasciata and T. acutipinna, have a similar morphology (Herman et al., 1988); however, anterior teeth bear lateral cusplets that were not observed in any of the recovered specimens. Neither Iago nor Triakis have previously been reported from the fossil record of Panama. There are two extant species of Iago, I. garricki and I. omanensis, both of which have a bathydemersal habit. Iago garricki is a tropical species occurring in the Pacific Ocean on upper continental and insular slopes between 250 and $475 \mathrm{~m}$. Iago omanensis occurs in the Indian Ocean and prefers warm, poorly oxygenated water at depths of less than 110 to over $1000 \mathrm{~m}$ (Compagno et al., 2005).

\section{Genus Mustelus Linck, 1790}

Type.—Squalus mustelus Linnaeus, 1758 (Cappetta, 2012).

Mustelus sp.

Figure 3.7-3.13

Occurrence.-STRI 290109, STRI 290113, and YPA105.

Description.-The occlusal surface is smooth and has an elongate, roughly elliptical outline in apical view. The labial edge forms a prominent ridge at the crown-root margin and has a convex edge with folds that may be weak or strongly pronounced. The lingual face has a large central uvula with 
vertical, flexuous enameloid ripples and a somewhat sinuous outline. Root is thick with a medial groove that forms two short, asymmetric root lobes; there is a foramen nested within the medial groove that is oriented toward the labial side; the basal margin is flat, but slopes toward the labial face. The folds on the labial edge and the enameloid ripples on the lingual uvula are a diagnostic feature for the genus Mustelus (Herman, 1982; Cappetta, 1987; Leder, 2013). Two specimens of Mustelus sp. were imaged: UF 281384 in Figure 3.7-3.9 has a $\mathrm{CH}=0.23$ $\mathrm{mm}, \mathrm{CW}=1.17 \mathrm{~mm}$, and $\mathrm{CL}=0.64 \mathrm{~mm}$; and UF 281386 in Figure $3.10-3.13$ has a $\mathrm{CH}=0.27 \mathrm{~mm}, \mathrm{CW}=1.37 \mathrm{~mm}$, and a $\mathrm{CL}=0.64 \mathrm{~mm}$.

Materials.-Sixteen isolated teeth; indeterminate position: UF 281384-88.

Remarks.-Mustelus sp. from the Chucunaque Formation bears similarities to those described by Carrillo-Briceño et al. (2015a), with weak folding on the lingual uvula; however the images provided by Carrillo-Briceño et al. (2015a) do not show the labial face or the root. Mustelus sp. from the Pungo River Formation of the Lee Creek Mine have a CW $=1-1.3 \mathrm{~mm}$ and a CL roughly half the length of the CW (Purdy et al., 2001). Among the 28 extant species of Mustelus, all have a demersal habit, with most preferring subtropical to tropical conditions; however, Mustelus antarcticus, M. asterias, and M. mustelus prefer temperate waters (Compagno et al., 2005). Some species occur in up to $800 \mathrm{~m}$ depth (Kiraly et al., 2003), but most species generally occur at depths $<200 \mathrm{~m}$ (Compagno, 1984).

Family Hemigaleidae Campagno, 1984 Genus Hemipristis Agassiz, 1843

Type.-Hemipristis serra Agassiz, 1843 (Cappetta, 2012).

\section{Hemipristis serra Agassiz, 1843}

Figure 5.1-5.16

Holotype.-Originally described by Agassiz (1843, pl. 27, figs. 18-30) from the Miocene of southern Germany. Cappetta (2012, fig. 279G-I) illustrated two syntypes: an upper lateral, UM LEE 4, and a lower anterior, UM LEE 5.

Occurrence.-STRI 290109, STRI 290116, STRI 290125, STRI 290139, STRI 290145, STRI 300029, STRI 300032, and STRI 430011.

Description.-Upper teeth are broad and distally inclined with serrated cutting edges that terminate prior to the apex. The mesial edge is convex with relatively uniform, moderate-sized serrations. The distal edge is concave with serrations that increase in size apically. The root is compressed, bearing a strong lingual protuberence with a deep nutrient groove that forms a Z-shaped basal margin. There is obvious monognathic and dignathic heterodonty, with increasing asymmetry anterolaterally. Lower teeth are narrow, elongate, and unserrated with incomplete cutting edges and small lateral cusplets. The lingual face is convex, whereas the labial face is convex basally and flattens apically. The root is bilobate with a high lingual protuberance and deep nutrient groove. Hemipristis serra ranges from $\mathrm{CH}=10.4-32 \mathrm{~mm}$ and $\mathrm{CW}=4.4-32 \mathrm{~mm}$ in the Chucunaque Formation.

Materials.-Sixty-one isolated teeth; upper anterior: UF 281404; upper symphyseal: UF 281396; upper: UF 275032, UF 275047, UF 275054, UF 275065, UF 275078, UF 275093, UF 275115, UF 275122, UF 275144, UF 275152, UF 281174; lower: UF 275100, UF 281389-95, and UF 281405.

Remarks.- Hemipristis serra has a cutting-grasping type dentition (Kent, 1994) and the largest teeth among the carcharhiniform sharks from the Chucunaque Formation. Upper teeth of $H$. serra differ from the genus Carcharhinus in having a smooth apex and coarser serrations on the distal edge; lower teeth differ from the genus Carcharias in having incomplete cutting edges that only comprise roughly the upper third of the crown (Kent, 1994). Purdy et al. (2001) observed $H$. serra teeth from the lower Miocene Pungo River Formation and from the early Pliocene Yorktown Formation and postulated that $H$. serra increased in size throughout its evolutionary history. Teeth from the Chucunaque Formation are larger than that of the younger Pungo River Formation $(\mathrm{CH}=14.1-29.1 \mathrm{~mm}$ and $\mathrm{CW}=12.3-35.5 \mathrm{~mm})$ and smaller than the older Yorktown Formation $(\mathrm{CH}=16.4-41.0 \mathrm{~mm}$ and $\mathrm{CW}=14.0-43.5 \mathrm{~mm}$ ) and, as such, follow the trend proposed by Purdy et al. (2001). Pimiento et al. (2013a) observed size ranges of $\mathrm{CH}=5.4-21.6 \mathrm{~mm}$ and $\mathrm{CW}=5.2-29.0 \mathrm{~mm}$ from the Gatun Formation, which contradicts the trend observed by Purdy et al. (2001). However, the Gatun Formation was described as a shark paleonursery (Pimiento et al., 2010; Pimiento et al., 2013a), in which smaller teeth might be anticipated. Compagno (1988) noted an increase in distal serrations on upper lateral teeth of the extant Hemipristis elongatus during ontogeny; so observation of serration abundance on upper lateral teeth of $H$. serra from the Gatun Formation may be used to distinguish between juvenile and adult individuals. Hemipristis serra occurs in Atlantic and Pacific deposits from the middle Eocene to at least the Pleistocene; and was particularly abundant in neritic, warm-water environments during the Miocene and Pliocene (Cappetta, 1987). CarrilloBriceño et al. (2015a) observed $H$. serra in neritic Rio Indio facies and bathyal Piña Sandstone facies of the Chagres Formation. The much smaller, extant species, Hemipristis elongatus, is a coastal species that occurs inshore and offshore on continental and insular shelves, generally at depths of 1-132 m (Compagno, 1984; Last and Stephens, 1994; Compagno et al., 2005).

Family Carcharhinidae Jordan and Evermann, 1896 Genus Galeocerdo Müller and Henle, 1837

Type.—Squalus cuvier Peron and Lesueur, 1822 (Cappetta, 2012). Galeocerdo aduncus (Agassiz, 1835)

Figure 5.17-5.20

Holotype.-Originally described as Galeocerdo aduncus by Agassiz (1835, pl. 26, figs. 24-28) from the Schwabia region of southwestern Germany, according to Purdy et al. (2001). These specimens were deposited in Staatliches Museum für 

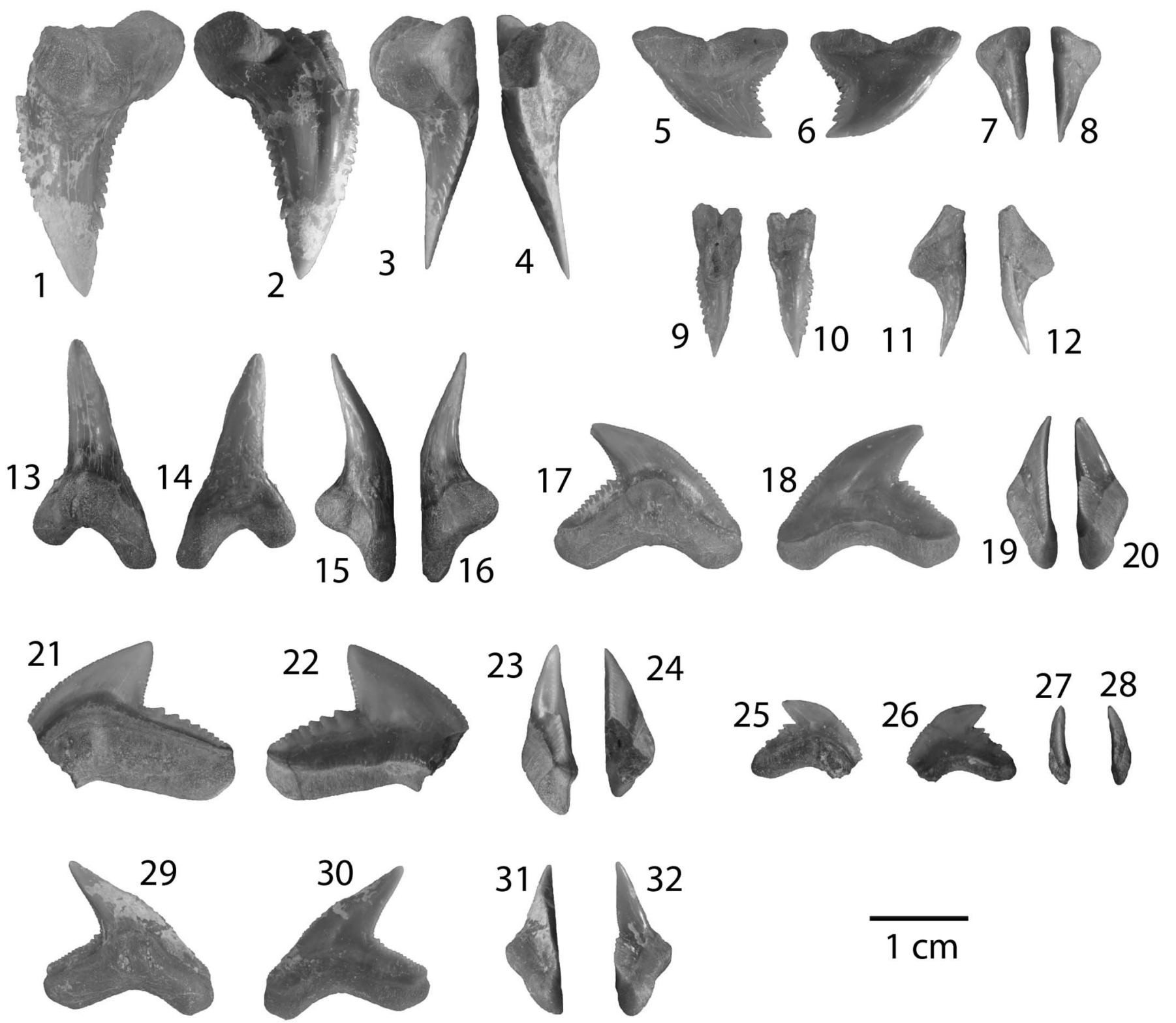

Figure 5. Carcharhiniformes I: Hemipristis, Galeocerdo, and Physogaleus from the Chucunaque Formation. (1-16) Hemipristis serra Agassiz, 1843: (1-4) UF 281404, upper anterior tooth in lingual, labial, distal lateral, and mesial lateral view, respectively; (5-8) UF 281174 , upper lateral tooth in lingual, labial, distal lateral, and mesial lateral view, respectively; (9-12) UF 281396, upper symphyseal tooth in lingual, labial, distal lateral, and mesial lateral view, respectively; (13-16) UF 281405, lower lateral tooth in lingual, labial, mesial lateral, and distal lateral view, respectively; (17-20) Galeocerdo aduncus (Agassiz, 1835), UF 275083, indeterminate position in lingual, labial, mesial lateral, and distal lateral view, respectively; (21-28) Galeocerdo cuvier (Peron and Lesueur, 1822): (21-24) UF 281397, indeterminate position in lingual, labial, distal lateral, and mesial lateral view, respectively; (25-28) UF 275145, indeterminate position in lingual, labial, distal lateral, and mesial lateral view, respectively; (29-32) Physogaleus contortus (Gibbes, 1849), UF 281170, indeterminate position in lingual, labial, mesial lateral, and distal lateral view, respectively. Photo credit: R. Leder.

Naturkunde, Karlsruhe, but have since been lost (Purdy et al., 2001).

\section{Occurrence.-STRI 290116 and STRI 430011.}

Description.-Moderately large teeth with a thick, distally arched crown; deeply notched on the distal edge. The mesial edge is convex with moderately sized serrations basally and fine serrations apically; the distal side has a coarsely serrated distal heel lacking secondary serrations and a concave cutting edge with fine serrations. The root is thick with a prominent lingual protuberance and concave basal margin; there are numerous nutrient pores and a transverse nutrient groove may be poorly developed (e.g., UF 275083) or distinct (e.g., UF 281398); the distal root lobes are lingually recurved at the extremities, indicating overlapping teeth within the dentition (Purdy et al., 2001). Galeocerdo aduncus from the Chucunaque Formation has a $\mathrm{CH}=10.2-11.7 \mathrm{~mm}$ and $\mathrm{CW}=18.7-18.9 \mathrm{~mm}$.

Materials.-Two isolated teeth; indeterminate position: UF 275083, UF 281398. 
Remarks.-There is much debate regarding the validity of Galeocerdo aduncus as a distinct species (Gottfried, 1993; Kent, 1994; Purdy et al., 2001; Ward and Bonavia, 2001). It has been suggested that $G$. aduncus and Physogaleus contortus represent teeth from a single species, with $G$. aduncus representing upper teeth and $P$. contortus representing lower teeth (Gottfried, 1993; Kent, 1994). However, the living tiger shark, Galeocerdo cuvier, lacks this marked dignathic heterodonty. Galeocerdo aduncus has a broader crown than Physogaleus contortus, but is narrower than Galeocerdo cuvier. Galeocerdo aduncus lacks the secondary serrations on the distal heel that are diagnostic of G. cuvier and the warped profile that is diagnostic of $P$. contortus. Galeocerdo aduncus was identified from the Gatun Formation by Gillette (1984), however the original specimens were missing and additional Galeocerdo specimens recovered by Pimiento et al. (2013a) were assigned to Galeocerdo cuvier. Our presumption would be that under greater scrutiny, with a particular focus on the distal cutting edge and the serrations on the distal heel, both $G$. aduncus and G. cuvier would be present in the Gatun Formation. Because the original holotype of $G$. aduncus described by Agassiz has since been lost, Purdy et al. (2001) referred to G. aduncus as a nomen dubium and, subsequently, classified the equivalent morphospecies as Galeocerdo sp. Herein, G. aduncus is recognized as a distinct species given the few unique characters discussed above, however, the tooth form of G. aduncus is quite similar to G. cuvier, implying a similar ecological niche. The teeth of G. cuvier are more robust and have a more advanced adaptation toward cutting, which may have given G. cuvier an advantage over G. aduncus.

\section{Galeocerdo cuvier (Peron and Lesueur, 1822)} Figure 5.21-5.28

Holotype.-Originally described as Squalus cuvier from the northwest coast of New Holland by Peron and Lesueur (1822).

Occurrence.-STRI 290109, STRI 290116, STRI 290145, STRI 300029, STRI 300032, and STRI 430011.

Description.-Moderately large, robust teeth with a distally angled crown. Weakly convex distal edge with coarse serrations on the heel that are secondarily serrated and fine serrations apical of a deep distal notch; strongly convex mesial edge with serrations that decrease in size around the same height as the distal notch. Root has a concave basal margin, central foramen absent or weakly present. Galeocerdo cuvier from the Chucunaque Formation has a $\mathrm{CH}=3.5-14.8 \mathrm{~mm}$ and $\mathrm{CW}=10.4$ $25.1 \mathrm{~mm}$.

Materials.-Fifteen isolated teeth; indeterminate position: UF 275045, UF 275060, UF 275062, UF 275082, UF 275095, UF 275105, UF 275120, UF 275145, and UF 281397.

Remarks.-Galeocerdo cuvier differs from Galeocerdo aduncus and Physogaleus contortus in having a broader crown with a more convex mesial edge and a convex distal edge. In profile view, the mesial edge of Galeocerdo cuvier is straight to nearly straight, whereas $P$. contortus appears to have a twist in the crown near the apex giving it a weakly sigmoidal appearance (Kent, 1994). Galeocerdo cuvier is an aggressive shark equipped with a cutting-type dentition bearing robust teeth adapted for both slicing and ripping (Frazzetta, 1988), which explains its wide variety of prey options (Kent, 1994). Teeth from the Gatun Formation, $\mathrm{CH}=7.4-17.8 \mathrm{~mm}$ and $\mathrm{CW}=$ 14.4-24.5 mm (Pimiento et al., 2013a), and from the Yorktown Formation, $\mathrm{CH}=13.5-29.1 \mathrm{~mm}$ and $\mathrm{CW}=24.4-33.0 \mathrm{~mm}$ (Purdy et al., 2001), are larger than those found in the Chucunaque Formation. According to Kent (1994), extant G. cuvier reach lengths up to $7.4 \mathrm{~m}$, but fossil evidence suggests that earlier individuals were likely less than half this length. Galeocerdo cuvier is a highly migratory species with circumglobal distribution in tropical and temperate seas occurring in: Western Atlantic: Massachusetts, USA to Uruguay, including the Gulf of Mexico and the Caribbean; Eastern Atlantic: Iceland to Angola; Indo-Pacific: Red Sea and East Africa to Hawaii and Tahiti, north to southern Japan, south to New Zealand; and Eastern Pacific: southern California, USA to Peru (Garcia, 1994). It has been recognized in a wide variety of habitats, but occurs most frequently at depths less than $140 \mathrm{~m}$ (Compagno, 1984, 1988; Smith, 1997; Compagno et al., 2005).

\section{Genus Physogaleus Cappetta, 1980}

Type.-Trigonodus secundus Winkler, 1876 (Cappetta, 2012).

$$
\text { Physogaleus contortus (Gibbes, 1849) }
$$

Figure 5.29-5.32

Holotype.-Originally described as Galeocerdo contortus from the Eocene of South Carolina and the Miocene of Virginia by Gibbes (1849, pl. 25, figs. 71-74).

Occurrence.-STRI 290109, STRI 290116, STRI 290145, STRI 300029, STRI 300032, and STRI 430011.

Description.-Moderately large teeth with a slender, distally angled crown. The mesial edge is finely serrated with a warped profile, while the distal edge is notched with fine serrations on the heel and even finer serrations apical of the notch. The root is robust with a U-shaped basal margin and a large lingual protuberance bearing a nutrient groove. Physogaleus contortus from the Chucunaque Formation range from $\mathrm{CH}=6.1-14.9 \mathrm{~mm}$ and $\mathrm{CW}=9.2-17.1 \mathrm{~mm}$.

Materials.-Eighteen isolated teeth; indeterminate position: UF 275037, UF 275059, UF 275064, UF 275069, UF 275125, UF 275146, UF 281170, and UF 281171.

Remarks.-Distinguishing features between Physogaleus and Galeocerdo are mentioned above, however it is worthwhile to also mention that Physogaleus has finer serrations on the distal heel with a less drastic distal notch and a more pronounced lingual protuberance on the root. The distribution of Physogaleus contortus is difficult to surmise given the confusion that exists regarding its distinction from the genus Galeocerdo (Cappetta, 1980, 1987, 2012; Gillette, 1984; Kent, 1994; Purdy et al., 2001; Ward and Bonavia, 2001) and recent re-assignment to the genus 
Physodon (Leder, 2013). Springer (1964) stated that the type specimen of Physodon muelleri described by Müller and Henle (1841) actually belonged to a male Scoliodon laticaudus, and chose to synonymize the two genera (Cappetta, 1987, 2012). Leder (2013) described Physodon (= Physogaleus) contortus from the Eocene of Crimea; in which he noted similarities with both Galeocerdo and Physogaleus, but overall determined it was unique and, consequently, chose to resurrect the genus Physodon described by Müller and Henle (1841). Cappetta (1980, 1987, 2012) described $P$. contortus as being a characteristic component of the Miocene deposits of the Gulf Atlantic Coastal Plain that does not occur in Europe; however, Purdy et al. (2001) recognized misidentifications by Storm (1894), Leriche (1927), and Caretto (1972) that actually represent $P$. contortus from Europe. Physogaleus contortus from the Gatun Formation range from $\mathrm{CH}=$ 10.0-11.1 and CW $=12-15.5 \mathrm{~mm}$ (Pimiento et al., 2013a) and from the Pungo River Formation range from $\mathrm{CH}=12.0$ $19.4 \mathrm{~mm}$ and $\mathrm{CW}=12.0-19.5 \mathrm{~mm}$ (Purdy et al., 2001). Purdy et al. (2001) noted that $P$. contortus is twice as common as Galeocerdo in the Lee Creek Mine, whereas only two specimens of $P$. contortus were identified from the Gatun Formation (Pimiento et al., 2013a). In the Chucunaque Formation, P. contortus $(\mathrm{N}=19)$ and Galeocerdo $(\mathrm{N}=17)$ have nearly the same abundance. The slender, more delicate crown of $P$. contortus indicates a greater reliance on grasping than cutting during feeding, suggesting a different ecological niche than that of Galeocerdo.

Physogaleus sp.

Figure 3.14-3.19

Occurrence.-STRI 290109 and YPA105.

Description.-Small teeth, with a triangular shape and a distally arched, labio-lingually compressed crown. The mesial edge is convex or straight; the distal edge is slightly concave to nearly straight. There is a strong distal notch with well-defined lateral cusplets on the distal heel; the mesial heel may or may not bear lateral cusplets. Anterior teeth are more erect and symmetrical than lateral teeth; anterior teeth have a $\mathrm{CH}: \mathrm{CW}$ ratio close to $1: 1$, whereas lateral teeth have a $\mathrm{CH}: \mathrm{CW}$ ratio closer to $1: 2$. Leder (2013) reported similar height:width ratios for Physogaleus tertius teeth of 1:1 to 5:6 for anteriors and 1:2 for the posterolateral positions. The root has a lingual bulge with nutrient pores at the crown-root margin and a prominent axial nutrient groove that penetrates the labial face; the labial face is narrow with a smooth, nearly horizontal crown-root margin. Physogaleus sp. from the Chucunaque Formation has a range of $\mathrm{CH}=1.61$ $3.21 \mathrm{~mm}$ and $\mathrm{CW}=1.81-3.83 \mathrm{~mm}$.

Materials.-Fifteen isolated teeth; anterior: UF 281353; upper: UF 281354, UF 281357; lower anterior: UF 281351, UF 281359; indeterminate position: UF 281352, UF 281356, UF 281358, and UF 281360.

Remarks.-Interpretation of Physogaleus and related genera, such as Galeorhinus and Physodon, among others, is highly debated. Cappetta $(1987,2012)$ suggested that fossils identified as Galeorhinus and Physodon may be male and female teeth belonging to the extinct genus Physogaleus. The genus Physogaleus has not yet been reported from Panama, with the exception of Physogaleus contortus, which has since been reassigned to the genus Physodon based on the work of Leder (2013). Galeorhinus cf. G. galeus identified from the Chagres Formation (Carrillo-Briceño et al., 2015a) shares many similarities with Physogaleus sp. reported herein; however, they are distinct. Galeorhinus often has a concave mesial apex and convex distal edge, lacks lateral cusplets on the mesial edge, and has robust serrations on the distal heel that rise high up the crown. These teeth are also similar to cf. Iago sp., but differ, especially, in terms of size and the presence of lateral cusplets. Physogaleus sp. is about twice the size of cf. Iago sp. and has well-defined lateral cusplets, although the presence of cusplets may vary depending on the position within the jaw. Physogaleus has been reported from the Eocene of Morocco, West Africa, Egypt, Belgium, Crimea, and Georgia, United States; the Oligocene of Belgium, France, and Hungary; and the Miocene of France (Cappetta, 1987; Leder, 2013).

\section{Genus Carcharhinus Blainville, 1816}

Type.-Carcharias melanopterus Quoy and Gaimard, 1824 (Cappetta, 2012)

Carcharhinus falciformis (Bibron, 1841 in Müller and Henle, 1839-1841)

Figure 6.1-6.4

Holotype.-Originally described as Carcharias (Prionodon) falciformis by Bibron (1841 in Müller and Henle, 1839-1841, p. 47). The holotype, MNHN 1134, a $528 \mathrm{~mm}$ female fetus from Cuba, resides in the Museum National d'Histoire Naturelle, Paris, France (Garrick et al., 1964; Compagno, 1984).

\section{Occurrence.-STRI 290109 and STRI 300032.}

Description.-Small, triangular teeth; relatively narrow crown, straight mesial edge, concave or angular distal edge, notch on mesial and distal edges marks a transition from coarser basal serrations to finer apical serrations. Thin root with a nutrient groove and a flat or obtusely concave basal margin. Features distinguishing $C$. falciformis from other Carcharhinus species are its small size, narrow crown with a notch on both cutting edges, and a relatively flat basal root margin. Carcharhinus falciformis from the Chucunaque Formation range from $\mathrm{CH}=$ $5.5-6.1 \mathrm{~mm}$ and $\mathrm{CW}=6.5-11.7 \mathrm{~mm}$.

Materials.-Four isolated teeth; upper lateral: UF 281160, UF 281161, and UF 281162.

Remarks.-Carcharhinus falciformis is a solitary species (Claro, 1994) and yet, is commonly caught by fisheries (Bonfil et al., 2009). However, this species has a relatively sparse fossil record; Pimiento et al. (2013a) reported three isolated upper teeth from the Gatun Formation and Purdy et al. (2001) referred to five teeth in the USNM collection from the Pungo River Formation. Pimiento et al. (2013a) recorded a range from $\mathrm{CH}=5.1-7.2 \mathrm{~mm}$ and $\mathrm{CW}=4.9-6.4 \mathrm{~mm}$; whereas Purdy 

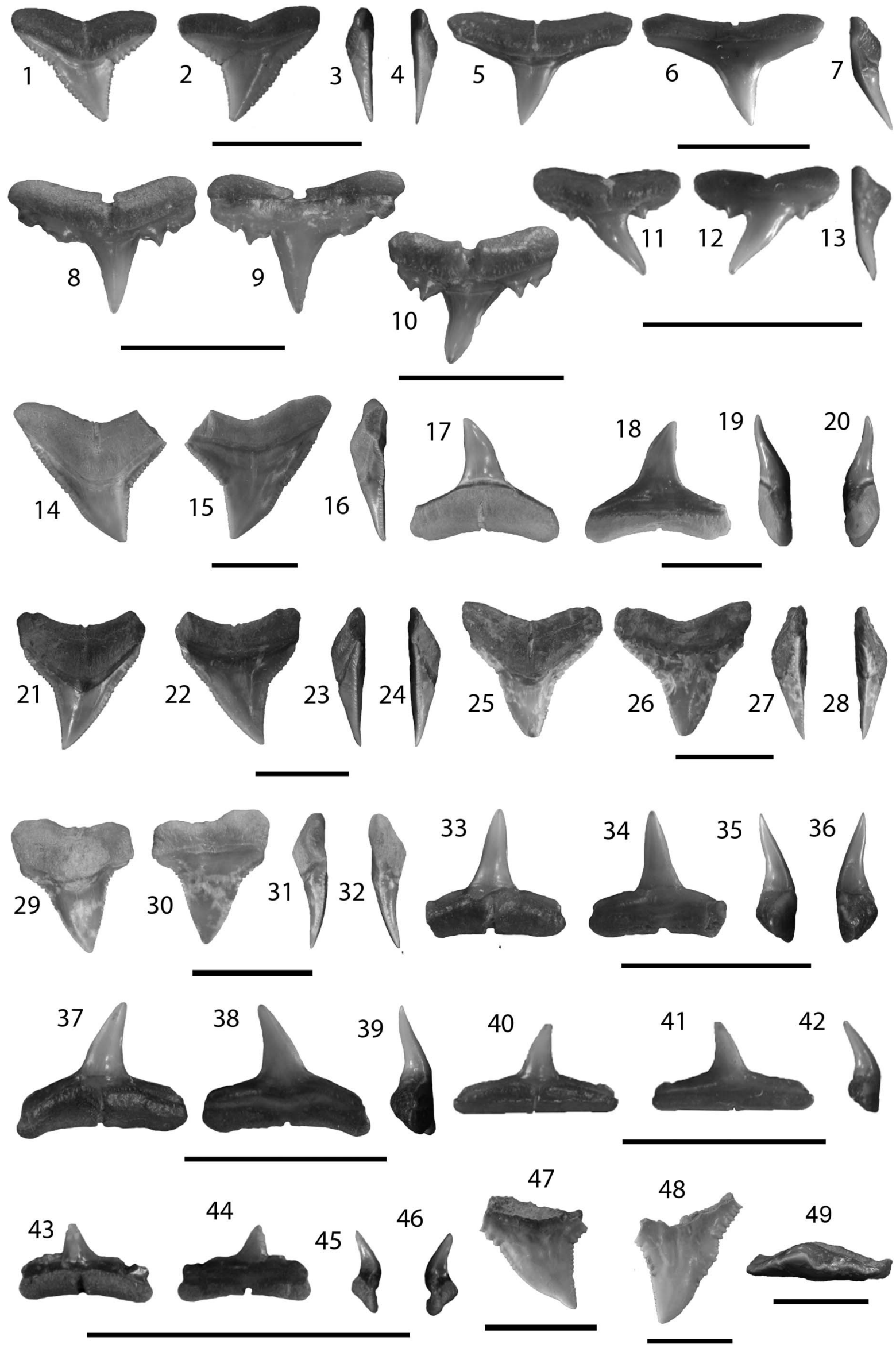
et al. (2001) only measured a single tooth with $\mathrm{CH}=14.2 \mathrm{~mm}$ and $\mathrm{CW}=15.0 \mathrm{~mm}$ that was estimated to have originated from an $\sim 3 \mathrm{~m}$ shark. The teeth from the Chucunaque Formation are more closely aligned with the size range observed from the Gatun Formation. In past descriptions of this species, a gap in the serrations on the mesial edge around the midpoint of the crown has been used as a definitive feature (Purdy et al., 2001; Pimiento et al., 2013a). However, this feature is not observed in extant individuals of Carcharhinus falciformis (Purdy et al., 2001) and, as such, should not be considered definitive. This interpretation of a gap in serrations can likely be attributed to the transition from coarse to fine serrations at the mesial notch. Extant $C$. falciformis has a circumtropical distribution and are commonly found at depths ranging from 18 to $500 \mathrm{~m}$ near the edge of continental and insular shelves, but also occur in open sea and occasionally inshore (Compagno, 1984; Compagno et al., 2005; Bonfil et al., 2009).

\section{Carcharhinus brevipinna (Müller and Henle, 1839)} Figure 6.5-6.7

Holotype.-Originally described as Carcharias (Aprion) brevipinna by Müller and Henle (1839, p. 31-32, pl. 9). The holotype is a $785 \mathrm{~mm}$ mounted skin, RMNH D2525, from Java, Indonesia that resides in Naturalis - National Natuurhistorisch Museum, Leiden, Netherlands (Compagno, 1984).

Occurrence.-STRI 290109, STRI 290113, STRI 290116, STRI 300029, STRI 300032, STRI 430011, STRI 430012, and YPA105.

Description.-Small, triangular teeth; slender, finely serrated crown that is often inclined lingually, with straight mesial and distal cutting edges. The lingual face is convex and the labial face is flat apically and convex basally, forming a ridge along the crown-root margin. The root is short with a nutrient groove and horizontal basal margin. Differentiating between upper and lower teeth is difficult, however in extant individuals upper teeth are often slightly broader (personal observation, V.J. Perez, 2015). Carcharhinus brevipinna from the Chucunaque Formation range from $\mathrm{CH}=2.7-8.6 \mathrm{~mm}$ and $\mathrm{CW}=5.4-13.2 \mathrm{~mm}$.

Materials.-One hundred forty-seven isolated teeth; lower: UF 281159; indeterminate position: UF 275041, UF 275070, UF 281153-58, and UF 281322.
Remarks.-Carcharhinus brevipinna is a relatively common species; however, its range and abundance are difficult to surmise given the constant confusion with the closely related species, Carcharhinus limbatus (Burgess, 2009). The two differ in that $C$. brevipinna has a shorter, slightly more asymmetric crown than $C$. limbatus. Also, upper teeth of $C$. limbatus typically have coarser serrations on the shoulders, particularly on the distal heel. Naylor (1990) conducted a principal component analysis to determine if upper teeth of these two species could be distinguished when monognathic variation was removed (i.e., could isolated upper teeth of these two species be distinguished from one another). The statistical analysis found that the two do in fact form distinct clusters, suggesting that isolated upper teeth can be identified to the species level. However, teeth belonging to $C$. brevipinna formed two sub-clusters that separated juveniles from adults, implying that ontogenetic variability could still pose a problem in identifying $C$. brevipinna. Neither $C$. brevipinna nor $C$. limbatus have been identified from the fossil record of Panama. Aguilera et al. (2011) did not recognize C. brevipinna from any Neogene locality from the Caribbean Neotropics, and only recognized C. limbatus from Venezuela. Carillo-Briceño et al. (2015b) identified two upper lateral teeth of $C$. limbatus from the middle-late Miocene Urumaco Formation in Venezuela. Carcharhinus brevipinna typically occurs on continental and insular shelves at depths of $0-100 \mathrm{~m}$ in warm temperate to tropical waters in the Atlantic, Mediterranean, and Indo-West Pacific (Compagno, 1984; Reiner, 1996; Burgess, 2009).

Carcharhinus aff. C. macloti (Müller and Henle, 1839) Figure 6.8-6.13

Holotype.-Originally described as Carcharias (Hypoprion) macloti by Müller and Henle (1839, p. 34, pl. 10). The holotype is an adult male from New Guinea deposited in Rijksmuseum van Natuurlijke Historie, Leiden (Compagno, 1984).

Occurrence.-STRI 290109, STRI 290113, STRI 290145, STRI 300032, and YPA105.

Description.-The crown is small with complete cutting edges that lack serrations; however the heels are equipped with distinct lateral cusplets. On the labial face, the enamel extends well onto the root. The robust root is bilaterally symmetrical with a nutrient groove that penetrates the horizontal basal margin. Images of Carcharhinus macloti from Purdy et al. (2001)

Figure 6. Carcharhiniformes II: Carcharhinus from the Chucunaque Formation. (1-4) Carcharhinus falciformis (Bibron, 1841 in Muller and Henle, 1839-1841), UF 281162, upper tooth in lingual, labial, distal lateral, and mesial lateral view, respectively (scale bar = 1 cm); (5-7) Carcharhinus brevipinna (Blainville, 1816), UF 281159, upper tooth in lingual, labial, and distal lateral view, respectively (scale bar = $1 \mathrm{~cm}$ ); (8-13) Carcharinus aff. C. macloti (Müller and Henle, 1839): (8, 9) UF 281323, upper anterior tooth in lingual and labial view, respectively (scale bar $=0.5 \mathrm{~cm}$ ); $(\mathbf{1 0})$ UF 281325 , upper lateral in lingual view (scale bar = 0.5 cm); (11-13) UF 275061, upper lateral tooth in lingual, labial, and mesial lateral view, respectively (scale bar = $1 \mathrm{~cm})$; (14-20) Carcharhinus obscurus (Lesueur, 1818): (14-16) UF 281147, upper tooth in lingual, labial, and distal lateral view, respectively (scale bar = $1 \mathrm{~cm})$; $(\mathbf{1 7 - 2 0})$ UF 281152, lower tooth in lingual, labial, mesial lateral, and distal lateral view, respectively (scale bar $=1 \mathrm{~cm})$; (21-24) Carcharhinus plumbeus (Nardo, 1827), UF 281143, upper tooth in lingual, labial, mesial lateral, and distal lateral view, respectively (scale bar $=1 \mathrm{~cm})$; (25-49) Carcharhinus sp.: (25-28) UF 281165, upper anterior tooth in lingual, labial, distal lateral, and mesial lateral view, respectively (scale bar $=1 \mathrm{~cm}) ;(\mathbf{2 9 - 3 2})$ UF 281348 , upper anterior tooth in lingual, labial, distal lateral, and mesial lateral view, respectively (scale bar $=1 \mathrm{~cm})$; $(\mathbf{3 3 - 3 6})$ UF 275141, lower anterior tooth in lingual, labial, distal lateral, and mesial lateral view, respectively (scale bar = 1 cm); (37-39) UF 275141, lower lateral tooth in lingual, labial, distal lateral, and mesial lateral view, respectively $(\mathrm{scale}$ bar = $1 \mathrm{~cm})$; $(\mathbf{4 0 - 4 2 )}$ UF 281164, lower posterior tooth in lingual, labial, distal lateral view, respectively (scale bar $=1 \mathrm{~cm})$; (43-46) UF 281182, lower posterior tooth in lingual, labial, mesial lateral, and distal lateral view, respectively (scale bar $=1 \mathrm{~cm}$ ); (47) UF 281402, upper pathologic tooth in lingual view; (48) UF 281167, upper pathologic tooth in lingual view (scale bar $=1 \mathrm{~cm}$ ); (49) UF 281168, upper pathologic tooth in apical view (scale bar $=1 \mathrm{~cm}$ ). Photo credit: R. Leder. 
indicate that the crown becomes increasingly more distally arched posteriorly and the root lobes diminish toward the posterior, forming a more horizontal basal margin. This heterodonty was also observed in the Chucunaque Formation (anterior tooth position, Fig. 6.8, 6.9; lateral tooth positions, Fig. 6.10-6.13). Purdy et al. (2001) noted that lower teeth of C. macloti do not bear lateral cusplets. Carcharhinus aff. C. macloti from the Chucunaque Formation range from $\mathrm{C}=4.2-6.3 \mathrm{~mm}$ and $\mathrm{CW}=4.2-6.1 \mathrm{~mm}$.

Materials.-Ten isolated teeth; upper: UF 275061, UF 281166 , UF 281185, and UF 281323-281325.

Remarks.-Carcharhinus macloti is extremely abundant from the Pungo River Formation. Purdy et al. (2001) referred to over 400 teeth in their description, with upper teeth ranging from $\mathrm{CH}=5.0-7.3 \mathrm{~mm}$ and $\mathrm{CW}=5.0-9.1 \mathrm{~mm}$. Carcharhinus aff. C. macloti is relatively uncommon in the Chucunaque Formation and has not been identified in the Gatun Formation, although this may be an artifact caused by a collection bias given the extremely small size of the teeth. According to Purdy et al. (2001), lower teeth are smaller than upper teeth, symmetrical, and lack the distinctive lateral cusplets. This description aligns well with that of Carcharhinus isodon, and may explain why $C$. isodon was not recognized from Lee Creek by Purdy et al. (2001) despite the fact that it is recognized as being present in Lee Creek (www.elasmo.com). Carcharhinus macloti has been reported from the Miocene of Peru (Lambert et al., 2010) and, tentatively, from the middle Eocene of Georgia (Hulbert et al., 1998). Mondal et al. (2009) also reported C. macloti from the Miocene of India, however the specimen imaged in their publication does not seem definitive for $C$. macloti. Garrick (1985) reported that abundance of lateral cusplets in upper teeth of extant $C$. macloti vary, but could not ascertain if the variation was attributed to sexual dimorphism or geographic variation. There is little known about extant individuals beyond that they occur in the Indo-West Pacific and Arafura Sea in inshore and offshore waters of continental and insular shelves (Compagno, 1984). Carcharhinus macloti has a demersal habit and typically occurs at depths of 0-170 m (Last and Stephens, 1994; Compagno et al., 2005).

\section{Carcharhinus obscurus (Lesueur, 1818)}

Figure 6.14-6.20

Holotype.-Originally described as Squalus obscurus by Lesueur (1818, p. 223, pl. 9). There is no holotype; however, the type locality is North America (Compagno, 1984).

Occurrence.-STRI 290109, STRI 290113, STRI 290116, STRI 290125, STRI 290145, STRI 300029, STRI 300032, STRI 430011, and STRI 430012.

Description.-Upper teeth are broad and triangular. The mesial edge is apically convex and either straight or concave basally forming a weak notch. The distal edge is significantly notched and is nearly vertical apical of the notch. Serrations are coarser basally and finer apically on both edges, and there is a distal deflection at the crown apex. The root is thick with a transverse groove and an obtusely angled basal margin. Lower teeth are narrow, have incomplete cutting edges with fine serrations that only comprise the upper third of the crown, a sigmoidal profile, and a distal deflection at the apex. Root is robust, thick, with a transverse groove and an obtusely angled basal margin. Upper teeth can be distinguished from other species of Carcharhinus by the apically convex mesial edge, the distal deflection of the apex, and the vertical distal cutting edge (Purdy et al., 2001). Carcharhinus obscurus from the Chucunaque Formation ranges from: upper $\mathrm{CH}=4.7-13.4 \mathrm{~mm}$ and $\mathrm{CW}=8.3-18.0 \mathrm{~mm}$; lower $\mathrm{CH}=5.6-10.8 \mathrm{~mm}$ and $\mathrm{CW}=6.9-15.2 \mathrm{~mm}$.

Materials.-One hundred eighty-four isolated teeth; upper: UF 275040, UF 275123, UF 275155, UF 281144-45, UF 281147; lower: UF 275039, UF 275072, UF 275087 , UF 275090, UF 275094, UF 275121, UF 281147-52; indeterminate position: UF 281146.

Remarks.-Lower teeth can be distinguished from other species of Carcharhinus and the genus Negaprion by their wider apex with a distal deflection and incomplete cutting edges with fine serrations limited to the upper third of the crown. The description of lower teeth from Carcharhinus egertoni by Kent (1994) is analogous to the description of lower Carcharhinus obscurus teeth herein. Observation of modern $C$. obscurus dentitions indicates that the lower $C$. egertoni teeth describe by Kent (1994) are synonymous with lower teeth of $C$. obscurus (personal communication, G. Hubbell, 2015). Carcharhinus obscurus is the most abundant species identified from the Chucunaque Formation, but is relatively uncommon in the Gatun Formation (Pimiento et al., 2013a). In the middle Miocene Grand Bay Formation of Carriacou, C. obscurus outnumbers other species by more than three to one (Portell et al., 2008). Carrillo-Briceño et al. (2015a) observed C. obscurus as the second most abundant species in the neritic Rio Indio facies and as a relatively uncommon species in the bathyal Piña Sandstone facies of the late Miocene Chagres Formation. Teeth from the Chucunaque Formation are larger than those from the Gatun Formation $(\mathrm{CH}=7.7-10.1 \mathrm{~mm}$ and $\mathrm{CW}=11.2-16.28 \mathrm{~mm}$; Pimiento et al., 2013a), but much smaller than the C. obscurus teeth described from the Yorktown Formation $(\mathrm{CH}=17.0-22.0 \mathrm{~mm}$ and $\mathrm{CW}=18.0-25.0 \mathrm{~mm}$; Purdy et al., 2001). Extant individuals with tooth sizes corresponding to those reported from the Yorktown Formation are about $3 \mathrm{~m}$ TL (Purdy et al., 2001), which suggests that $C$. obscurus from the younger Chucunaque Formation were smaller. Carcharhinus obscurus has a cosmopolitan distribution in the modern tropical and warm temperate seas, commonly occurring on continental and insular shelves, inshore and in oceanic waters (Compagno, 1984; Compagno et al., 2005). Adults most commonly occur at depths of $200-400 \mathrm{~m}$, while younger individuals can be found in shallower nursery areas (Compagno, 1984; Bass et al., 1986; Compagno et al., 2005).

\section{Carcharhinus plumbeus (Nardo, 1827)}

Figure 6.21-6.24

Holotype.-Originally described as Squalus plumbeus by Nardo (1827, p. 477). There is no holotype; however, the type locality is the Adriatic Sea (Compagno, 1984). 
Occurrence.-STRI 300032 and STRI 430011.

Description.-Upper teeth have a moderately broad crown; the mesial edge is straight with relatively uniform, moderately sized serrations and the distal edge is concave with finer serrations apically. There is no notch on either cutting edge, the lingual face is convex, and the labial face is flat. The root is thick with a transverse groove and obtusely angled basal margin. Carcharhinus plumbeus from the Chucunaque Formation ranges from $\mathrm{CH}=5.8-11.9 \mathrm{~mm}$ and $\mathrm{CW}=8.1-14.5 \mathrm{~mm}$.

Materials.—Eight isolated teeth; upper: UF 281141-43.

Remarks.-Carcharhinus plumbeus can be distinguished from other species of Carcharhinus by its straight mesial edge with fairly uniform serrations and moderate width; C. obscurus is broader and C. perezi is narrower (Purdy et al., 2001). Carcharhinus plumbeus is relatively uncommon in the Chucunaque Formation $(\mathrm{N}=8)$, the Gatun Formation $(\mathrm{N}=5$; Pimiento et al., 2013a), and the Pungo River Formation ( $\mathrm{N}=6$; Purdy et al., 2001). Carcharhinus plumbeus is intermediary in size between specimens from the Gatun Formation $(\mathrm{CH}=6.8$ $10.6 \mathrm{~mm}$ and $\mathrm{CW}=10.3-16.1 \mathrm{~mm}$; Pimiento et al., 2013a) and the Pungo River Formation $(\mathrm{CH}=14.0-19.0 \mathrm{~mm}$; Purdy et al., 2001), but more closely aligned with the individuals from the Gatun Formation. The teeth from the Pungo River Formation correspond to $\mathrm{TL}=2 \mathrm{~m}$ (Purdy et al., 2001), indicating smaller individuals in both the Chucunaque and Gatun Formations. In the bathyal Piña Sandstone facies $C$. plumbeus represents $\sim 3 \%$ of the chondrichthyan fauna, but is not observed in the neritic Rio Indio facies of the Chagres Formation (CarrilloBriceño et al., 2015a). Carcharhinus plumbeus have also been recognized in the Miocene deposits of Venezuela and Cuba (Iturralde-Vinent et al., 1996; Aguilera and Rodrigues de Aguilera, 2001; MacPhee et al., 2003). Extant individuals are benthopelagic, commonly found inshore and offshore on continental and insular shelves and adjacent deep water (Compagno, 1984). Carcharhinus plumbeus occurs at depths less than $280 \mathrm{~m}$, but are most commonly found in the range of 20-55 m (Compagno, 1984; Compagno et al., 2005).

Carcharhinus spp.

Figures 3.20, 3.21, 6.25-6.49

Occurrence.-STRI 290109, STRI 290113, STRI 290116, STRI 290145, STRI 300029, STRI 300032, STRI 430011, STRI 430012, and YPA105.

Description.-Teeth range from small to moderate size. Upper teeth are broad and triangular with serrated edges, have a flat labial face and convex lingual face. Teeth become increasingly asymmetric in lateroposterior positions. The root has a transverse nutrient groove or a nutrient pore, convex crown-root margin on the lingual face, and an arciform basal margin. Lower teeth are symmetrical with a tall, narrow crown and complete cutting edges. The root is thick with two prominent lobes and a transverse groove; the basal margin may be near horizontal or arcuate.
Materials.-Four hundred twenty-seven isolated teeth; upper anterior: UF 281165, UF 281328, UF 281331-32, UF 281335 , UF 281344, UF 281346, UF 281348; upper: UF 275038, UF 275140, UF 281167, UF 281327, UF 281334, UF 281339, UF 281343, UF 281345; upper pathologic: UF 281168, UF 281338, UF 281347, UF 281402; lower: UF 275035, UF 275042, UF 275063, UF 275074, UF 275076, UF 275081, UF 275089, UF 275141, UF 275143, UF 275154, UF 281163 , UF 281164, UF 281326, UF 281330, UF 281333, UF 281337 , UF 281340, UF 281342, UF 281403; posterior: UF 281182-83, UF 281361-63, UF 281269; indeterminate position: UF 275034, UF 275036, UF 275067, UF 275077, UF 275079, UF 275088, UF 275101, UF 275119, UF 275149, UF 281329, UF 281336, and UF 281341.

Remarks.-The genus Carcharhinus is the most abundant among the chondrichthyans from the Chucunaque Formation. There is much debate regarding the assignment of teeth from this genus to the species level (Naylor and Marcus, 1994; Purdy et al., 2001; Pimiento et al., 2013a), especially in the case of lower teeth (Kent, 1994). Lower teeth are very similar to Negaprion brevirostris, but can be distinguished by having a shorter crown. This confusion can be attributed to the convergent dignathic heterodonty expressed by this genus, in which the lower jaw has a grasping function and the upper jaw has a cutting function. Naylor and Marcus (1994) determined that upper lateral teeth are the most diagnostic teeth within the dentition and can accurately be identified to the species level. Pimiento et al. (2013a) reported tooth sizes ranging from $\mathrm{CH}=1.9-12.9 \mathrm{~mm}$ and $\mathrm{CW}=4.1-$ $17.6 \mathrm{~mm}$, which is much smaller than the maximum $\mathrm{CH}$ of $20 \mathrm{~mm}$ observed by Cappetta (1987). Four upper teeth from the Chucunaque Formation exhibit distinct pathologies (Figs. 3.20, 3.21, 6.47-6.49), represented by two morphotypes. The first pathologic morphotype is a lack of serrations on one cutting edge near the crown apex (Figs. 3.20, 3.21, 6.48) and the second morphotype is a disruption of the cutting edge indicated by a wrinkled pattern (Fig. 6.47, 6.49). The cause of these pathologies is unclear, however, most tooth deformities are often attributed to feeding damage related to bones or tail spines getting lodged into the jaw (Gudger, 1937). Carcharhinus spp. are the most abundant sharks in shallow, nearshore environments, with at least 30 known living species (Kent, 1994; Naylor and Marcus, 1994). This genus has a widespread distribution, occurring in all temperate and tropical seas (Cappetta, 1987), and can most commonly be found in coastal waters (Compagno, 1984).

Genus Negaprion Whitley, 1940

Type.-Aprionodon acutidens subsp. queenslandicus Whitley, 1939 (Cappetta, 2012).

\section{Negaprion brevirostris (Poey, 1868)}

Figure 7.1-7.4

Holotype.-Originally described as Hypoprion brevirostris by Poey $(1868$, p. 451 , pl. 4 , figs. 5, 6, 20). The holotype is unknown; however, the type locality is Cuba (Compagno, 1984). 

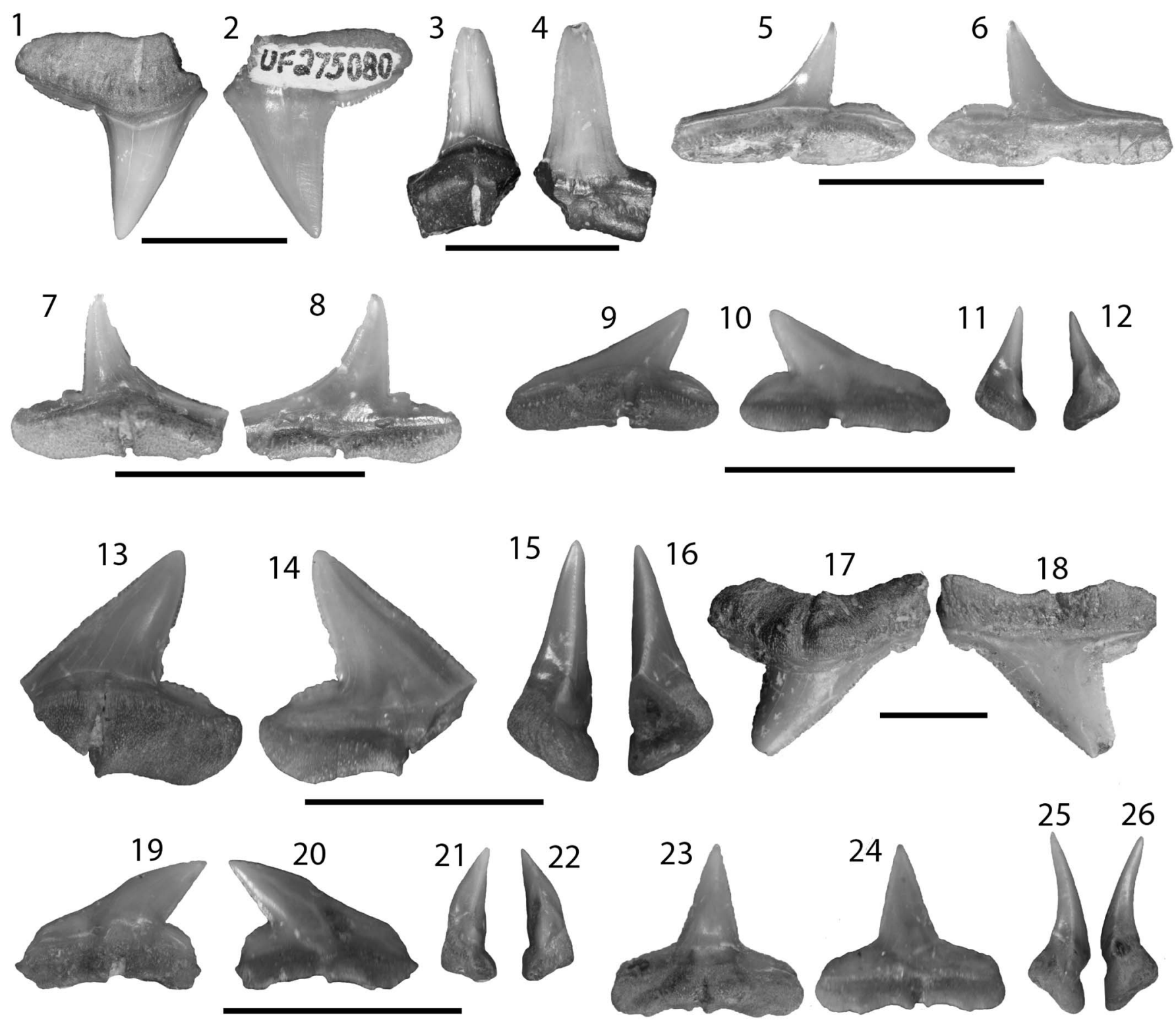

Figure 7. Carcharhiniformes III: Negaprion, Rhizoprionodon, and Sphyrna from the Chucunaque Formation. (1-4) Negaprion brevirostris (Poey, 1868), scale bar $=1 \mathrm{~cm}$ : $(\mathbf{1}, \mathbf{2})$ UF 275080 , upper left lateral tooth in lingual and labial view, respectively; $(\mathbf{3}, \mathbf{4})$ UF 275080 , lower tooth in lingual and labial view, respectively; (5-8) Rhizoprionodon sp., scale bar $=0.5 \mathrm{~cm}:(\mathbf{5 , 6})$ UF 322848, indeterminate position in lingual and labial view, respectively; $(\mathbf{7 , 8})$ UF 322849 , indeterminate position in lingual and labial view, respectively; (9-12) Sphyrna lewini (Griffith and Smith, 1834), UF 281176, upper position in lingual, labial, mesial lateral, and distal lateral view, respectively (scale bar = $1 \mathrm{~cm}$ ); (13-18) Sphyrna mokarran (Ruppell, 1837): (13-16) UF 275043, upper position in lingual, labial, mesial lateral, and distal lateral view, respectively, (scale bar $=1 \mathrm{~cm}) ;(\mathbf{1 7}, \mathbf{1 8})$ UF 275066, upper lateral tooth in lingual and labial view, respectively (scale Bar = 0.5 cm); (19-26) Sphyrna zygaena, scale bar $=1 \mathrm{~cm}:(\mathbf{1 9 - 2 2})$ UF 275073 , upper lateral tooth in lingual, labial, mesial lateral, and distal lateral view, respectively; (23-26) UF 275073, lower anterior tooth in lingual, labial, distal lateral, and mesial lateral view, respectively. Photo credit: R. Leder.

\section{Occurrence.-STRI 290116 and STRI 430012.}

Description.-Tall, narrow crown, with a convex lingual face and flat labial face that extends onto the root. The cutting edges are complete and extend onto the heels, and may or may not bear serrations. Root is moderately thick with a weak transverse groove. Lateral teeth tend to bear a distal inclination and subsequently exhibit increasing asymmetry. A distinct dignathic heterodonty exists, with upper teeth having a broader crown than lower teeth. Negaprion brevirostris from Lago Bayano range from $\mathrm{CH}=7.7-11.6 \mathrm{~mm}$ and $\mathrm{CW}=4.8-16.1 \mathrm{~mm}$.
Materials.-Three isolated teeth; upper: UF 275080; lower: UF 275150.

Remarks.-In the Miocene, this species has been identified as an extinct species, Negaprion eurybathrodon (Cappetta, 1987; Kent, 1994; Purdy et al., 2001); however Pimiento et al. (2013a) recognized that the Miocene morphotype is analogous to the extant species, Negaprion brevirostris, and aptly reassigned it to $N$. brevirostris. Purdy et al. (2001) reported anterolateral teeth of $N$. eurybathrodon ( $=N$. brevirostris) from Lee Creek ranging from $\mathrm{CH}=14.0-21.0 \mathrm{~mm}$, corresponding to a mature adult 
body size range of $\mathrm{TL}=2.1-3 \mathrm{~m}$ (Compagno, 1984). Teeth from the Chucunaque Formation and the Gatun Formation $(\mathrm{CH}=3.7-13.7 \mathrm{~mm}$; Pimiento et al., 2013a) are smaller than those of Lee Creek. Negaprion brevirostris has been identified in the Miocene of Venezuela, Cuba, and Ecuador (Longbottom, 1979; Iturralde-Vinent et al., 1996; Aguilera and Rodrigues de Aguilera, 2001; MacPhee et al., 2003). Carrillo-Briceño et al. (2015a) reported two teeth attributed to $N$. brevirostris from the neritic Rio Indio facies, but no occurrences in the bathyal Piña Sandstone facies of the Chagres Formation. Extant individuals occur in tropical and temperate, estuarine and marine waters generally at depths of 0-92 m (Compagno, 1984; Kent, 1994). Negaprion brevirostris frequents mangrove fringes and coral reefs, but occasionally can be found in open ocean near surface waters for migration purposes (Compagno, 1984; Compagno et al., 2005).

Genus Rhizoprionodon Whitley, 1929

Type.-Carcharias (Scoliodon) crenidens Klunzinger, 1880 (Cappetta, 2012).

Rhizoprionodon sp.

Figure 7.5-7.8

Occurrence.-STRI 290109, STRI 290116, and YPA105.

Description.-Small teeth with a short, slender crown; complete cutting edges; and a recurved mesial edge and straight to convex distal edge forming a distinct notch with a rounded distal heel. The root is thin with a deep transverse groove that penetrates a horizontal basal margin. Rhizoprionodon sp. from the Chucunaque Formation range from $\mathrm{CH}=1.9-2.4 \mathrm{~mm}$ and $\mathrm{CW}=4.1-5.1 \mathrm{~mm}$.

Materials.-Fifty-five isolated teeth; indeterminate position: UF 275091, UF 281364-281268, and UF 281370.

Remarks.-Much confusion remains regarding the identification of Rhizoprionodon teeth, due to the closely aligned teeth of Sphyrna and, possibly synonymous, teeth of Scoliodon and Loxodon that were established by Springer (1964). Rhizoprionodon sp. differs from Sphyrna lewini in having a shorter crown, recurved mesial edge, and less pronounced root. Rhizoprionodon sp. differs in proportional size relative to Sphyrna, with Sphyrna having a greater crown height to width ratio (Purdy et al., 2001). Cappetta (1987) mentioned a marked sexual dimorphism in Rhizoprionodon, but it is possible that fossil specimens described may actually represent the morphologically similar Scoliodon and/or Loxodon. Consequently, identification of teeth from this genus should be treated with some degree of skepticism. Cappetta (1987) states that Rhizoprionodon teeth do not exceed $\mathrm{CH}=4 \mathrm{~mm}$; however, Purdy et al. (2001) reported a range from $\mathrm{CH}=3.2-5.2 \mathrm{~mm}$ and $\mathrm{CW}=4.3-5.7 \mathrm{~mm}$. Teeth of the Gatun Formation $(\mathrm{CH}=2.5$ $3.3 \mathrm{~mm}$ and $\mathrm{CW}=3.9-5.6 \mathrm{~mm}$; Pimiento et al., 2013a) are more closely aligned with those of the Chucunaque Formation. Rhizoprionodon previously has been reported from the middle and late Miocene of France, Belgium, and Portugal (Cappetta, 1987). Carrillo-Briceño et al. (2015a) noted Rhizoprionodon as a small component ( $4 \% ; \mathrm{N}=20)$ of the bathyal Piña Sandstone facies, but no occurrences in the neritic Rio Indio facies of the Chagres Formation. Extant individuals can be found worldwide in shallow, nearshore tropical and temperate waters (Compagno, 1984; Kent, 1994). Rhizoprionodon terraenovae occurs at depths ranging from the intertidal zone to $280 \mathrm{~m}$, but usually occur at depths less than $10 \mathrm{~m}$ (Compagno, 1984; Compagno et al., 2005).

Family Sphyrnidae Gill, 1872

Genus Sphyrna Rafinesque, 1810

Type.—Squalus zygaena Linnaeus, 1758 (Cappetta, 2012).

Sphyrna lewini (Griffith and Smith, 1834)

Figure 7.9-7.12

Holotype.-Originally described as Zygaena lewini by Griffith and Smith (1834 in Cuvier, Griffith, and Smith, 1834, p. 640, pl. 50). Holotype information is unknown, however the type locality is the south coast of New Holland (Australia) (Compagno, 1984).

Occurrence.-STRI 290109, STRI 290113, STRI 290125, and STRI 290145.

Description.-Small teeth with a stout to slender, distally inclined crown and prominent distal heel. Cutting edges are complete and lack serrations; the mesial edge is straight to slightly concave and the distal edge is straight and inclined forming a deep notch. The distal heel is rounded and has an unserrated cutting edge. The root is thick with a deep nutrient groove that penetrates a horizontal basal margin. Sphyrna lewini from the Chucunaque Formation ranges from $\mathrm{CH}=2.0-4.6 \mathrm{~mm}$ and $\mathrm{CW}=4.9-7.5 \mathrm{~mm}$.

Materials.-Thirteen isolated teeth; upper: UF 281176; indeterminate position: UF 275048, UF 275050, UF 275075, UF 275106, and UF 275153.

Remarks.-Sphyrna lewini differs from Rhizoprionodon in having a straighter mesial edge, taller crown, and thicker root. Sphyrna lewini specimens from the Chucunaque Formation are smaller than those recorded from the Gatun Formation $(\mathrm{CH}=$ 2.7-5.4 mm and CW $=5.2-11.0 \mathrm{~mm}$; Pimiento et al., 2013a) and the Yorktown Formation $(\mathrm{CH}=7.3-7.8 \mathrm{~mm}$ and $\mathrm{CW}=$ 6.5-9.6 mm; Purdy et al., 2001). However, it is possible that some of the larger teeth identified as Sphyrna zygaena actually represent S. lewini, which would result in a more comparable size range. Sphyrna lewini has also been reported from the late Miocene Chagres Formation of Panama (Carrillo-Briceño et al., 2015a) and the Miocene of Cuba (Iturralde-Vinent et al., 1996; MacPhee et al., 2003). Extant Sphyrna lewini have a circumglobal distribution in warm temperate and tropical seas, occurring over continental and insular shelves and adjacent deep water less than $\sim 275 \mathrm{~m}$ depth (Compagno, 1984; Compagno et al., 2005). Large schools of small individuals have been observed migrating poleward in the summer, however permanent resident populations also exist (Compagno, 1984).

Sphyrna mokarran (Ruppell, 1837)

Figure 7.13-7.18 
Holotype.-Originally described as Zygaena mokarran by Ruppell (1837, p. 64, pl. 18, fig. 1). According to Klausewitz (1960), a $2515 \mathrm{~mm}$ stuffed male from Massaua, Red Sea, SMB 3590, serves as a lectotype in Naturmuseums Senckenberg (Compagno, 1984).

\section{Occurrence.—STRI 290109 and STRI 300032.}

Description.-Moderately large teeth with a broad, serrated crown; straight or convex mesial edge and straight distal edge with a distal inclination that forms a deep notch; and a prominent distal heel that is rounded and serrated. The root is robust with a deep nutrient groove that penetrates a horizontal basal margin. Sphyrna mokarran from the Chucunaque Formation ranges from $\mathrm{CH}=6.6-9.8 \mathrm{~mm}$ and $\mathrm{CW}=9.3-14.7 \mathrm{~mm}$.

Materials.-Four isolated teeth; upper: UF 275043, UF 275066, and UF 281184.

Remarks.-Sphyrna mokarran is easily distinguished from other species of Sphyrna by its larger size and regular serrations. Pimiento et al. (2013a) noted the paucity of documented occurrences of Sphyrna mokarran in the fossil record, mentioning that in the Neotropics it has only been reported from the Miocene of Cuba without any description of the specimens (MacPhee et al., 2003). Teeth from the Chucunaque Formation are comparable in size to those found in the Gatun Formation $(\mathrm{CH}=7.6-9.4 \mathrm{~mm}$ and $\mathrm{CW}=9.6-16.4 \mathrm{~mm}$; Pimiento et al., 2013a). Extant individuals reach a maximum $\mathrm{TL}=6.1 \mathrm{~m}$ and have a circumtropical distribution, occurring close inshore and well offshore (Compagno, 1984). Sphyrna mokarran most commonly populates bottom and reef associated waters in a depth range of 1-80 m (Compagno, 1984; Compagno et al., 2005).

\section{Sphyrna zygaena (Linnaeus, 1758)}

Figure 7.19-7.26

Holotype.-Originally described as Squalus zygaena by Linnaeus (1758, p. 234); however, Compagno (1984) does not acknowledge a holotype.

Syntype.-Naturhistoriska Riksmuseet, Department of Vertebrate Zoology, Ichthyology Section, Stockholm, Sweden, NRM 88, $215 \mathrm{~mm}$ specimen.

Occurrence.-STRI 290109, STRI 300032, STRI 430011, STRI 430012, and YPA105.

Description.-Moderately broad, labio-lingually flattened crown; convex to sigmoidal mesial edge and straight to concave distal edge. There is a distal inclination forming an acute notch with a rounded distal heel. The cutting edges and heel may or may not bear weak serrations. The root is thick with a transverse groove that penetrates a horizontal basal margin. Anterior teeth are more erect and lack the acute distal notch. Sphyrna zygaena from the Chucunaque Formation range from $\mathrm{CH}=2.6-8.1 \mathrm{~mm}$ and $\mathrm{CW}=4.8-9.6 \mathrm{~mm}$.
Materials.-Ninety-six isolated teeth; indeterminate position: UF 275044, UF 275058, UF 275073, UF 275142, UF 281175 , and UF 281371-73.

Remarks.-Sphyrna zygaena tend to have thicker, broader crowns and a more sigmoid mesial edge than Sphyrna lewini; however, the differences between the two species are sparse, especially in smaller individuals of S. zygaena. Compagno (1988) noted that there is weak ontogenetic heterodonty in the genus Sphyrna. In juveniles and young adults of the extant S. zygaena, teeth have smooth cutting edges, but larger individuals become weakly serrate (Gilbert, 1967). Gillette (1984) originally identified $S$. zygaena from the Gatun Formation, however Pimiento et al. (2013a) reassigned these teeth to $S$. lewini $(\mathrm{CH}=2.7-5.4 \mathrm{~mm}$ and $\mathrm{CW}=5.2-11.0 \mathrm{~mm})$ and Sphyrna $\mathrm{sp}$. $(\mathrm{CH}=3.1-8.9 \mathrm{~mm}$ and $\mathrm{CW}=7.4-10.6 \mathrm{~mm})$. Purdy et al. (2001) reported teeth from the Pungo River Formation occurring in a size range of $\mathrm{CH}=8.0-11.0 \mathrm{~mm}$, which corresponds with the larger teeth identified as $S$. zygaena from the Chucunaque Formation. Teeth from all three formations are much smaller than the upper limit of $20 \mathrm{~mm}$ reported by Cappetta (1987). Extant Sphyrna zygaena inhabit all temperate and tropical seas, and most commonly occur in coastal waters over continental shelves from depths of 0-200 m (Compagno et al., 1989); however, it has been proposed that the distribution of $S$. zygaena in tropical environments is incompletely known due to probable confusion with S. lewini (Casper et al., 2005).

\section{Order Carcharhiniformes incertae sedis} Figure 8.1-8.11

\section{Occurrence.-STRI 290139, STRI 290145, and YPA105.}

Description.-Scyliorhiniod-type (Tessman, 1966) vertebral centra with smooth dorsoventral edges and two sets of paired foramina; the caudal and cranial faces are concave with a circular to oval-shaped outline and distinct annuli, except in the smallest specimen (UF 281399). In lateral view, the centra have a cylindrical, disk-like to hourglass shape. Posterior vertebrae are more compressed than anterior positions (Kent, 1994). The shape of the dorsal and ventral foramina, the presence or absence of septa, and the distribution of vertebral pores are diagnostic characteristics for identifying different genera (Kent, 1994; Purdy et al., 2001). These centra can confidently be assigned to the order Carcharhiniformes because they lack the septate dorsoventral walls diagnostic for Lamniformes; however, they lack features that would allot for more specific identification. These centra range from a dorsoventral diameter of $1.27-33.56 \mathrm{~mm}$ and a wall length of $0.87-14.38 \mathrm{~mm}$.

Materials.-Four isolated vertebrae; indeterminate position: UF 281195-96 and UF 281399-400.

Remarks.-Post-cranial elements are rare for chondrichthyan taxa. Typically the only non-dental remains recovered are vertebral centra because they are more densely calcified than the rest of the cartilaginous skeleton (Kent, 1994). However, the morphologic variability in vertebral centra is more conservative than that of teeth, making it difficult to identify isolated 

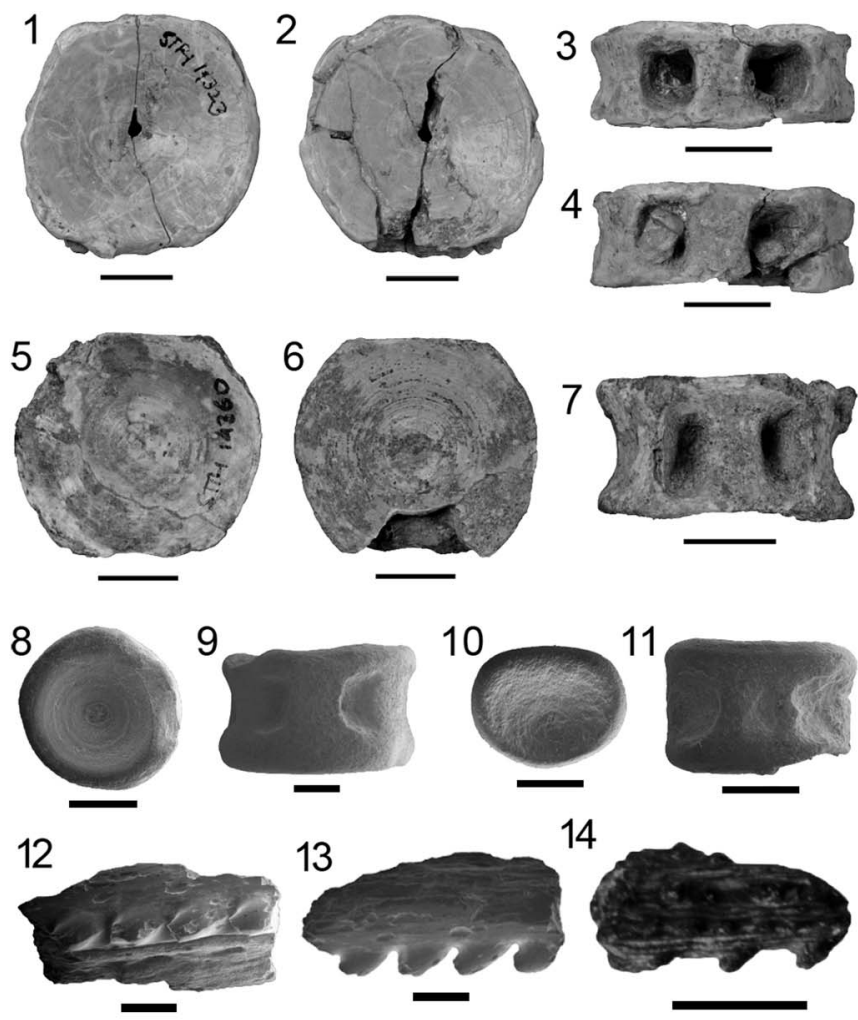

14
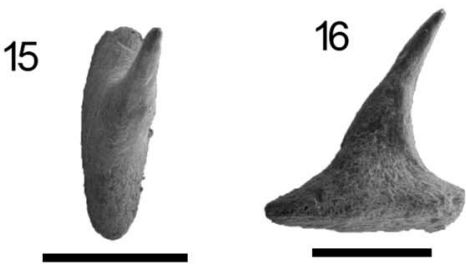

Figure 8. Non-dental elements from the Chucunaque Formation (1-11) Carcharhiniform centra: (1-4) UF 281195, posterior, anterior, ventral, and dorsal view, respectively (scale bar $=1 \mathrm{~cm}) ;(5-7)$ UF 281196 , anterior, posterior, and dorsal view, respectively (scale bar $=1 \mathrm{~cm}$ ); (8, 9) UF 281400: (8) indeterminate anterior-posterior face (scale bar $=200 \mu \mathrm{m}$ ); (9) indeterminate dorsal-ventral face $($ scale $b a r=100 \mu \mathrm{m}) ;(\mathbf{1 0}, \mathbf{1 1})$ UF 281399, indeterminate anterior-posterior face and indeterminate dorsal-ventral face, respectively (scale bar $=100 \mu \mathrm{m})$. (12-14) Myliobatiformes incertae sedis: $(\mathbf{1 2}, \mathbf{1 3})$ UF 281317 , caudal spine in lateral and dorsal view, respectively (scale bar $=1 \mathrm{~mm}$ ); (14) UF 281499, caudal spine in dorsal view (scale bar $=1 \mathrm{~mm}$ ); $(\mathbf{1 5}, \mathbf{1 6})$ Batomorphii incertae sedis, UF 281401, dermal denticle in apical and lateral view, respectively $($ scale bar $=1 \mathrm{~mm})$. Photo credit: $\mathrm{S}$. Moran.

specimens to genus or species. Purdy et al. (2001) identified vertebrae of Hemipristis serra, Galeocerdo cf. G. cuvier, and Carcharhinus spp. based on dispersal of nutrient pores and the shape of dorsal and ventral foramen. Vertebrae from the Chucunaque Formation lack characteristics to warrant identification beyond Carcharhiniformes, in part because of their preservation, but mostly due to their inherent non-descript nature. Chondrichthyan vertebral centra have been recovered from the Eocene Tonosi Formation (Vasquez and Pimiento, 2014) and the early Miocene Culebra Formation (Pimiento et al., 2013b) of Panama. The four centra described here are the first chondrichthyan vertebral elements described from the late Miocene of Panama. Despite their lack of taxonomic information, vertebral centra can provide a lot of information about the individual from which they originated and the environment in which they resided. Vertebral centra have coupled growth bands, in which light bands represent growth during cold seasons and dark bands represent growth during warm seasons (Calliet et al., 1985, 1986, 2006; Calliet and Goldman, 2004).

Subdivision Batoidea Compagno, 1973

Order Rajiformes Berg, 1940

Family Rhynchobatidae Garman, 1913

Genus Rhynchobatus Müller and Henle, 1837

Type.-Rhinobatus laevis Bloch and Schneider, 1801 (Cappetta, 2012).

\section{Rhynchobatus sp.}

Figure 9.1-9.3

\section{Occurrence.-STRI 290116.}

Description.-In apical view, the crown is convex with a transverse crest dividing the lingual and labial faces. On the labial face, the crown is downward sloping with a well-defined uvula and secondary keel; there are foramina on the mesial and distal edges of the root. The lingual face is smooth with a high root that forms a distinct ridge at the crown-root contact; there is a prominent medial groove, with a foramen, that divides the root and lateral lobes on both the mesial and distal edges, giving the root a trilobate form (Pimiento et al., 2013a). The dimensions of this specimen are a $\mathrm{CW}=4.17 \mathrm{~mm}, \mathrm{a} \mathrm{CL}=2.48 \mathrm{~mm}$, and $\mathrm{a} \mathrm{CH}=3.64 \mathrm{~mm}$.

Materials.-One isolated tooth; indeterminate position: UF 281314.

Remarks.-The dimensions of this tooth are much larger than those reported from the Gatun Formation (length $=0.9 \mathrm{~mm}$, width $=0.9 \mathrm{~mm}$; Pimiento et al., 2013a); however Compagno (1987) reported a CW of up to $5 \mathrm{~mm}$ for Rhynchobatus. Aguilera and Rodrigues de Aguilera (2001) documented this genus from the Miocene of Venezuela. There are six extant species of Rhynchobatus that occur in the tropical and subtropical IndoPacific and a single species in the eastern Atlantic, R. luebberti (Compagno and Marshall, 2006). Rhynchobatus luebberti is a benthic species often occurring in the intertidal zone, from 0-70 $\mathrm{m}$ depth, but most commonly found in less than $35 \mathrm{~m}$ depth (Compagno and Marshall, 2006). Rhynchobatus djiddensis is a reef-associated species that occurs inshore and in shallow estuaries, generally between 2 and $50 \mathrm{~m}$ depth (Sommer et al., 1996).

Order Myliobatiformes Compagno, 1973

Family Urotrygonidae McEachran et al., 1996 Genus Urobatis Garman, 1913

Type.—Raja (Leiobatus) sloani Garman, 1913 (Cappetta, 2012).

Urobatis sp.

Figure 9.4-9.6

\section{Occurrence.-YPA105.}

Description.-In apical view, the crown has an elliptical to nearly hexagonal outline with a reticulate ornamentation, a transverse depression, and a significant lingual protuberance. 

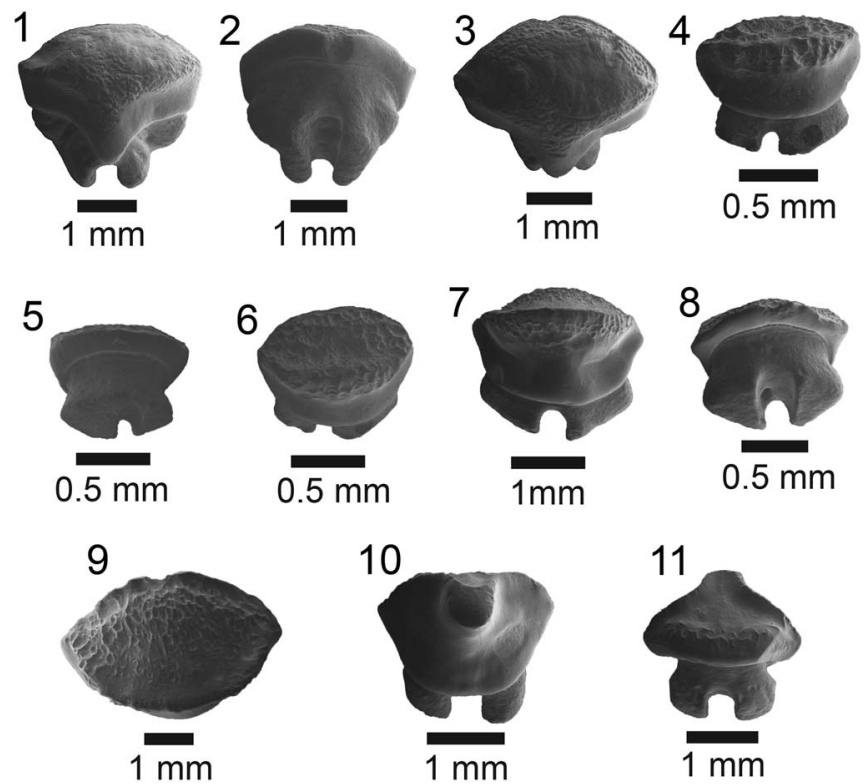

Figure 9. Batoid I: Rhynchobatus, Urobatis, and Dasyatis SEM images from the Chucunaque Formation. (1-3) Rhynchobatus sp., UF 281314 indeterminate position in apico-lingual, baso-labial, and occlusal view, respectively; (4-6) Urobatis sp., UF 281316, indeterminate female tooth in lingual, baso-labial, and occlusal view, respectively; (7-11) Dasyatis sp.: (7-9) UF 281233, indeterminate female tooth in apico-lingual, baso-labial, and occlusal view, respectively; $(\mathbf{1 0}, \mathbf{1 1})$ UF 281237, indeterminate male tooth in apico-lingual and labial view, respectively.

The lingual face is smooth and overhangs the root. There is a shallow depression at the crown-root contact that forms a distinct ridge. The root is divided by a medial groove that forms two prominent root lobes with flat bases; in lingual view the right lobe is significantly larger, indicating a lateral position. The flat, lozenge-shaped crown is a diagnostic feature of a female (Cappetta, 2012; Pimiento et al., 2013a). The imaged specimen (Fig. 9.4-9.6) has a $\mathrm{CL}=0.63 \mathrm{~mm}$ and a $\mathrm{CW}=1.05 \mathrm{~mm}$.

Materials.-Two isolated teeth; female lateral position: UF 281315-16.

Remarks.-Urobatis sp. recognized in the Gatun Formation (Pimiento et al., 2013a) is similar to that of the Chucunaque Formation described above, however the specimen from the Gatun Formation has a smooth transverse depression on the lingual half of the crown. It is possible that they reflect two different species, or that they represent positional differences. Specimens from the Gatun Formation and the Chucunaque Formation share similarities with the extant Urobatis halleri (previously referred to as Urolophus halleri; Cappetta, 1987, 2012), which today is found in the eastern Pacific from northern California to Panama (McEachran, 1995). Urobatis halleri is a demersal species known to occur in depths of 0-91 m (Michael, 1993), but most frequently occurs at depths of 0-21 m (Love et al., 2005).
Type.-Dasyatis ujo Rafinesque, 1810 (Cappetta, 2012).

Dasyatis sp.

Figure 9.7-9.11 Occurrence.-STRI 290109, STRI 290113, STRI 290116, and
YPA105.

Description.-In apical view, female teeth have an elliptical outline with a reticulate surface and a transverse keel; the surface becomes smooth toward the lingual face and forms a completely smooth lingual uvula; the labial face overhangs well over the root forming a prominent ridge. Thick root divided into two lobes by a deep, transverse groove; there is a large foramen nested within the transverse groove; the base of the root lobes is flat with a semicircular to triangular outline. The male teeth have a higher crown with a triangular outline and a prominent cusp that is smooth and lingually oriented; the occlusal surface is fluted, forming distal and mesial crests; there is also a weak medial, labio-lingual ridge and irregular folds on the convex labial edge. The root is bipartite with rounded lobes that are divided by a deep nutrient groove. Female and male teeth differ in that the female teeth have reticulate surface with a transverse crest, no prominent cusp, and broader root lobes. Also, the occlusal surface of female teeth is somewhat rounded and convex, whereas the male teeth have a more triangular appearance (Purdy et al., 2001). The female tooth (Fig. 9.7-9.9) has a $\mathrm{CH}=1.30 \mathrm{~mm}, \mathrm{CW}=2.34 \mathrm{~mm}$, and $\mathrm{CL}=1.56 \mathrm{~mm}$. The male specimen imaged (Fig. 9.10, 9.11) has a $\mathrm{CH}=1.38 \mathrm{~mm}, \mathrm{CW}=2.33 \mathrm{~mm}$, and $\mathrm{CL}=1.63 \mathrm{~mm}$.

Materials.-Nineteen isolated teeth; three male: UF 281228, UF 281237; 14 female: UF 281229, UF 281231-36, UF 281238; two indeterminate: UF 281230.

Remarks.—Dasyatis sp. has not been identified in Panama, from either the Gatun Formation or the overlying Chagres Formation. The closest related species known from the Gatun Formation is Taeniura aff. T. grabata (Pimiento et al., 2013a), which is in the family Dasyatidae (now recognized as Taeniurops aff. $T$. grabata by Cappetta, 2012). Purdy et al. (2001) recognized three species of Dasyatis from the Lee Creek Mine: $D$. say, D. centroura, and $D$. cf. americana, however $D$. centroura is only known from dermal denticles and $D$. cf. americana is only known from a single tooth. Dasyatis say specimens from the Pungo River Formation and the Yorktown Formation range from $\mathrm{CH}=2.6-3.8 \mathrm{~mm}$ and $\mathrm{CW}=$ $2.8-3.9 \mathrm{~mm}$, which is larger than the specimens identified herein. Cappetta (1987) reported that teeth of this genus can be up to $6 \mathrm{~mm}$ wide, nearly three times as large as the teeth from the Chucunaque Formation and twice as large as the teeth described from Lee Creek. Extant species of this genus have a demersal habit and are common in subtropical to tropical waters (Compagno, 1984).

$$
\begin{gathered}
\text { Family Myliobatidae Bonaparte, } 1838 \\
\text { Genus Aetobatus Blainville, } 1816
\end{gathered}
$$

Type.-Raja narinari Euphrasen, 1790 (Cappetta, 2012).
Family Dasyatidae Jordan, 1888

Genus Dasyatis Rafinesque, 1810

\section{Aetobatus sp.}

Figure 10.1-10.3 
Occurrence.-STRI 290145 and STRI 300032.

Description.-Flat, wide teeth with a low crown, a smooth occlusal surface, and often trapezoidal outline. Labial edge is straight or convex; lingual edge straight or concave; extremities of tooth plates are oriented distally. Root is short and polyaulacorhizid with oblique, parallel root lobes. In occlusal view, the root extends beyond the crown on the labial edge.

Materials.-Six isolated tooth fragments; indeterminate position: UF 281225-26.

Remarks.-Teeth of Aetobatus sp. can be distinguished from Rhinoptera by their lower crown, rounded and distally oriented extremities, and oblique root lobes that extend beyond the crown (Laurito and Valerio, 2008). Aetobatus cf. A. narinari was reported from the Gatun Formation and was fairly common $(\mathrm{N}=22)$; however, only one specimen was a complete tooth with the following dimensions: $\mathrm{CW}=66.0 \mathrm{~mm}, \mathrm{CL}=8.0 \mathrm{~mm}$, and $\mathrm{CH}$ $=4.5 \mathrm{~mm}$ (Pimiento et al., 2013a). In contrast, Aetobatus sp. from the Chucunaque Formation is fairly uncommon $(\mathrm{N}=6)$ and no complete specimens were recovered for an accurate size comparison. Aetobatus and Rhinoptera, as well as Myliobatis and Aetomylaeus, have dental plates that are formed by numerous interlocking teeth that comprise a large crushing surface primarily used to feed on mollusks and decapods (Compagno, 1997). Extant Aetobatus narinari has a cosmopolitan distribution in subtropical and tropical seas, commonly occurring in shallow waters between 1 and $60 \mathrm{~m}$ depth (Mundy, 2005).

Family Rhinopteridae Jordan and Evermann, 1896 Genus Rhinoptera Kuhl in Cuvier, 1829

Type.-Myliobatis marginata Geoffroy Saint-Hilaire, 1809 (Cappetta, 2012).

\section{Rhinoptera sp.}

Figure 10.4-10.15

Occurrence.-STRI 290109, STRI 290116, STRI 300029, STRI 300032, and STRI 430011.

Description.-Thick, elongate teeth with a smooth occlusal surface and hexagonal outline; fragmented tooth plates often have a rectangular outline. In cross-section, the enamel is comprised of vertical prisms that radiate outward from the pulp cavity, indicating extensional growth. Labial face bears a transverse platform, which interlocks with the lingual visor of the proceeding tooth (Pimiento et al., 2013a). Symphyseal teeth interlock with smaller lateral teeth via their angular extremities (Cappetta, 1987). In lateral teeth, the crown is thicker towards the mesial edge than the distal edge. Root is polyaulacorhizid with numerous lobes, fewer lobes in the smaller lateral teeth; the root is short relative to the crown. Rhinoptera sp. from the Chucunaque Formation has a $\mathrm{CH}=1.9-4.3 \mathrm{~mm}, \mathrm{CW}=3.1-5.7 \mathrm{~mm}$, and $\mathrm{CL}=6.4-16.4 \mathrm{~mm}$.

Materials.-Thirty-eight isolated teeth; 10 complete and 18 fragments; symphyseal: 281307; lateral: UF 281227, UF 281304,
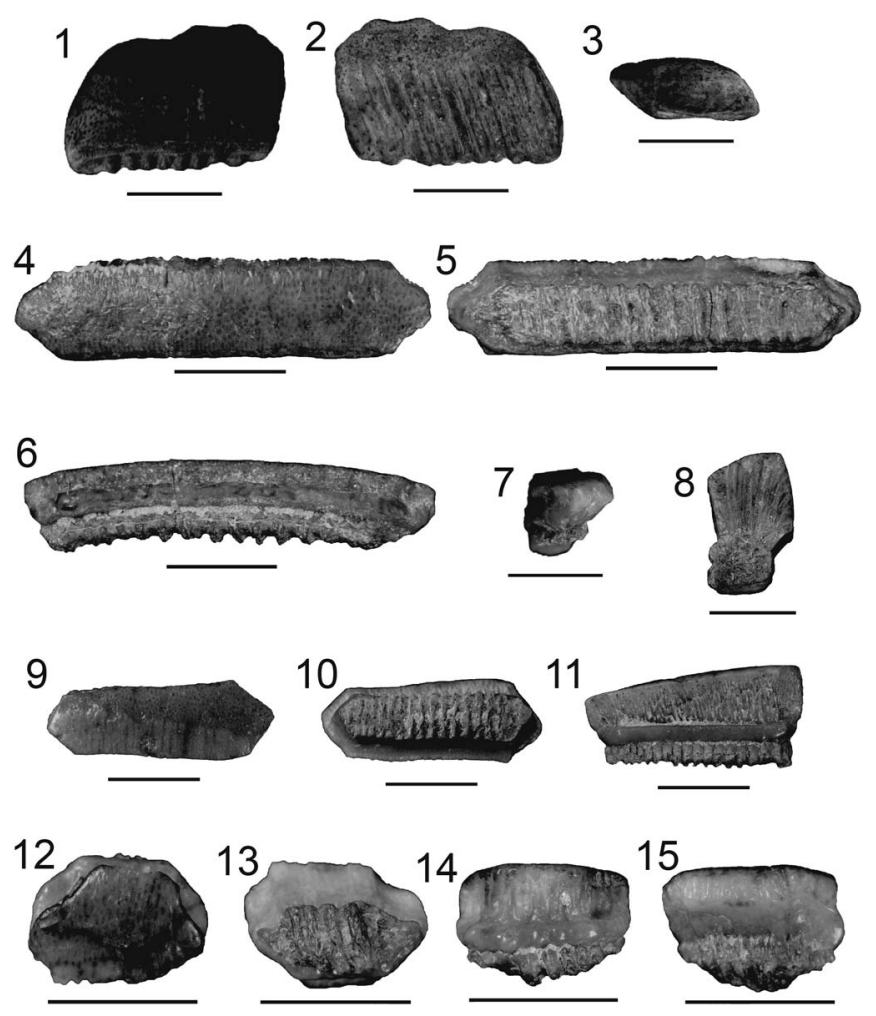

Figure 10. Batoid II: Aetobatus and Rhinoptera images from the Chucunaque Formation. (1-3) Aetobatus sp., UF 281226, distal tooth fragment in occlusal, basal, and lateral view, respectively; (4-15) Rhinoptera sp.: (4-7) UF 281307, symphyseal (i.e., medial) tooth in occlusal, basal, lingual, and lateral view, respectively; (8) UF 281309, cross-section in lateral view; (9-11) UF 281308, lateral (i.e., intermediate) tooth in occlusal, basal, and lingual view, respectively; (12-15) UF 281304, lateral (i.e., distal) tooth in occlusal, basal, lingual, and labial view, respectively (scale bars $=5 \mathrm{~mm}$ ). Photo credit: S. Moran.

UF 281308, UF 281311, UF 281313; indeterminate position: UF 281302-281303, UF 281305-06, and UF 281309-281311.

Remarks.-Rhinoptera can be distinguished from Aetobatus by its high crown and hexagonal outline with angular extremities. Rhinoptera is also often confused with Myliobatis; however, Rhinoptera differs in having a higher crown, a more angular occlusal surface, and a thicker lingual cingulum (Laurito and Valerio, 2008). Myliobatis was not observed in the Chucunaque Formation, but has been reported from the Gatun Formation, along with Rhinoptera cf. R. steindachneri (Pimiento et al., 2013a). The small, yet significant, relative abundance of Rhinoptera in the Gatun Formation ( 4\%) is comparable to that seen in the Chucunaque Formation (2.7\%; Fig. 12). The size range of Rhinoptera teeth from the Gatun Formation $(\mathrm{CH}=$ $3.0-5.0 \mathrm{~mm}, \mathrm{CW}=3.0-26.0 \mathrm{~mm}$, and $\mathrm{CL}=4.0-5.0 \mathrm{~mm})$ is fairly close to that observed in Bayano. The significantly larger range in $\mathrm{CW}$ can likely be explained by the occurrence of a large symphyseal tooth in the Gatun Formation. Rhinoptera steindachneri occurs in tropical waters in the eastern Pacific, usually between 0 and $30 \mathrm{~m}$ depth (Humann and Deloach, 1993).

Family Mobulidae Gill, 1893

Genus Mobula Rafinesque, 1810 
Type.-Mobula auriculata Rafinesque, 1810 (Cappetta, 2012).

Mobula thurstoni (Lloyd, 1908)

Figure 11.1-11.15

Holotype.-Originally described as Dicerobatis thurstoni by Lloyd (1908).

\section{Occurrence.-STRI 290109 and YPA105.}

Description.-In occlusal view, teeth have a roughly elliptical outline with a "blistered" ornamentation. The lingual edge is irregular and cuspidate, whereas the labial edge is convex or sinuous. The number of cusps on the lingual edge increases in more elongate specimens (Adnet et al., 2012) and the enamel extends well onto the root on the lingual face. The labial visor is rounded and may be incised with furrows. The root may have two or more lobes, depending on the position of the tooth and the age of the individual (Adnet et al., 2012); the root is narrow relative to the crown. The crown slopes inward basally, creating an angular contact with the divergent root lobes. In UF 281256 (Fig. 11.11-11.13), the root is divided into two lobes by a shallow medial groove (e.g., holaulacorhize stage); in labial view, the right lobe is larger, indicating a left lateral position. Teeth range from $\mathrm{CH}=0.47-0.63 \mathrm{~mm}, \mathrm{CW}=0.98-1.40 \mathrm{~mm}$, and $\mathrm{CL}=1.37-2.04 \mathrm{~mm}$.

Materials.-Sixteen isolated teeth; lateral: UF 281256, UF 281291-93, UF 281295, UF 281481; indeterminate position: UF 281283-85, UF 281288, UF 281294, and UF 281482.

Remarks._Adnet et al. (2012) noted reduced sexual dimorphism in Mobula thurstoni, with the only major difference being that males are more deeply scored by furrows on the labial face. Pimiento et al. (2013a) identified two female teeth as Mobula thurstoni from the Gatun Formation. The specimen of M. thurstoni imaged in Pimiento et al. (2013a) has four cusps on the lingual edge, irregular folding on the labial edge, and a relatively smooth occlusal surface $(\mathrm{CW}=0.6 \mathrm{~mm}$ and $\mathrm{CL}=1.1 \mathrm{~mm})$, which bears a strong resemblance to the female teeth of Mobula tarapacana described by Adnet et al. (2012). The additional cusps on the Gatun specimen can be explained by the fact that the number of cusps increases as teeth become more elongate (Notarbartolo Di Sciara, 1987; Adnet et al., 2012). Adnet et al. (2012) provisionally placed $M$. thurstoni into a group of Mobulids characterized by having comb-like teeth, along with M. munkiana and M. hypostoma, but distinguished M. thurstoni from the latter two by having an ornamented crown and shorter cusps. However, this distinction is tenuous (Adnet et al., 2012) and may not hold true in the fossil record. This species likely has a circumtropical distribution, but is known from scattered reports throughout the Pacific and Atlantic (Notarbartolo Di Sciara, 1987; Compagno, 1997). Extant individuals occur in oceanic and coastal waters, but most frequently are encountered in coastal environments from 0-100 m (Notarbartolo Di Sciara, 1988; McEachran and Notarbartolo Di Sciara, 1995; Clark et al., 2006a).

\section{Mobula cf. M. tarapacana (Philippi, 1892) Figure 11.16-11.25}

Holotype.-Originally described as Cephaloptera? tarapacana from Chile by Philippi (1893, p. 8, pl. 3, fig. 2).

\section{Occurrence.-STRI 290109 and UF YPA105.}

Description.-Sexual dimorphism is a marked character in Mobula tarapacana (Adnet et al., 2012). Male teeth are elongate in occlusal view with deeply scored furrows and a subhexagonal outline. The labial edge is convex and slightly irregular. The lingual edge is sharp and cuspidate. The crown apex is much broader than the base of the crown. The root is polaulocorhizid with numerous labiolingually compressed lobes (Fig. 11.1611.20). Female teeth have a relatively smooth occlusal surface with a subhexagonal outline. The crown is high relative to the root, with a slender profile. Adnet et al. (2012) observed crown heights two to three times greater than the root height in extant individuals. The labial edge is deeply grooved and the lingual edge is irreglularly cuspidate. The root is polaulocorhizid, root lobes are rounded and irregularly divided.

Materials.-Ten isolated teeth; male: UF 281270-71, UF 281276, UF 281485, UF 281497; female: UF 281289, UF 281483-84; indeterminate: UF 281487.

Remarks. - Mobula tarapacana has not previously been reported from the fossil record of Panama. Mobula cf. M. tarapacana specimens from the Chucunaque Formation have a significant dental sexual dimorphism, primarily reflected by the stronger ornamentation of male teeth. Adnet et al. (2012) also observed this feature in extant individuals, however the deep labiolingual furrows exhibited in the fossil specimens seem more irregular. It is possible that this morphotype represents an extinct species. Cappetta (1970) noted similarities with the extant species, Mobula tarapacana, in his original description of Mobula loupianensis and

Figure 11. Batoid III: Images of Mobula teeth from the Chucunaque Formation. (1-15) Mobula thurstoni (Lloyd, 1908): (1-5) UF 281291, lateral tooth in occlusal, lingual, labial, basal, and profile view, respectively; (6-10) UF 281292, anterolateral tooth in occlusal, lingual, labial, basal, and lateral view, respectively; (11-13) UF 281256, SEM image of a left lateral tooth in occlusal, lingual, and labial view, respectively; (14, 15) UF 281283, SEM image of a lateral tooth in occlusal and lateral view, respectively; (16-25) Mobula cf. M. tarapacana (Phillippi, 1893): (16-20) UF 281270, lateral male tooth in occlusal, lingual, labial, basal, and lateral view, respectively; (21-25) UF 281289, lateral female tooth in occlusal, lingual, labial, basal, and lateral view, respectively; (26-50) Mobula sp.: (26-31) Type I: (26, 27) UF 281279, SEM image of a lateral tooth in occlusal and lateral view, respectively; (28-30) UF 281280, SEM image of an anterior tooth in occlusal, lingual, and labial view, respectively; (31) UF 281287, SEM image of a indeterminate tooth position in occlusal view; (32-45) Type II: $(\mathbf{3 2}, \mathbf{3 3})$ UF 281243, SEM image of an anterior tooth in occlusal and lateral view, respectively; (34, 35) UF 281241, SEM image of an anterior tooth in occlusal and lateral view, respectively; (36-38) UF 281251, SEM image of an aneterior male tooth in occlusal, lingual, and lateral view, respectively; $(39,40)$ UF 281253, SEM image of a lateral male tooth in occlusal and lateral view, respectively; (41-45) UF 281490, lateral tooth in occlusal, lingual, labial, basal, and lateral view, respectively; (46-50) Type III: (46-48) UF 281255, SEM image of a female? lateral tooth in occlusal, lingual, and apico-labial view, respectively $(\mathbf{4 9}, \mathbf{5 0})$ UF 281299, SEM image of a female? tooth in occlusal and lingual view, respectively (scale bars $=1 \mathrm{~mm})$. 


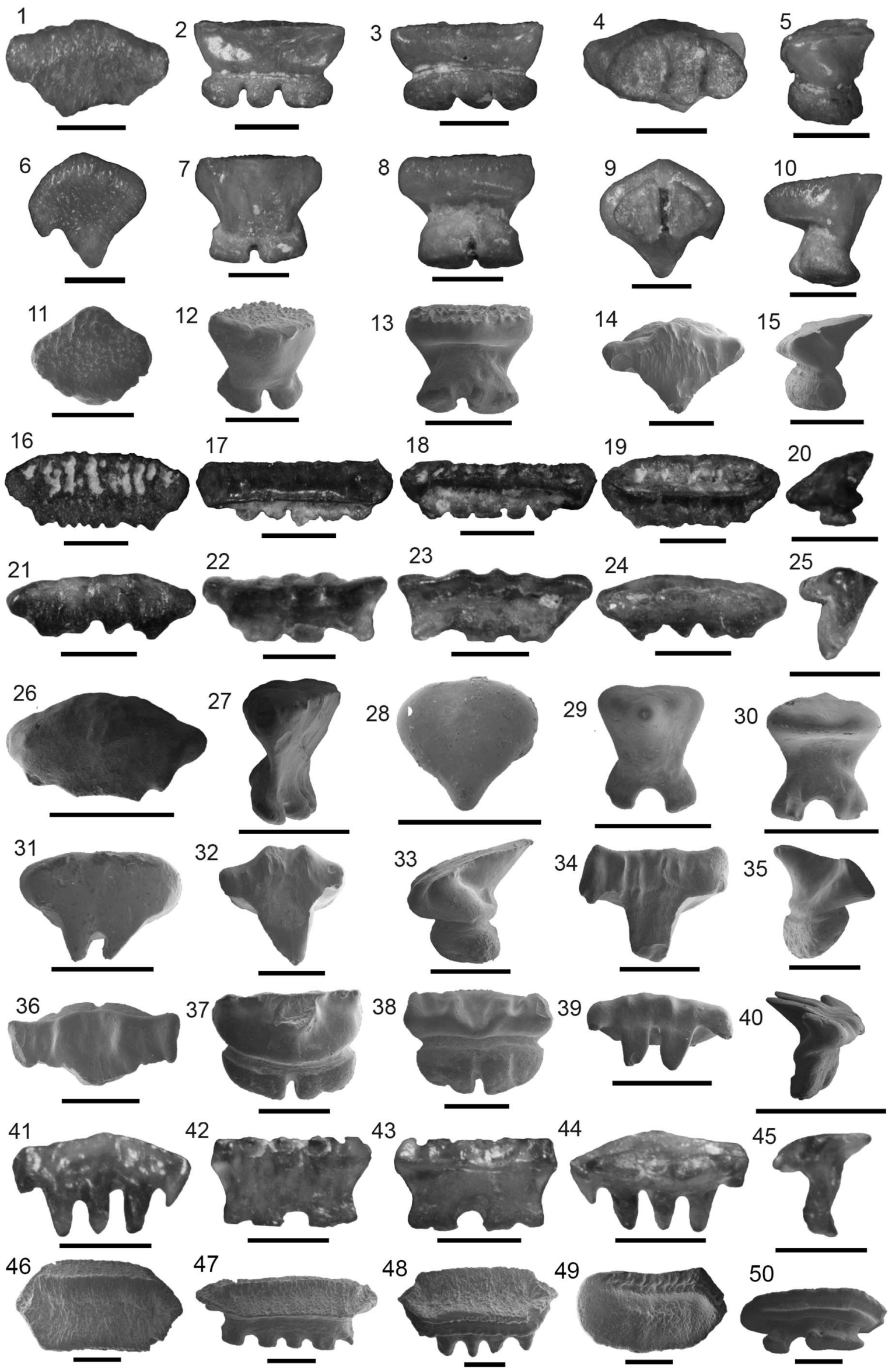


Mobula pectinata. Adnet et al. (2012) placed M. tarapacana in a distinct group within the mobulids characterized by having a cobblestone tooth plate. Extant individuals have a circumglobal distribution in temperate and tropical environments (Notarbartolo Di Sciara, 1987; Clark et al., 2006b). Mobula tarapacana is predominantly oceanic, but also occurs in coastal waters, inhabiting depths of 0-30 m (Feitoza et al., 2003).

Mobula spp.

Figure 11.26-11.50

Occurrence.-STRI 290109, STRI 290113, STRI 290116, and YPA105.

Description.-Numerous tooth forms with varying degrees of ornamentation were observed; however, they can be broadly placed into three morphotypes. Type I teeth lack ornamentation altogether (Fig. 11.26-11.31), and may be irregularly cuspidate (Fig. 11.26), bicuspidate (Fig. 11.31), or have a single cusp (Fig. 28). The crowns of Type I teeth are broad apically and slender basally, with enamel that extends well onto the root on the lingual face and forms a distinct ridge at the crown-root contact on the labial face. The root may be holaulochorizid or polyaulochorizid with slender, divergent root lobes. Many of these characters are similar to extant female Mobula tarapacana as well as the extinct species Mobula loupianensis, which is not unexpected given that Cappetta (1970) noted similarities between the two in his original description of M. loupianensis. UF 281287 has a $\mathrm{CH}=0.91 \mathrm{~mm}, \mathrm{CW}=1.06 \mathrm{~mm}$, and $\mathrm{CL}=$ $1.59 \mathrm{~mm}$ (Fig. 11.31).

Type II teeth have a prominent central cusp and may have two or more minor lateral cusplets on the distal and mesial edges (Fig. 11.32-11.45). In apical view, the occlusal surface is smooth, but bears deep troughs and complimentary ridges that extend onto the labial edge. The root is low and narrow relative to the crown and is divided into two or three lobes; in UF 281251 and UF 281490 (Fig. 11.36, 11.43) the two lobes are weakly incised, beginning to form two additional lobes. This multicuspidate form strongly resembles extant males of the species Mobula hypostoma, but also bears similarities with extant males of Mobula rochebrunei and the extinct species Mobula loupianensis. UF 281251 has a $\mathrm{CH}=0.71 \mathrm{~mm}$, $\mathrm{CW}=0.92 \mathrm{~mm}$, and a $\mathrm{CL}=2.09 \mathrm{~mm}$ (Fig. 11.36-11.38).

Type III teeth are elongate with a nearly hexagonal outline; the crown is shallow and inclined with a concave occlusal surface bearing a granular ornament (Fig. 11.46-11.50). There is a transverse crest that follows the contour of the labial edge; the labial edge is slightly convex; and the lingual edge is straight to slightly concave. The mesial and distal edges may be angular or subrounded, likely due to positional variability within the dental plate (Adnet et al., 2012). The root is high relative to the crown, and may be holaulocorhizid or polyaulacorhizid. In UF 281299, the crown is short and subhexagonal, bearing a transverse crest that follows the contour of the labial edge. The labial side of the crest is coarsely ornamented; the lingual side has a fine ornamentation that fades out distally (Fig. 11.49, 11.50; $\mathrm{CH}=0.17 \mathrm{~mm}, \mathrm{CW}=1.51 \mathrm{~mm}$, and $\mathrm{CL}=0.82 \mathrm{~mm}$ ). The largest specimen, UF 281255 (Fig. 11.46-11.48), has a $\mathrm{CW}=3.48 \mathrm{~mm}$ and $\mathrm{CL}=1.86 \mathrm{~mm}$.
Materials.-One hundred forty; Type I $(\mathrm{N}=8)$ : UF 281268 , UF 281278-81, UF 281287-88, UF 281496; Type II ( $\mathrm{N}=60)$ : UF 281239, UF 281241, UF 281243, UF 281246, UF 281248 49, UF 281251, UF 281253-54, UF 281257-58, UF 28126163, UF 281265-67, UF 281273, UF 281282, UF 281286, UF 281290, UF 281296, UF 281298-99, UF 281490-91; Туре III $(\mathrm{N}=70)$ : UF 281240, UF 281244-45, UF 281247, UF 281250, UF 281252, UF 281255, UF 281259-60, UF 281264, UF 281269, UF 281274-75, UF 281277, UF 281297, UF 281486, UF 281489, UF 281492-95, UF 281498; indeterminate fragments $(\mathrm{N}=2)$ : UF 281300-01.

Remarks.-Notarbartolo Di Sciara (1987) noted that heterodonty is one of the most salient mobulid characteristics and suggested that tooth morphology as a systematic tool may be problematic. Adnet et al. (2012) provided a comprehensive overview of the evolutionary history of mobulid rays with a particular focus on dental characters and the evolution of planktivory. The distinction between different species, and especially between different genders, is largely based on crown ornamentation. However, additional work must still be done to better understand the robustness of crown ornamentation as a phylogenetic tool, especially in consideration of other Miocene-aged extinct species such Mobula loupianensis, Mobula pectinata, Mobula fragilis, and Plinthicus. Cappetta (2012) attributed the reduction in tooth size and crown ornamentation in the genus Burnhamia to a change in diet, which may indicate a greater relationship between ornamentation and environment than with evolutionary history. The tooth morphology of Type III teeth definitely resembles that of Burnhamia, which is considered a stem mobulid by Cappetta (1987, 2012). Burnhamia is an extinct genus that has been reported from the late Paleocene through the Eocene, and was placed in the family Mobulidae due to its reduced tooth size relative to rhinopterids (Cappetta, 2012).

Given that sexual dimorphism is an extremely marked character in the genus Mobula (Notarbartolo Di Sciara, 1987; Adnet et al., 2012; Cappetta, 2012), it seems likely that Type III teeth are female counterparts to the male Type II morphotype. The more cuspidate crowns of males compared to females likely reflect different feeding mechanisms and possibly different prey items, which would aid in reducing competition between genders. Adnet et al. (2012) places Mobula hypostoma in a group of mobulids characterized by having comb-like teeth, which are similar to the Type II morphotype described herein. Male teeth are imbricated with their cusps oriented lingually (Radcliffe, 1916; Notarbartolo Di Sciara, 1987), which may aid in grasping small prey and directing it inward. Mobula hypostoma feed primarily on zooplankton, but will also eat small pelagic crustaceans and ray-finned fishes (McEachran and Carvalho, 2002). Mobula hypostoma has been identified from the Gatun Formation of Panama (Pimiento et al., 2013a) and the late Miocene-Pliocene of Costa Rica (Laurito, 1999); however, Laurito (1999) only identified male M. hypostoma teeth. Extant individuals occur in tropical to subtropical waters in the Western Atlantic, and often have a coastal preference, but may occur in oceanic waters as well (Notarbartolo Di Sciara, 1987; McEachran and Carvalho, 2002; Bizzarro et al., 2009). Mobulid rays are placed in the aquilopelagic ecomorphotype described 
by Compagno (1990) because of their birdlike locomotive behavior and coastal to oceanic habitat.

Order Myliobatiformes incertae sedis

Figure 8.12-8.14

\section{Occurrence.-YPA105.}

Description.-Fragmentary dorsoventrally compressed caudal spines. UF 281317 has four barbs that are directed toward the base of the spine. The barbs and dorsal surface are covered in an enameloid sheath. There is a nutrient pore beneath each of the barbs. The caudal spine fragment has a length of $4.50 \mathrm{~mm}$ and a width of $2.09 \mathrm{~mm}$ (Fig. 8.12, 8.13).

Materials.-Two isolated caudal spine fragments: UF 281317 and UF 281499.

Remarks.-It is difficult to identify complete caudal spines to the genus or species level, let alone a fragment of one. Pimiento et al. (2013a) described a single caudal spine from the Gatun Formation and attributed it to the genus Urobatis. CarrilloBriceño et al. (2015a) reported a single caudal spine in both the neritic Rio Indio facies and the bathyal Piña Sandstone facies of the Chagres Formation, but was unable to identify either beyond Batomorphii. Schwartz (2007) analyzed 34 extant species of rays in search of diagnostic characters for stingray caudal spines. Characteristics taken into account were total spine length, pre-base length, number of serrations, presence of serrations on the spine base, and presence and size of a dorsal groove. Schwartz (2007) found that no single character was sufficient for identifying a spine, however an aggregate of all of these characters could elucidate the identity. The fragment described herein lacks sufficient characters to identify it beyond the order Myliobatiformes.

\section{Superorder Batomorphii incertae sedis} Figure 8.15, 8.16

\section{Occurrence.-YPA105.}

Description.-A simple, slender dermal denticle with a reticulate dentine interior coated by an enameloid sheath. The basal plate is elongate and oval-shaped, forming a platform for a conical, posteriorly oriented apex. The dermal denticle has a basal length of $1.40 \mathrm{~mm}$, basal width of $0.47 \mathrm{~mm}$, and a height of $1.51 \mathrm{~mm}$.

Materials.—One isolated dermal denticle: UF 281401.

Remarks.-Dermal denticles, or placoid scales, have a composition analogous to teeth with a pulp cavity, dentine interior, and enameloid exterior (Kent, 1994); and it has been stated that teeth were evolutionarily derived from dermal denticles (Peyer, 1968). In sharks, dermal denticles tend to cover the entire body-aiding in hydrodynamics, acting as a predation deterrent, and reducing skin abrasion (Applegate, 1967; Reif, 1988; Kent, 1994). In stingrays, and some sharks, dermal denticles are often modified as a defensive measure (Kent, 1994). The dermal denticle described herein is likely of this sort; in which it has been modified as a defensive thorn, lacking the flattened, fluted morphology typical of dermal denticles that primarily function for enhanced hydrodynamics. A number of batoids possess caudal thorns that are specialized for a defensive purpose, including Dasyatis. Typically, caudal thorns of Dasyatis have a stellate basal plate (Nair and Soundararajan, 1976; Silas and Selvaraj, 1985); however the morphology of dermal denticles can vary based on position in the body, throughout ontogeny, between sexes, between individuals, and between different species (Roberts and Karnasuta, 1987). No other dermal denticles have been described from the fossil record of Panama, however this is likely due to a collection bias given their extremely small size and relatively delicate form.

\section{Discussion}

Taxonomic composition.-In total, 1422 dental remains revealed at least 31 different chondrichthyan taxa (Table 3), 23 of which belong to the subdivision Selachii (modern sharks) and 8 of which belong to the subdivision Batomorphii (skates, rays, and sawfish). There are five orders consisting of 12 families and 19 genera (Fig. 12). Seven non-dental remains were also described, including four vertebral centra, one dermal denticle, and two fragmentary caudal spines. At least 15 of the 31 taxa identified represent extant species (Table 3), confirming that the late Miocene chondrichthyans are long-lived species. Also, among the 31 taxa recognized, at least eight are new records for the fossil record of Panama (Table 3).

There is undoubtedly some degree of bias in the sample, whether it is due to collection, preservation, or identification. The best way to reduce the potential bias is with a large sample size, and the sample described herein $(\mathrm{N}=1422)$ is the largest reported from Panama to date. Furthermore, our sampling efforts, as exhibited in randomized species accumulation curves

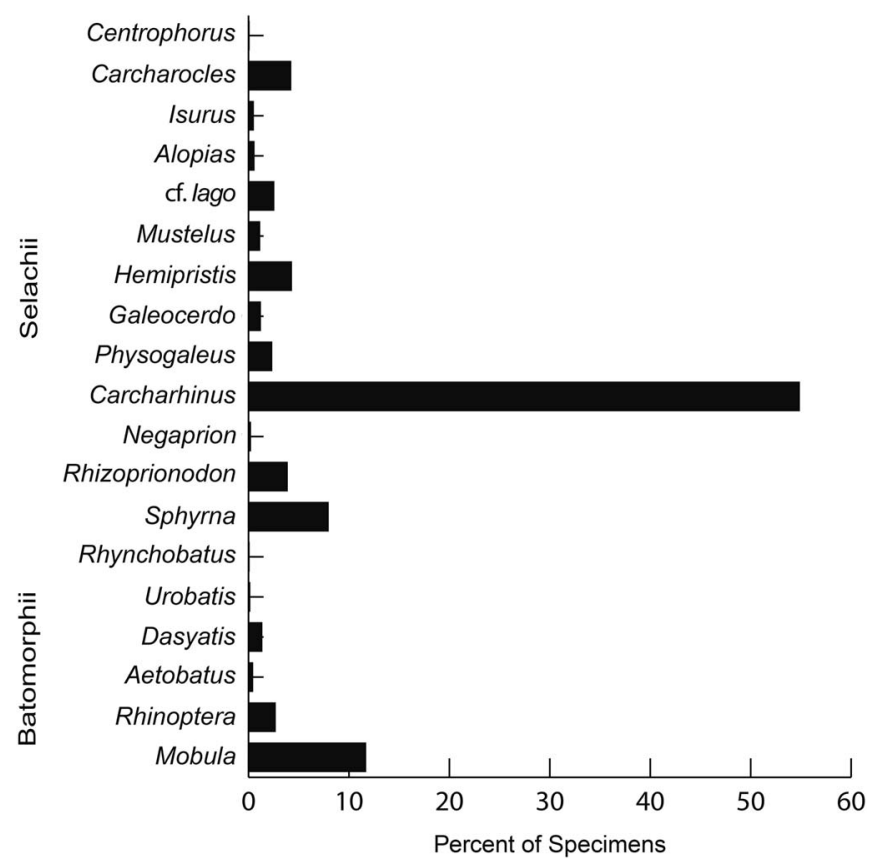

Figure 12. Relative abundance of chondrichthyan genera from the Chucunaque Formation. 
(Fig. 2) indicate that it is unlikely that more collecting (either surface prospecting or screewhasing) will result in many additional taxa. Hence, the sample utilized in this study comprises an accurate representation of the chondrichthyan biodiversity present in the Chucunaque Formation. There are three additional marine Miocene formations from Panama that have documented chondrichthyan remains: the early Miocene Culebra Formation with 12 taxa represented by 45 dental remains and 10 vertebral centra (Pimiento et al., 2013b); the middle-late Miocene Gatun Formation with 26 taxa represented by 800 dental remains (Pimiento et al., 2013a); and the late Miocene Chagres Formation with 30 taxa represented by 513 dental remains (Carrillo-Briceño et al., 2015a). The 1422 teeth collected and 31 taxa described herein from Lago Bayano comprise the most prolific and diverse chondrichthyan fauna known from Panama. Despite significant collection effort, all of these samples are subject to some degree of collection bias, and likely taphonomic bias. As such, proportions are reported to aid in the juxtaposition of these faunas, but should still be interpreted with caution.

Carcharhinus is by far the most abundant genus present in the Chucunaque Formation, representing over $50 \%$ of specimens identified (Fig. 12). Species of the genus Carcharhinus are the most abundant and diverse sharks in modern nearshore environments, with over 30 different species attributed to this genus (Compagno, 1984; Kent, 1994; Naylor and Marcus, 1994). Carcharhinus is also the most abundant genus represented in the Gatun Formation ( 40\%; Pimiento et al., 2013) and tied with Hemipristis as the most abundant genus in the Rio Indio Member of the Chagres Formation ( $32 \%$; Carrillo-Briceño et al., 2015a). In contrast, the deeper water Piña Sandstone facies of the Chagres Formation is dominated by species within the order Squaliformes, with only $\sim 11 \%$ of the chondrichthyan fauna being represented by the genus Carcharhinus (Carrillo-Briceño et al., 2015a).

The second most abundant genus in the Chucunaque Formation is Mobula ( 12\%; Fig. 12). Mobulids (Mobula and Manta rays) are the largest stingrays alive today, and typically have a pelagic, coastal habit in tropical and sub-tropical waters (Notarbartolo Di Sciara, 1987; Adnet et al., 2012). Mobula has been recognized from the Gatun Formation of Panama, but is much less abundant ( 1\%; Pimiento et al., 2013a). The paucity of Mobula in the paleontology literature can likely be attributed to preservation and collection bias. Mobula teeth are extremely small and have a very thin enameloid, and yet they are very common in the Chucunaque Formation. Increased screenwashing efforts in other tropical and sub-tropical Neogene localities may reveal more Mobula occurrences.

Functional diversity.-Six of the nine dentition types described by Kent (1994) were observed: cutting, crushing, clutching, vestigial, cutting-grasping, and grasping-cutting (Table 3; Fig. 13.1). The generalist, cutting-grasping type dentition was the most prevalent, being represented by $\sim 69 \%$ of the total sample. This dentition type is the most common today, and it allows for a wide variety of prey options, but it is most commonly found among sarcophagous (i.e., those eating fleshy prey such as bony fishes and marine mammals) and ichthyophagous (those eating fish) sharks (Kent, 1994). The second most common dentition type is the vestigial form $(\sim 12 \%)$, which is essentially a specialized tooth form for filter

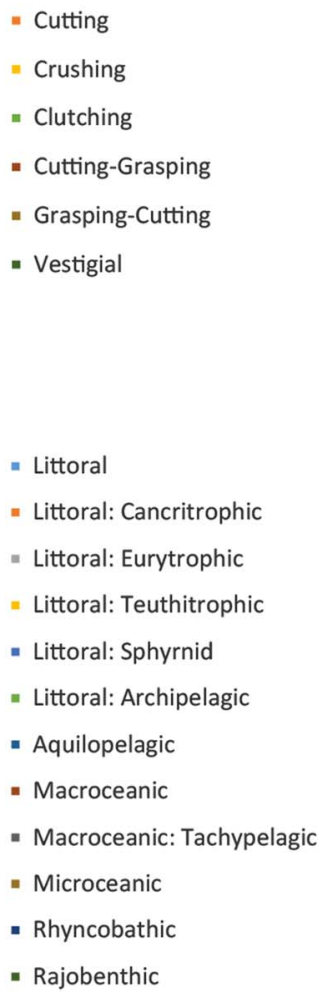

- Littoral

- Littoral: Cancritrophic

- Littoral: Eurytrophic

= Littoral: Teuthitrophic

- Littoral: Sphyrnid

- Littoral: Archipelagic

- Aquilopelagic

- Macroceanic

- Macroceanic: Tachypelagic

- Microceanic

- Rhyncobathic

- Rajobenthic
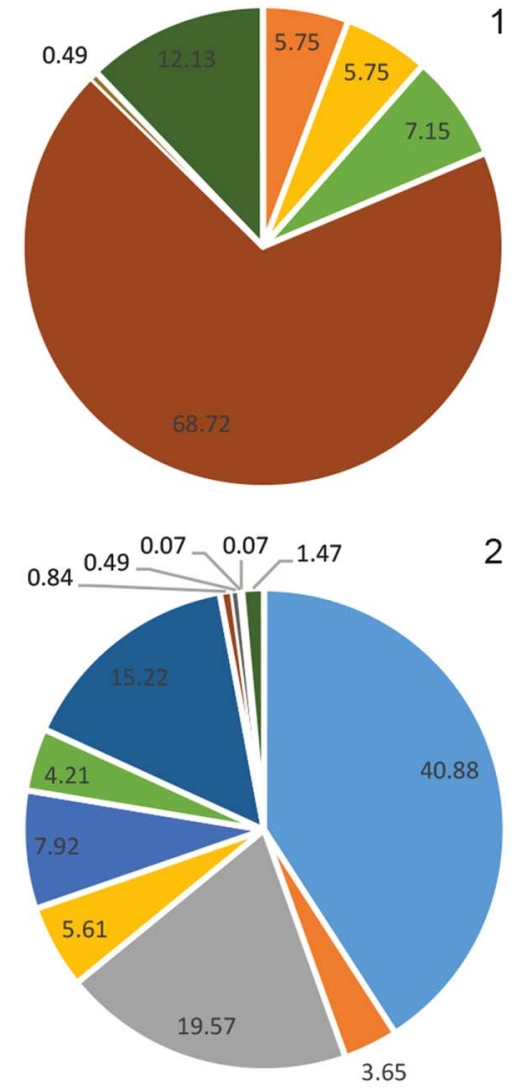

Figure 13. Two proxies for functional diversity. (1) Relative abundance of different dentition types as described by Kent (1994); (2) Relative abundance of different ecomorphotypes as described by Compagno (1990).

feeding, reflecting a planktivorous diet (Kent, 1994). This dentition type is represented by species within the genus Mobula. However, teeth of Mobula are not solely for filter feeding, but also possess some characteristics indicative of clutching and/or grinding. It has even been suggested that Mobula teeth may play a role during reproduction (Michael, 1993). Third is the clutching type $(\sim 7 \%)$, which is more typical of small to moderately sized sharks that primarily feed on small fishes and hard-bodied, benthic taxa (i.e., crustaceans, molluscs, and echinoids) by grabbing and gripping their prey with powerful shortened jaws (Kent, 1994). The fourth and fifth most common dentition types are the cutting type and the crushing type, both comprising 5.75\% of the specimens identified. The cutting type is adapted for sarcophagous taxa (Kent, 1994). The crushing type is a specialized form for feeding on armored benthic invertebrates (i.e., durophagous), such as molluscs and crustaceans, and is most typically found in bottom-dwelling taxa (Kent, 1994). Lastly, a very small portion, $0.5 \%$, had a grasping-cutting type dentition, which is represented by taxa in the genus Isurus. This dentition type relies more on capturing rather than dismembering the prey, which may be a more effective feeding strategy when operating in open water and feeding on more active prey items. Kent (1994) attributed this dentition type to ichthyophagous and teuthyophagous (i.e., those feeding on squid) sharks. It is also worth noting the absence of any taxa that have solely a grasping type dentition, such as Carcharias, which is a relatively common genus in Miocene deposits and in modern nearshore environments. In fact, among the 
four chondrichthyan-bearing Miocene deposits in Panama, only one tooth identified as Carcharias has been reported from the Chagres Formation (Carillo-Briceño et al., 2015a).

Furthermore, there were 12 ecomorphotypes represented by the chondricthyan fauna of Lago Bayano, most of which represent littoral taxa (Table 3; Fig. 13.2). The littoral ecomorphotype refers to relatively non-specialized taxa that inhabit continental shelves and feed on moderately sized prey comprised of bony fishes, crustaceans, and cephalopods, among other organisms (Compagno, 1990). Within the littoral habitus there are more specialized ecomorphotypes, including the cancritrophic (demersal sharks primarily feeding on bottom dwelling crustaceans), teuthitrophic (diet primarily consisting of cephalopods), sphyrnid (littoral to semilittoral with a specialized cephalofoil bowplane), eurytrophic (omnivores trending toward apex predator), and archipelagic (apex predators), that were also observed (Table 3; Fig. 13.2). Compagno (1990) grouped the eagle rays and cownose rays (Myliobatidae) with the devilrays (Mobulidae) into the aquilopelagic habitus because of their pectoral-driven locomotion, despite their very different feeding adaptations (Adnet et al., 2012). The aquilopelagic habitus represents $\sim 15 \%$ of the chondrichthyan fauna from the Chucunaque Formation. The oceanic habitus $(\sim 1.5 \%)$ is represented by three ecomorphotypes: macroceanic, tachypelagic, and microceanic. The remaining taxa are batoids placed in the rajobenthic $(\sim 1.5 \%)$ and rhynchobathic $(<0.1 \%)$ ecomorphotypes. Based on our functional diversity analyses, the ecosystems of Lago Bayano were dominated by generalist taxa that lived in nutrient-rich waters with abundant zooplankton.

Paleobathymetry.-The weighted paleobathymetry method was applied to the chondrichthyan fauna of the Chucunaque Formation, as well as the Gatun Formation and the Piña Sandstone facies of the Chagres Formation. For the Chucunaque Formation, 15 species of the 31 total taxa were included, which were represented by 525 specimens (37\% of the total number of material collected). For the Gatun Formation, 17 of the 26 taxa identified by Pimiento et al. (2013a) were included, which represented $\sim 32 \% \quad(\mathrm{~N}=257)$ of the specimens identified. For the Piña Sandstone facies of the Chagres Formation, 12 of the 28 taxa identified by Carrillo-Briceño et al. (2015a) were included, which represented $\sim 14 \%(\mathrm{~N}=70)$ of the specimens identified. This paleobathymetry method was not tested on the Rio Indio facies of the Chagres Formation because the chondrichthyan fauna therein is comprised of only four taxa identified to the species level that have modern analogs (Carrillo-Briceño et al., 2015a).

Our results (Table 4; Fig. 14) show that the Chucunaque Formation was most likely deposited in a neritic environment (mean depth of $110 \mathrm{~m}$ ). Previous studies (see Coates et al., 2004) proposed that this formation was deposited in the inner-neritic to upper-bathyal zone at different localities, based on benthic foraminiferal asssemblages. Variability in paleobathymetry throughout the Neogene succession and within individual sections was thought to correspond to spatial and temporal differences in sediment deposition and basin tectonics. Nevertheless, the river outcrops surveyed by Coates et al. (2004) were deposited in adjacent sedimentary basins (Chucunaque-Tuira and Sambu), whereas Lago Bayano resides on the western margin of the Bayano Basin, which likely experienced reduced subsidence and less accommodation space. Therefore there is little issue with the chondrichthyan fauna indicating a neritic environment for the Chucunaque Formation of Lago Bayano.

Similar to the Chucunaque Formation, the Gatun was deposited in a neritic environment (mean depth of $55 \mathrm{~m}$ ), whereas the Piña Sandstone facies was deposited within the upper bathyal zone (mean depth of $370 \mathrm{~m}$ ). The Chucunaque Formation and the Gatun Formation are both dominated by the order Carcharhiniformes ( $78 \%$ and $\sim 83 \%$, respectively), which is the most diverse and abundant group alive today in nearshore environments (Compagno, 1990; Kent, 1994). In contrast, the deeper water Piña Sandstone facies of the Chagres Formation is dominated by the order Squaliformes ( 70\%). The most abundant taxon identified from the Chagres Formation, Isistius $\mathrm{sp}$. $(\mathrm{N}=272)$, was not included in the paleobathymetric analysis because it was only identified to the generic level, and hence the depth range can only be inferred from the different living species within this genus or via other fossil occurrences. Carrillo-Briceño et al. (2015a) reported that Isistius ( $70 \%$ of the Piña Sandstone facies) occurs at depths of $0-3700 \mathrm{~m}$, usually between 0 and $1000 \mathrm{~m}$, based on the extant species

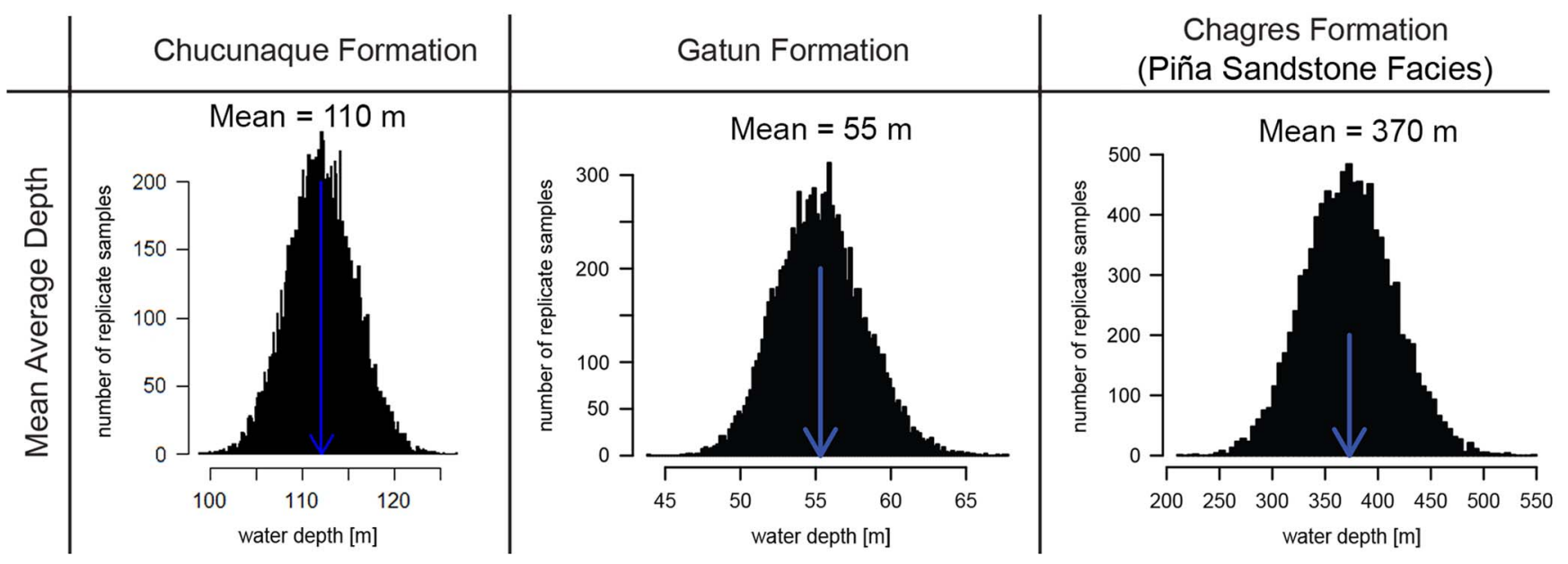

Figure 14. Paleobathymetric estimates for the Chucunaque Formation, Gatun Formation, and the Piña Sandstone facies of the Chagres Formation, showing the mean average depth. Depth ranges used in this analysis can be found in the Systematic Paleontology section as well as in Table 3. 
Isistius brasiliensis; however, they also noted that other living species of Isistius prefer shallow water and even make daily vertical migrations through the water column. If the preferred depth of I. brasiliensis were used as a proxy, its inclusion would have increased the mean average to $\sim 470 \mathrm{~m}$, but the estimate would still remain in the bathyal zone. The estimate for the Piña Sandstone facies is deeper than what was determined by Carrillo-Briceño et al. (2015a) based on chondrichthyan evidence alone. However, Collins et al. (1996) reported that the Chagres Formation was deposited in $200-500 \mathrm{~m}$ depth based on foraminiferal assemblages. Therefore, the depth inferred herein for the Piña Sandstone facies of the Chagres Formation would still fall within the range predicted by Collins et al. (1996) and is permissible given the presence of other deep-water taxa such as whales and billfishes (Uhen et al., 2010; CarrilloBriceño et al., 2015a; Velez-Juarbe et al., 2015).

Despite the fact that both the Chucunaque Formation and the Gatun Formation are interpreted as having been deposited in the neritic zone, the paleobathymetric prediction for the Chuncunaque Formation is nearly twice as deep as the Gatun Formation. This can be explained by the presence of pelagic taxa such as Isurus and Alopias in the Chucunaque Formation, which are absent in the Gatun Formation (Pimiento et al., 2013a). Furthermore, there are at least six taxa from the Chucunaque Formation (Isurus oxyrinchus, Alopias superciliosus, Alopias cf. A. vulpinus, Carcharhinus falciformis, Carcharhinus obscurus, and Sphyrna lewini), comprising $15 \%$ of the chondrichthyan fauna, that have depth ranges beyond the neritic zone (Table 3 ). The presence of these taxa may indicate the influence of deeper oceanic waters in the Bayano Basin (e.g., via upwelling systems) or may be explained by the migratory habits of these sharks. Many oceanic species migrate to shallow, coastal waters to give birth (Compagno, 1984, 1998; Bass et al., 1986; Mundy, 2005), which aids in reducing competition between juveniles and adults, and may help to prevent cannibalism (Compagno, 1990). Likewise, Carrillo-Briceño et al. (2014) recognized a chondrichthyan fauna, from the middle Miocene to early Pliocene of Ecuador, indicating a shallow- to deep-water assemblage and suggested that it may reflect a short platform environment bordered by deep water. The late Miocene Curré Formation (Laurito and Valerio, 2008) from Costa Rica bears a sparse chondrichthyan assemblage $(\mathrm{N}=89)$, relative to the Chucunaque Formation; however the two faunas are similar given that both are dominated by the order Carcharhiniformes, but also contain the genus Isurus. Laurito and Valerio (2008) inferred a neritic depth based on the chondrichthyan fauna and suggested that the depth is likely less than $35 \mathrm{~m}$ based on the occurrence of Pholididae traces. The presence of deep-water taxa along the Pacific Shelf of Costa Rica, Panama, and Ecuador during the late Miocene supports the idea of a proximal open ocean environment influencing the neritic Chucunaque Formation.

Our estimates presented here are a reflection of the taxonomic composition of the three localities studied and are in agreement with previous studies. However, there are obvious limitations to this method; namely, ignoring a large number of specimens either due to an inability to identify to the species level or because the species is extinct and lacks a modern analog to constrain its depth prefence. Further, there is undoubtedly some degree of preservational and/or collection bias, either due to uneven sampling efforts between screenwashed and surface collected material, or as an unavoidable result of thanatocoenosis (i.e., accumulation and deposition after death), as was suggested by Cappetta and Nolf (1991) in their paleobathymetric analysis. Even so, using the subsample of taxa that do have modern analogs and taking into account their relative abundance offers a quantitative, probabilistic approach that in theory will provide a more accurate paleodepth estimate. Likewise, Carrillo-Briceño et al. (2015c) employed a similar probabilistic approach using maximum likelihood estimation to predict the paleobathymetry of the Miocene Uitpa Formation in Colombia based on chondrichthyan occurrences.

Paleobiogeography.-The chondrichthyan fauna from the Gatun Formation has mixed biogeographic affinities, with evidence of taxa currently restricted to the Atlantic including Carcharhinus perezi, Rhynchobatus luebberti, Mobula hypostoma, and Taeniurops aff. T. grabata and Pacific-restricted taxa including Myliobatis cf. M. californica, Rhinoptera cf. R. steindachneri, and Mobula munkiana (Pimiento et al., 2013a). Of the 15 extant taxa observed from the Chucunaque Formation, all occur in both the Atlantic and the Pacific oceans today, with the possible exception of $C$. aff. macloti, given that extant C. macloti is restricted to the Pacific. Also, it is possible that the Type II Mobula teeth observed in the Chucunaque Formation actually belong to Mobula hypostoma, which would mean that there is an Atlantic-restricted species on the Pacific side of the evolving Panamanian isthmus. If even one of these species were accurately identified as representing a species that is currently restricted to the opposing side of the isthmus, it would support the hypothesis that there was a continued marine connection between 9 Mya and 10 Mya.

The Chucunaque Formation of Lago Bayano is roughly contemporaneous with the upper part of the Gatun Formation (Hendy, 2013; Pimiento et al., 2013a). The Gatun Formation of the Panama Canal Basin is considered to have had a Caribbean affinity based on benthic foraminiferal assemblages (Collins et al., 1996), whereas the Chucunaque Formation of the Bayano Basin has been interpreted as having a Pacific affinity (Coates et al., 2004). The two distinct foram assemblages have been utilized to interpret restriction of deep-water circulation by $\sim 8$ million years ago; however, this deep-water connection is thought to have returned $\sim 6$ million years ago based on Pacific foraminifera in the bathyal Chagres Formation (Collins et al., 1996). Despite the fact that there was, likely, ongoing shoaling of the Isthmus of Panama and restriction of deep-water circulation (Montes et al., 2012a, 2012b; Sepulchre et al., 2014), there must have still remained a marine connection between the Caribbean Sea and Pacific Ocean 10 million years ago to allow for exchange of marine vertebrates (Pimiento et al., 2013a). Sepulchre et al. (2014) incorporated neodymium isotopic data into a model in order to resolve the history of water masses connecting the Pacific to the Caribbean, and found that a seaway $50-200 \mathrm{~m}$ deep would likely have been present $\sim 10$ million years ago, which is consistent with the depth estimates for the Gatun and Chucunaque Formations, derived from the weighted paleobathymetric analysis (Table 4; Fig. 14).

The Lago Bayano fauna is therefore highly significant because it represents the first described Miocene chondrichthyan fauna from the Pacific shelf of Panama. The only other Miocene 
chondrichthyan faunas that have been described from the Pacific shelf of the evolving Central American isthmus are from the middle Miocene Punta Judas Formation (Laurito, 2004) and the late Miocene Curré Formation (Laurito and Valerio, 2008) from Costa Rica. The Curré Formation was tentatively assigned as being late Miocene because of the occurrence of chondrichthyan taxa typical of the Miocene and terrestrial mammal remains (Laurito and Valerio, 2005, 2008; Valerio and Laurito, 2008). The co-occurrence of terrestrial taxa as well as marine fauna in the Curré Formation is very similar to that of the late Miocene Alajuela Formation (MacFadden et al., 2015, 2017), providing evidence that at least some emergent land was present within the Central American isthmus. Coates and Obando (1996) reconstructed the CAS during the late Miocene as an archipelagic strait on the basis of tectonic evidence and nannofossil assemblages. Alternatively, it has been proposed that a continuous peninsula connected Panama to North America as early as 19 million years ago, based on comparable body sizes between contemporaneous land mammals found in North America and Panama (Kirby and MacFadden, 2005; Kirby et al., 2008). However, neither reconstruction excludes the notion of a marine connection between the Pacific Ocean to the Caribbean Sea throughout the Miocene.

After uplift of the Isthmus of Panama and complete closure of the CAS many taxa had populations in both the Pacific and Atlantic, with a few species becoming restricted to either side. With the information available we cannot yet ascertain if the reason these taxa became restricted is due to the closure of the CAS, but it is highly probable that the uplift of the Isthmus of Panama was a contributing factor. Given that chondrichthyan taxa are highly mobile, and that many are capable of transoceanic migrations, it is possible that they could continue to exchange between the Pacific and Atlantic via a meridional route after complete closure of the CAS. However, temperature restrictions would make this unlikely. A more reasonable explanation for the co-occurrence of Atlantic-restricted and Pacific-restricted taxa between 9 and 10 million years ago is that there was in fact a marine connection between the Caribbean Sea and the Pacific Ocean.

\section{Conclusion}

This overview of the chondrichthyan fauna from the late Miocene Chucunaque Formation reveals the most prolific and diverse assemblage from Panama, with at least 31 taxa, eight of which are new to the fossil record of Panama. Furthermore, the Lago Bayano fauna is the first described Miocene chondrichthyan assemblage from the Pacific shelf of the Panamanian isthmus, and ${ }^{87} \mathrm{Sr} /{ }^{86} \mathrm{Sr}$ isotopic ratios reported provide the first geochronology for the region. At least 15 of the taxa identified have affinities with extant species, which offers the opportunity to utilize the habitat preferences of the corresponding living species to make inferences regarding functional diversity, paleoenvironment, and paleobiogeography. The Bayano ecosystems are dominated by generalist sharks (with cutting-grasping type dentitions) and filter-feeding rays. A weighted paleobathymetric analysis provides evidence for a paleoenvironment in the neritic zone, with a mean average estimate of $110 \mathrm{~m}$. Finally, the geographic ranges of the fauna indicate mixed geographic affinity, which offers insight into a marine connection between the Caribbean Sea and the Pacific Ocean during a time of active shoaling in Central America.

\section{Acknowledgments}

This work was funded by U.S. National Science Foundation (NSF) grant 0966884 (OISE, EAR, DRL), 1358919 (EAR, OISE), and the Smithsonian Tropical Research Institution (STRI). We appreciate additional funding, in-kind support, and field assistance by C. Jaramillo, C. Montes, D. Ramirez, C. Suarez, L. Londoño, and V. Zapata (STRI), and R. Portell (FLMNH). We also acknowledge the generosity and guidance of the local Embrerá at Puente Bayano, in particular N. Ortega and S. Quiroz. In addition, R. Perez is acknowledged for donating the Toyota vehicles used for fieldwork, and the Dirección de Recursos Minerales are thanked for providing collecting permits. We thank R. Leder and S. Moran for help with macro photographs. We also appreciate the assistance from A. Heatherington with SEM images, D. Jones, G. Kamenov, and A. Waite for their help with the Sr-isotope analyses, the insightful comments of J. Carrillo-Briceño, as well as guidance on statistical methods (especially developing the $\mathrm{R}$ code for the bathymetric analyses) provided by M. Kowaleski. A Forschungskredit postdoctoral fellowship from the University of Zürich (FK-15-105) supported C.P. This is a contribution of the NSF Partnerships for International Research and Education Panama Canal Project and the University of Florida Contribution to Paleobiology number 762 .

\section{References}

Adnet, S., Cappetta, H., Guinot, G., and Notarbartolo Di Sciara, G., 2012, Evolutionary history of the devilrays (Chondrichthyes: Myliobatiformes) from fossil and morphological inference: Zoological Journal of the Linnean Society, v. 166, p. 132-159.

Agassiz, L. 1833-1843, Recherches sur les Poissons Fossils: Petitpierre, Neuchâtel, Suisse, v. 3, 390 p.

Aguilera, O., and Rodrigues De Aguilera, D., 2001, An exceptional coastal upwelling fish assemblage in the Caribbean Neogene: Journal of Paleontology, v. 75 , p. 732-742.

Antunes, M.T., 1970, Sur Lamna cattica ssp. tortuserrata; un cas de distribution antiéquatoriale: Revista da Faculdade de Ciencias: Universidade de Lisboa, v. 16 , p. $37-62$.

Antunes, M.T., 1978, Faunes ichthyologiques du Néogène supérieur d'Angola, leur âge, remarques sur le Pliocène marin en Afrique Australe: Ciências da Terra (University Lisboa), v. 4, p. 59-90.

Applegate, S.P., 1967, A survey of shark hard parts, in Gilbert, P.W., Mathewson, R.F., and Rall, D.P., eds., Sharks, Skates and Rays: Baltimore, Johns Hopkins Press, p. 37-67.

Bass, A.J., Heemstra, P.C., and Compagno, L.J.V., 1986, Carcharhinidae, in Smith, M.M., and Heemstra, P.C., eds., Smiths' Sea Fishes: Berlin, Springer-Verlag, p. 67-87.

Berg, L.S., 1940, Classification of fishes both recent and fossil: Travaux de l'Institut Zoologique de l'academie des Sciences de l'U.R.S.S., Leningrad, v. 5, p. 85-517. (in Russian)

Berg, L.S., 1958, System der rezenten und fossilen fischartigen und fische: Berlin, Deutsche Verlag Wissenschaften, 310 p.

Bertolini, F., 1933, Dentatura dei Selaci in rapporto con la nutrizione: Rendiconti Accademia Nazionale dei Lincei, v. 18, p. 234-237.

Bianchi, G., Carpenter, K.E., Roux, J.-P., Molloy, F.J., Boyer, D., and Boyer, H. J., 1999, Field Guide to the Living Marine Resources of Namibia. FAO Species Identification Field Guide for Fishery Purposes: Rome, Food and Agriculture Organization of the United Nations, $265 \mathrm{p}$.

Bizzarro, J., Smith, W., Baum, J., Domingo, A., and Menni, R., 2009, Mobula hypostoma. The IUCN Red List of Threatened Species. Version 2015.2. $<$ www.iucnredlist.org $>$ (accessed June 2015).

Blainville, H.M.D. de, 1816, Prodrome d'une nouvelle distribution systematique de regne animal: Bulletin de Sciences de la Société Philomatique de Paris, Pt. 8, p. 113-124. 
Blainville, H.M.D. de, 1818, Sur les ichthyolites ou les poissons fossils: Nouveau Dictionnaire d'Histoire Naturelle, v. 27, p. 310-391.

Bleeker, P., 1859, Enumeratio specierum piscium hucusque in Archipelago indico observatarum: Acta Societatis Scientiarum Indo-Neerlandae, v. 6 , p. $1-276$.

Bloch, M.E., and Schneider, J.G., 1801, Blochii systema ichthyologiae iconibus ex illustratum. Post Obitum Auctoris Opus Inchoatum Absolvit, Correxit, Interpolavit: Saxo, Jo. Gottlob Schneider, Berolini. Sumtibus Austoris Impressum et Bibliopolio Sanderiano Commissum, $584 \mathrm{p}$.

Bonaparte, C.L., 1838, Selachorum tabula analytica: Nuovi Annali delle Scienze Naturali, Bologna, v. 1, p. 195-214.

Bonfil, R., Amorim, A., Anderson, C., Arauz, R., Baum, J., Clarke, S.C., Graham, R.T., Gonzalez, M., Jolón, M., Kyne, P.M., Mancini, P., Márquez, F., Ruíz, C., and Smith, W., 2009, Carcharhinus falciformis: The IUCN Red Lis of Threatened Species 2009, e.T39370A10183906. http://dx.doi.org/10.2305/ IUCN.UK.20092.RLTS.T39370A10183906.en (accessed July 2016).

Bonnaterre, J.P., 1788, Ichthyologie. Tableau encyclopédique et méthodique des trois regnes de la nature. Paris, p. 215

Burgess, G.H. 2009, Carcharhinus brevipinna. The IUCN Red List of Threatened Species 2009: e.T39368A10182758. http://dx.doi.org/10.2305/IUCN.UK.20092. RLTS.T39368A10182758.en (accessed July 2016).

Burke, W. H., Denison, R. E., Hetherington, E. A., Koepnick, R. B., Nelson, H. F., and Otto, J. B., 1982, Variation of seawater ${ }^{87} \mathrm{Sr} /{ }^{86} \mathrm{Sr}$ throughout Phanerozoic time. Geology, v. 10, p. 516-519.

Cailliet, G.M., and Goldman, K.J., 2004, Age determination and validation in chondrichthyan fishes, in Carrier, J., Musick, A., and Hiethaus, M.R., eds., Biology of Sharks and Their Relatives: Boca Raton, Florida, CRC Press, p. 299-447.

Cailliet, G.M., Natanson, L.J., Welden, B.A., and Ebert, D.A., 1985, Preliminary studies on the age and growth of the white shark, Carcharodon carcharias, using vertebral bands: Memoirs of the Southern California Academy of Science, v. 9, p. 49-60.

Cailliet, G.M., Radke, R.L., and Welden, B.A., 1986, Elasmobranch age determination and verification: a review, in Uyeno, T., Arai, R., Taniuchi, T., and Masuura, K., eds., Indo-Pacific Fish Biology. Proceedings of the Second International Conference on Indo-Pacific Fishes: Tokyo, Ichthyological Society of Japan, p. 345-359.

Cailliet, G.M., Smith, W.D., Mollet, H.F., and Goldman, K.J., 2006, Age and growth studies of chondrichthyan fishes: the need for consistency in terminology, verification, validation, and growth function fitting: Environmental Biology of Fishes, v. 77, p. 211-228.

Cappetta, H., 1970, Les sélaciens du Miocène de la région de Montpellier: Paleovertebrata, Mémoire Extraordinaire, 139 p.

Cappetta, H., 1980, Modification du satut générique de queleques espèces de sélaciens crétacés et tertiares: Palaeovertebrata, v. 10, p. 29-42.

Cappetta, H., 1986, Types dentaires adaptaifs chez les selaciens actuels et post-paleozoiques: Paleovertebrata, v. 16, p. 57-76.

Cappetta, H., 1987, Chondrichthyes II: Mesozoic and Cenozoic Elasmobranchii. Handbook of Paleoichthyologie, 3B: Stuttgart, Gustav Fischer Verlag, $193 \mathrm{p}$

Cappetta, H., 2012, Chondrichthyes II (Mesozoic and Cenozoic Elasmobranchii: Teeth). Handbook of Paleoichthyology, 3E: Stuttgart, Gustav Fischer Verlag, $512 \mathrm{p}$.

Cappetta, H., and Nolf, D., 1991, Les sélaciens du Pliocène inférieur de Le-Puget-sur-Argens (Sud-Est de la France): Palaeontographica Abteilung A, p. $49-67$.

Caretto, P.G., 1972, Osservazoini tassonomiche su alcuni Galeoidei del Miocene Piemontese: Bolletino della Società Paleontologica Italiana, v. 11, p. $14-85$.

Carrillo-Briceño, J.D., Aguilera, O.A., and Rodriguez, F., 2014, Fossil Chondrichthyes from the central eastern Pacific Ocean and their paleoceanographic significance: Journal of South American Earth Sciences, v. 51, p. 76-90. DOI: 10.1016/j.jsames.2014.01.001.

Carrillo-Briceño, J.D., De Gracia, C., Pimiento, C., Aguilera, O.A., Kindlimann, R., Santamarina, P., and Jaramillo, C., 2015a, A new Late Miocene chondrichthyan assemblage from the Chagres Formation, Panama: Journal of South American Earth Sciences, v. 60, p. 56-70.

Carrillo-Briceño, J.D., Maxwell, E., Aguilera, O.A., Sánchez, R., and SánchezVillagra, M.R., 2015b, Sawfishes and other elasmobranch assemblages from the Mio-Pliocene of the South Caribbean (Urumaco sequence, Northwestern Venezuela): PLoS One, 10 (10), e0139230. DOI: 10.1371/ journal.pone.0139230.

Carrillo-Briceño, J.D., Argyriou, T., Zapata, V., Kindlimann, R., and Jaramillo, C., 2015c, A new early Miocene (Aquitanian) Elasmobranchii assemblage from the Guajira Peninsula, Colombia. Ameghiniana. v. 53, n. 2. <http://www.ameghiniana.org.ar/index.php/ameghiniana/article/view/77-99>.

Case, G.R., 1980, A selachian fauna from the Trent Formation, Lower Miocene (Aquitanian) of Eastern North Carolina: Palaeontographica Abt. A, v. 171, p. $75-103$.
Casper, B.M., Domingo, A., Gaibor, N., Heupel, M.R., Kotas, E., Lamónaca, A.F., Pérez Jimenez, J.C., Simpfendorfer, C., Smith, W.D., Stevens, J.D., Soldo, A., and Vooren, C.M., 2005, Sphyrna zygaena: The IUCN Red List of Threatened Species. Version 2015.2. <www.iucnredlist.org >. (accessed August 2015).

Cigala-Fulgosi, F., 1983, First Record of Alopias superciliosus (Lowe, 1839) in the Mediterranean, with Notes on Some Fossil Species of the Genus Alopias: Annali del Museo Civico di Storia Naturale di Genova, v. 84, p. 211-229.

Cigala-Fulgosi, F., 1988, Additions to the Eocene and Pliocene Fish Fauna of Italy: evidence of Alopias cf. denticulatus Cappetta, 1981 in the Bartonian-Priabonian of the Monte Piano Marl (Northern Apennines) and of A. superciliosus (Lowe, 1840) in the Pliocene of Tuscany (Chondrichthyes, Alopiidae): Tertiary Research, v. 10, p. 93-99.

Clark, T.B., Smith, W.D., and Bizzarro, J.J., 2006a, Mobula thurstoni: The IUCN Red List of Threatened Species. Version 2015.2. <www.iucnredlist. org >. (accessed July 2015).

Clark, T.B., Smith, W.D., and Bizzarro, J.J., 2006b, Mobula tarapacana: The IUCN Red List of Threatened Species. Version 2015.2. <www.iucnredlist. org >. (accessed July 2015).

Claro, R., 1994, Características generales de la ictiofauna, in Claro, R., ed., Ecología de los peces marinos de Cuba: Instituto de Oceanología Academia de Ciencias de Cuba and Centro de Investigaciones de Quintana Roo, Mexico, p. 55-70.

Coates, A.G., and Obando, J.A., 1996, The geologic evolution of the Central American Isthmus, in Jackson, J.B.C., Budd, A.F., and Coates, A.G., eds. Evolution and Environment in Tropical America: Chicago: University of Chicago Press, p. 21-56.

Coates, A.G., Collins, L.S., Aubry, M.P., and Berggren, W.A., 2004, The geology of the Darien, Panama, and the late Miocene-Pliocene collision of the Panama arc with northwestern South America: Geological Society of America Bulletin, v. 116, p. 1327-1344

Collins, L.S., Coates, A.G., Berggren, W.A., Aubry, M.P., and Zhang, J.J., 1996, The late Miocene Panama isthmian strait: Geology, v. 24, p. $687-690$.

Compagno, L.J.V., 1973, Interrelationships of living elasmobranchs: Zoological Journal of the Linnean Society, v. 53, p. 15-61.

Compagno, L.J.V., 1984, FAO Species Catalogue. Vol. 4. Sharks of the world An annotated and illustrated catalogue of shark species known to date: Rome, Food and Agriculture Organization of the United Nations, $655 \mathrm{p}$

Compagno, L.J.V., 1988, Sharks of the Order Carcharhiniformes: Princeton, NJ, Princeton University Press, $486 \mathrm{p}$.

Compagno, L.J.V., 1990, Alternative life-history styles of cartilaginous fishes in time and space: Environmental Biology of Fishes, v. 10, p. $33-75$

Compagno, L.J.V., 1997, Myliobatidae. Eagle rays, in Carpenter, K.E., and Niem, V.H., eds., FAO Species Identification Guide for Fishery Purposes. The Living Marine Resources of the Western Central Pacific. Vol. 3. Batoid fishes, chimaeras and bony fishes. Part 1 (Elopidae to Linophrynidae): Rome, Food and Agriculture Organization of the United Nations, p. 1511-1519.

Compagno, L.J.V., 1998, Lamnidae. Mackerel sharks, makos, white sharks, porbeagles, in Carpenter, K.E., and Niem, V.H., eds., FAO Identification Guide for Fishery Purposes. The Living Marine Resources of the Western Central Pacific: Rome, Food and Agriculture Organization of the United Nations, p. 1274-1278.

Compagno, L.J.V., 2001, Sharks of the World. An Annotated and Illustrated Catalogue of Shark Species Known to Date. Vol. 2. Bullhead, mackerel and carpet sharks (Heterodontformes, Lamniformes and Orectolobiformes) FAO Species Catalogue for Fishery Purposes: Rome, Food and Agriculture Organization of the United Nations, $269 \mathrm{p}$

Compagno, L.J.V., and Marshall, A.D., 2006, Rhynchobatus luebberti, in IUCN 2011, IUCN Red List of Threatened Species. Version 2011.2. <www. iucnredlist.org $>$.

Compagno, L.J.V., and Niem, V.H., 1998, Squalidae. Dogfish sharks, in Carpenter, K.E., and Niem, V.H., eds., FAO Identification Guide for Fishery Purposes. The Living Marine Resources of the Western Central Pacific: Rome, Food and Agriculture Organization of the United Nations, p. $1213-1232$.

Compagno, L.J.V. and Springer, S., 1971, Iago, a new genus of carcharhinid sharks, with a redescription of I. omanensis: Fishery Bulletin, v. 69 , p. $615-626$

Compagno, L.J.V., Ebert, D.A., and Smale, M.J., 1989, Guide to the Sharks and Rays of Southern Africa: London, New Holland (Publ.) Ltd., 158 p.

Compagno, L.J.V., Dando, M., and Fowler, S., 2005, Sharks of the World: Princeton, NJ, Princeton University Press, $368 \mathrm{p}$.

Cox, G., and Francis, M., 1997, Sharks and Rays of New Zealand: Canterbury, NZ, Canterbury University Press, University of Canterbury, $68 \mathrm{p}$.

Cuvier, G.L.C.F.D., 1829, Le regne animal, distribue dapres son organisation, pour servir de base a l'histoire naturelle des animaux et d'introduction a l'anatomie comparee. Edition 2: Paris, Deterville, 406 p. 
De Muizon, C., and De Vries, T.J., 1985, Geology and paleontology of late Cenozoic marine deposits in the Sacaco area (Peru): Geologische Rundschau, v. 74, p. 547-563.

Donovan, S.K., and Gunter, G.C., 2001, Fossil sharks from Jamaica: Bulletin of the Mizunami Fossil Museum, v. 28, p. 211-215.

Duque-Caro, H., 1990, Neogene stratigraphy, palaeoceanography and palaeobiogeography in northwest South America and the evolution of the Panama Seaway: Palaeogeography, Palaeoclimatology, Palaeoecology, v. 77, p. 203-234.

Eschmeyer, W.N., 1998, Catalog of Fishes: San Francisco, California Academy of Sciences. v. 1-3, p. 1-2905. (also CD-ROM with Access database).

Euphrasen, B.A., 1790, Raja (Narinari): Kongliga Vetenskaps Akademiens nya Handlingar, Stockholm, v. 11, p. 217-219.

Feitoza, B.M., Rocha, L.A., Luiz-Júnior, O.J., Floeter, S.R., and Gasparini, J.L., 2003, Reef fishes of St. Paul's Rocks: new records and notes on biology and zoogeography: aqua International Journal of Icthyology, v. 7, p. 61-82

Frazzetta, T.H., 1988, The mechanics of cutting and the form of shark teeth (Chondrichthyes, Elasmobranchii): Zoomorphology, v. 108, p. 93-107.

Garcia, S., 1994, World review of highly migratory species and straddling stocks: FAO Fisheries Technical Paper 337, Rome, Food and Agriculture Organization of the United Nations. $70 \mathrm{p}$.

Garman, S., 1913, The Plagiostomia (Sharks, Skates and Rays): Memoirs of the Museum of Comparative Zoology at Harvard College, $528 \mathrm{p}$.

Garrick, J.A.F., 1985, Additions to a Revision of the Shark Genus Carcharhinus: Synonymy of Aprionodon and Hypoprion, and Description of a New Species of Carcharhinus (Carcharhinidae): National Oceanic and Atmospheric Administration, National Marine Fisheries Service Technical Report, v. 34, p. $1-26$.

Garrick, J.A.F., Backus, R.H., and Gibbs, R.H., Jr., 1964, Carcharhinus floridanus, the silky shark, a synonym of C. falciformis: Copeia, v. 1964, p. $369-375$.

Geoffroy Saint-Hilaire, E., 1817, Poissons du Nil, de la Mer Rouge et de la Méditerranée, in Description de l'Egypte ou recueil des observations et des recherches qui ont été faites en Égypte pendant l'expedition de l'Armée fracais, publié par les orders de sa Majesté-L'Empereur Napoléon le Grand (Imprimerie Impériale): Paris, Histoire Naturelle, v. 1, pl. 18-27.

Gibbes, R.W., 1848-1849, Monograph of the fossil Squalidae of the United States: Journal of the Academy of Natural Sciences of Philadelphia, ser. v. 2, pt. 1, p. 139-206.

Gilbert, C.R., 1967, A revision of the Hammerhead Sharks (Family Sphyrnidae): Proceedings of the United States National Museum, v. 119, n. 3539, p. $1-82$.

Gill, T., 1872, Arrangement of the families of fishes, or Classes Pisces, Marsupiobranchii, and Leptocardii: Smithsonian Miscellaneous Collections, v. 247, p. 1-49.

Gill, T., 1893, Families and subfamilies of fishes: Memoirs of the National Academy of Sciences, v. 6, p. 125-138.

Gillette, D.D., 1984, A marine chondrichthyan fauna from the Miocene of Panama, and the Tertiary Caribbean faunal province: Journal of Vertebrate Paleontology, v. 4, p. 172-186.

Glikman, L.S., 1964, Sharks of the Paleogene and their stratigraphic significance: Moscow, Nauka Press, 229 p. (in Russian).

Goodrich, E.S., 1909, Vertebrata Craniata: (First Fascicle: Cyclostomes and Fishes): London, Adam and Charles Black, $518 \mathrm{p}$.

Gottfried, M.D., 1993, An associated tiger shark dentition from the Miocene of Maryland: The Mosasaur, v. 5, p. 59-61.

Gottfried, M.D., Compagno, L.J.V., and Bowman, S.C., 1996, Size and skeletal anatomy of the giant megatooth shark Carcharodon megalodon, in Klimley, A., and Ainley, D., eds., Great White Sharks: The Biology of Carcharodon carcharias: San Diego, CA, Academic Press, p. 55-89.

Gray, J. E., 1851, List of the specimens of fish in the collection of the British Museum. Part I. Chondropterygii: London, British Museum (Natural History), $160 \mathrm{p}$.

Griffith, E. and Smith, C.H., 1834, The class Pisces, arranged by the Baron Cuvier, with supplementary additions, by Edward Griffith, F.R.S. and Lieut.-Col. Charles Hamilton Smith, F.R., L.S.S., in Baron Cuvier, ed., The Animal Kingdom Arranged in Conformity with its Organization, with Additional Descriptions of all the Species Hitherto Named, and of Many Not Before Noticed, By Edward Griffith, and Others: London, L.S.S. \& Co., 680 p.

Grogan, E.D., Lund, R., and Greenfest-Allen, E., 2012, The origin and relationships of early chondrichthyans, in Carrier, J.C., Musick, J.A., and Heithaus, M.R., eds., Biology of Sharks and Their Relatives, $2^{\text {nd }}$ ed. New York, CRC Press, p. 3-29.

Gudger, E.W., 1937, Abnormal dentition in sharks, Selachii: Bulletin of the American Museum of Natural History, v. 73, p. 249-280.

Heist, E.J., Musick, J.A., and Graves, J.E., 1996, Genetic population structure of the shortfin mako (Isurus oxyrinchus) inferred from restriction fragment length polymorphism analysis of mitochondrial DNA: Canadian Journal of Fisheries and Aquatic Sciences, v. 53, p. 583-588.
Hendy, A.J.W., 2013, Spatial and stratigraphic variation of marine paleoenvironments in the upper Miocene Gatun Formation, Isthmus of Panama: Palaios, v. 28, p. 210-227.

Herman, J., 1982, Additions to the Eocene fish fauna of Belgium. 5. The discovery of Mustelus teeth in Ypresian, Paniselian and Wemmelian strata: Tertiary Research, v. 3, p. 189-193.

Herman, J., Hovestadt-Euler, M., and Hovestadt, D.C., 1988, Part A: Selachii. No. 2a: Order: Carcharhiniformes - Family: Triakidae: Bulletin de L'Institut Royal Sciences Naturelles de Belgique, v. 58, p. 99-126.

Hodell, D.A., and Woodruff, F., 1994, Variations in the strontium isotopic ratio of seawater during the Miocene: stratigraphic and geochemical implications: Paleoceanography, v. 9, 405-426.

Hoey, J.J., 1983, Analysis of longline fishing effort for apex predators (swordfish, shark, and tuna) in the western North Atlantic and Gulf of Mexico [Ph.D. Dissertation]: Kingston, University of Rhode Island, $288 \mathrm{p}$.

Holts, D.B., and Bedford, D.W., 1993, Horizontal and vertical movements of the shortfin mako shark, Isurus oxyrinchus, in the Southern California Bight: Marine and Freshwater Research, v. 44, p. 901-909.

Hooper, D.U., Solan, M., Symstad, A., Diaz, S., Gessner, M.O., Buchmann, N., Degrange, V., Grime, P., Hulot, F., Mermillod-Blondin, F., Roy, J., Spehn, E., and Van Peer, L., 2002, Species diversity, functional diversity and ecosystem functioning, in Loreau, M., Naeem, S., and Inchausti, P., eds., Biodiversity and Ecosystem Functioning: Syntheses and Perspectives, v. 17: Oxford, Oxford University Press, p. 195-208.

Howarth, R.J., and McArthur, J.M., 1997, Statistics for strontium isotope stratigraphy: a robust LOWESS fit to the marine Sr-isotope curve for 0 to $206 \mathrm{Ma}$, with look-up table for derivation of numeric age: The Journal of Geology, v. 105, p. 441-456.

Hulbert, R.C. Jr., Petkewich, R.M., Bishop, G.A., Bukry, D., and Aleshire, D.P., 1998, A new middle Eocene protocetid whale (Mammalia: Cetacea: Archaeoceti) and associated biota from Georgia: Journal of Paleontology, v. 72, p. 907-927.

Humann, P., and Deloach, N., 1993, Reef fish identification. Galápagos: Jacksonville, FL, New World Publications, Inc., 267 p.

Huxley, T.H., 1880, On the application of the laws of evolution to the arrangement of the Vertebrata, and more particularly of the Mammalia: Proceedings of the Zoological Society of London, v. 43, p. 649-662.

Iturralde-Vinent, M., Hubbell, G., and Rojas, R., 1996, Catalogue of Cuban fossil Elasmobranchii (Paleocene to Pliocene) and paleogeographic implications of their lower to middle Miocene occurrence: Journal of Geological Society of Jamaica, v. 31, p. 7-21.

Jordan, D.S., 1888, A Manual of Vertebrate Animals of the Northern United States, Including the District North and East of the Ozark Mountains, South of the Laurentian Hills, North of Virginia, and East of the Missouri River, Inclusive of Marine Species (fifth edition): Chicago, A.C. McClurg, $375 \mathrm{p}$.

Jordan, D.S., and Evermann, B.W., 1896, The fishes of North and Middle America: Bulletin of the United States National Museum, v. 47, p. 1-1240.

Jordan, D.S., and Hannibal, H., 1923, Fossil sharks and rays of the Pacific Slope of North America: Bulletin of the Southern California Academy of Sciences, v. 22, p. 27-63.

Kent, B.W., 1994, Fossil Sharks of the Chesapeake Bay Region: Columbia, Maryland, Egan Rees and Boyer, Inc., 146 p.

Kiraly, S.J., Moore, J.A., and Jasinski, P.H., 2003, Deepwater and other sharks of the U.S. Atlantic Ocean Exclusive Economic Zone: Marine Fisheries Review. v. 65, n. 4, p. 1-64.

Kirby, M.X., and MacFadden, B.J., 2005, Was southern Central America an archipelago or a peninsula in the middle Miocene? A test using landmammal body size: Palaeogeography, Palaeoclimatology, Palaeoecology, v. 228, p. $193-202$.

Kirby, M.X., Jones, D.S., and Ávila, S.P., 2007, Neogene shallow-marine paleoenvironments and preliminary strontium isotope chronostratigraphy of Santa Maria Island, Azores, in Ávila, S.P., and De Frias Martin, A.M., eds., Proceedings of the 1st "Atlantic Islands Neogene" International Congress, Ponta Delgada, 12-14 June 2006: Açoreana, Suplemento, 5, p. 112-115.

Kirby, M.X., Jones, D.S., and MacFadden, B.J., 2008, Lower Miocene stratigraphy along the Panama Canal and its bearing on the Central American Peninsula: PLoS One, 3(7), e2791.

Klausewitz, W., 1960, Die Typen und Typoide des Naturmuseums Senckenberg, 23: Pisces, Chondrichthyes, Elasmobranchii: Senckenbergiana Biologica, v. 41, p. $289-296$

Klunzinger, C.B., 1880, Die von Müller'sche Sammlung australischer Fische in Stuttgart: Sitzungsberichte der Kaiserlichten Akademie der Wissenschaften. Mathematisch-Naturwissenschaftliche Klasse, v. 80, p. 325-430.

Koepnick, R.B., Burke, W.H., Denison, R.E., Heatherington, E.A., Nelson, H. F., Otto, J.B., and Waite, L.E., 1985, Construction of the seawater ${ }^{87} \mathrm{Sr} /{ }^{86} \mathrm{Sr}$ curve for the Cenozoic and Cretaceous: supporting data: Chemical Geology (Isotope Geoscience Section), v. 58, p. 55-81. 
Lambert, O., Bianucci, G., Post, K., Muizon, C., Salas-Gismondi, R., Urbina, M., and Reumer, J., 2010, The giant bite of a new raptorial sperm whale from the Miocene epoch of Peru: Nature, v. 466, p. 105-108.

Last, P.R., and Stevens, J.D., 1994, Sharks and Rays of Australia: Clayton, VIC, Australia, CSIRO Publishing, $513 \mathrm{p}$.

Laurito, C.A., 1999, Los selaceos fosiles de la localidad de Alto Guayacan (y otros ictiolitos asociados), Mioceno Superior-Plioceno Inferior de la Formación Uscari, Provincia de Limon, Costa Rica: San Jose, Editora San Jose, 168 p.

Laurito, C.A., 2004, Ictiofauna de la Formación Punta Judas, Mioceno Medio, Provincia de Puntarenas, Costa Rica: Brenesia, v. 62, p. 57-73.

Laurito, C.A., and Valerio, A.L., 2005, First record of Rhynchotherium blicki (Frick, 1933) for the Late Cenozoic of Costa Rica: Revista Geologica de America Central, v. 33, p. 75-82.

Laurito, C.A., and Valerio, A.L., 2008, Ictiofauna de la localidad de San Gerardo de Limoncito, Formación Curré, Mioceno Superior, cantón de Coto Brus, provincia de Puntarenas, Costa Rica: Revista Geológica de América Central, v. 39 , p. $65-85$.

Leder, R.M., 2013, Eocene Carcharinidae and Triakidae (Elasmobranchii) of Crimea and Kazakhstan: Leipziger Geowissenschaften, v. 20, p. 1-57.

Leriche, M., 1927, Les poissones de la Molasse Suisse: Memoires de la Societe Paléontologique Suisse, v. 46-47, p. 1-120.

Lesueur, C.A., 1818, Description of several new species of North American fishes: Journal of the Philadelphia Academy of Natural Sciences, v. 1, p. $222-235$.

Linck, H.F., 1790, Versuch einer Eintheilung der Fische nach den Zahnen: Magazin für das Neueste aus der Physik und Naturgeschichte, v. 6, n. 3, p. 28-38.

Linnaeus, C., 1758, Systema Naturae per Regna Tria Naturae: Secundum Classes, Ordines, Genera, Species, cum Characteribus, Differentiis, Synonymis, Locis, $10^{\text {th }}$ ed.: Stockholm, Laurentius Salvius, 824 p.

Lloyd, R.E., 1908, On two new species of eagle-rays (Myliobatidae), with notes on the skull of the genus Ceratoptera: Records of the Indian Museum, v. 2 , p. $175-180$.

Long, D.J., 1993, Late Miocene and early Pliocene fish assemblages from the north central coast of Chile: Tertiary Research, v. 14, p. 117-126.

Longbottom, A.E., 1979, Miocene sharks' teeth from Ecuador: Bulletin of the British Museum (Natural History), London, (Geology), v. 32, p. 57-70.

Love, M.S., Mecklenburg, C.W., Mecklenburg, T.A., and Thorsteinson, L.K., 2005, Resource Inventory of Marine and Estuarine Fishes of the West Coast and Alaska: A Checklist of North Pacific and Arctic Ocean Species from Baja California to the Alaska-Yukon Border: U.S. Department of the Interior, U.S. Geological Survey, Biological Resources Division, Seattle, Washington, 98104, OCS Study MMS 2005-030 and USGS/NBII 2005-001.

Lowe, R.T., 1839-1841, A paper from the Rev. R.T. Lowe, M.A., describing certain new species of Madeiran fishes, and containing additional information relating to those already described: Proceedings of the Zoological Society of London, v. 8, p. 36-39.

Lucifora, L.O., García, V.B., and Worm, B., 2011, Global diversity hotspots and conservation priorities for sharks: PLoS One, 6(5), e19356.

MacFadden, B.J., Morgan, G.S., Jones, D.S., and Rincon, A.F., 2015, Gomphothere proboscidean (Gomphotherium) from the late Neogene of Panama: Journal of Paleontology, v. 89, p. 360-365.

MacFadden, B.J., Jones, D.S., Jud, N.A., Moreno, J., Morgan, G.S., Portell, R. W., Perez, V.J., Moran, S.M., and Wood, A.R., 2017, Integrated chronology, flora and faunas, and paleoecology of the Alajuela Formation, late Miocene of Panana: PLoS One, v. 12(1), p. e0170300.

MacPhee, R.D.E., Iturralde-Vinent, M.A., and Gaffney, E.S., 2003, Domo de Zaza, an early Miocene vertebrate locality in south-central Cuba, with notes on the tectonic evolution of Puerto Rico and the Mona Passage: American Museum Novitates, v. 3394, p. 1-42.

Martin, R.A., 2005, Conservation of freshwater and euryhaline elasmobranchs: a review: Journal of the Marine Biological Association of the United Kingdom, v. 85, p. 1049-1073.

McArthur, J.M., 1994, Recent trends in strontium isotope stratigraphy: Terra Nova, v. 6, p. 331-358

McArthur, J.M., Howarth, R.J., and Bailey, T.R., 2001, Strontium isotope stratigraphy: LOWESS version 3: best fit to the marine Sr-isotope curve for 0-509 Ma and accompanying look-up table for deriving numerical age: The Journal of Geology, v. 109, p. 155-170.

McEachran, J.D., 1995, Urolophidae. Rayas redondas, in Fischer, W., Krupp, F., Schneider, W., Sommer, C., Carpenter, K.E., and Niem, V., eds., Guia FAO para Identification de Especies para lo Fines de la Pesca: Pacifico Centro-Oriental, v. 3, p. $786-792$

McEachran, J.D., and Carvalho, M.D., 2002, Batoid fishes, in Carpenter, K.E., ed., The Living Marine Resources of the Western Central Atlantic Volume 1: Introduction, Molluscs, Crustaceans, Hagfishes, Sharks, Batoid Fishes and Chimaeras. FAO Species Identification Guide for Fisheries Purposes and American Society of Ichthyologists and Herpetologist Special Publication No 5: Rome, Food and Agriculture Organization of the United Nations, v. 1, p. 507-589.
McEachran, J.D., and Notarbartolo di Sciara, G., 1995, Mobulidae. Mantas, diablos, in Fischer, W., Krupp, F., Schneider, W., Sommer, C., Carpenter, K.E., and Niem, V., eds., Guia FAO para Identification de Especies para los Fines de la Pesca. Pacifico Centro Oriental, 3 v.: Rome, Food and Agriculture Organization of the United Nations, p. 759-764.

McEachran, J.D., Dunn, K.A., and Miyake, T., 1996, Interrelationships of the batoid fishes (Chondrichthyes: Batoidei), in Stiassny, M.L.J., Parenti, L.R., and Johnson, G.D., eds., Interrelationships of Fishes: San Diego, London, Academic Press, p. 63-84.

McMillan, P.J., Griggs, L.H., Francis, M.P., Marriott, P.J., Paul, L.J., Mackay, E. Wood, B.A., Sui, H., and Wei, F., 2011, New Zealand fishes. Volume 3: a field guide to common species caught by surface fishing: New Zealand Aquatic Environment and Biodiversity Report No. 69, 145 p.

Michael, S.W., 1993, Reef Sharks and Rays of the World. A Guide to Their Identification, Behavior, and Ecology: Monterey, CA, Sea Challengers, $107 \mathrm{p}$

Mondal, S., Das, S., Mallick, S., and Adhikary, D., 2009, Miocene shark teeth assemblages and ancillary fish taxa from Baripada, Orissa: taxonomic revision and a global palaeobiogeographic overview: Journal of the Palaeontological Society of India, v. 54, p. 1-135.

Montes, C., Bayona, G.A., Cardona, A.A., Bush, D.M., Silva, C.A., Moron, S.E., Hoyos, N., Ramirez, D.A., Jaramillo, C.A., and Valencia, V., 2012a, Arc-continent collision and orocline formation: closing of the Central American seaway: Journal of Geophysical Research, v. 117, B04105.

Montes, C., Cardona, A., Bayona, G.A., McFadden, R., Buchs, D.M., Morón, S.E., Silva, C.A., Hoyos, N., Restrepo-Moreno, S., Ramírez, D.A., Wilson, J., Ortiz, J., Farris, D., Jaramillo, C.A., Valencia, V., Bryan, J., and Flores, J.A., 2012b, Evidence for middle Eocene and younger land emergence in central Panama: Implications for Isthmus closure: Bulletin of the Geological Society of America, v. 124, p. 780-799.

Moore, J.C., 2001, Diversity, taxonomic versus functional, in Levin, S., ed., Encyclopedia of Biodiversity: Oxford, Elsevier, v. 2, p. 205-215.

Moss, M.L., 1977, Skeletal tissues in sharks: American Zoologist, v. 17, p. 335-392.

Müller, J., and Henle, F.G.J., 1837, Gattungen der Haifische und Rochen nach einer vom ihm mit Hrn Henle unternomenen gemeinschaftlichen Arbeit uber die Naturgeschichte der Knorpelfische: Berichte der königlich preussischen Akademie der Wissenschaften Berlin, v. 1837, p. $111-118$.

Müller, J., and Henle, F.G.J., 1838, On the generic characters of cartilaginous fishes: Magazine of Natural History, v. 2, p. 33-91.

Müller, J., and Henle, F.G.J., 1839-1841, Systematische Beschreibung der Plagiostomen: Berlin, Verlag von Veit and Co., $200 \mathrm{p}$.

Mundy, B.C., 2005, Checklist of the fishes of the Hawaiian Archipelago: Bishop Museum Bulletins in Zoology, v. 6, p. 1-704.

Nair, R.V., and Soundararajan, R., 1976, On the occurrence of the stingray Dasyatis (Dasyatis) microps (Annandale) on the Madras Coast and in the Gulf of Mannar: Indian Journal of Fisheries, v. 23, p. 278-279.

Nardo, J.D., 1827, Prodromus observationum et disquisitionum ichthyologiae Adriaticae: Oken's Isis, v. 20, p. 472-631.

Naylor, G.J.P., and Marcus, L.F., 1994, Identifying isolated shark teeth of the genus Carcharhinus to species: relevance for tracking phyletic change through the fossil record: American Museum Novitates, v. 3109, p. 1-53.

Nieves-Rivera, A.M., Ruiz-Yantin, M., and Gottfried, M.D., 2003, New record of the Lamnid Shark Carcharodon megalodon from the middle Miocene of Puerto Rico: Caribbean Journal of Science, v. 39, p. 223-227.

Norman, J.R., 1939, Fishes. The John Murray Expedition 1933-34: Scientific Reports, John Murray Expedition, v. 7, p. 1-116.

Notarbartolo Di Sciara, G., 1987, A revisionary study of the genus Mobula Rafinesque, 1810 (Chondrichthyes: Mobulidae) with the description of a new species: Zoological Journal of the Linnean Society, v. 91, p. 1-91.

Notarbartolo Di Sciara, G., 1988, Natural history of the rays of the genus Mobula in the Gulf of California: Fishery Bulletin, v. 86, p. 45-66.

Nyberg, K.G., Ciampaglio, C.N., and Wray, G.A., 2006, Tracing the ancestry of the great white shark, Carcharodon carcharias, using morphometric analyses of fossil teeth: Journal of Vertebrate Paleontology, v. 26, p. 806-814.

Oksanen, J., Blanchet, F.G., Kindt, R., Legendre, P., O'Hara, R.G., Simpson, G.L. Solymos, P., Stevens, M.H.H., and Wagner, H., 2010, Vegan: community ecology package: $\mathrm{R}$ package, version $1.17-0$.

Peron, F., and Lesueur, C.A., 1822, Description of a Squalus, of a very large size, which was taken on the coast of New Jersey: Journal of the Philadelphia Academy of Natural Sciences, v. 2, p. 343-352.

Petchey, O.L., and Gaston, K.J., 2006, Functional diversity: back to basics and looking forward: Ecology Letters, v. 9, p. 741-758.

Peyer, B., 1968, Comparative Odontology: Chicago, University of Chicago Press, $347 \mathrm{p}$.

Philippi, R.A., 1892, Algunos peces de Chile: Anales del Museo Nacional de Chile: Primera seccion, Zoología, v. 3, p. 1-17. 
Philippi, R.A., 1893, Algunos peces de Chile: Anales del Museo Nacional de Chile, v. 1, n. 3, p. 1-17.

Pimiento, C., and Balk, M.A., 2015, Body-size trends of the extinct giant shark Carcharocles megalodon: a deep-time perspective on marine apex predators: Paleobiology, v. 41, p. 479-490.

Pimiento, C., and Clements, C.F., 2015, When did Carcharocles megalodon become extinct? A new analysis of the fossil record: PLoS ONE, 10(1), e111086.

Pimiento, C., Ehret, D.J., MacFadden, B.J., and Hubbell, G., 2010, Ancient nursery area for the extinct giant shark Megalodon from the Miocene of Panama: PLoS ONE, 5(5), e10552.

Pimiento, C., González-Barba, G., Ehret, D.J., Hendy, A.J., MacFadden, B.J., and Jaramillo, C., 2013a, Sharks and rays (Chondrichthyes, Elasmobranchii) from the late Miocene Gatun Formation of Panama: Journal of Paleontology, v. 87, p. 755-774.

Pimiento, C., Gonzalez-Barba, G., Hendy, A.J., Jaramillo, C., MacFadden, B.J., Montes, C., Suarez, S. C., and Shippritt, M., 2013b, Early Miocene chondrichthyans from the Culebra Formation, Panama: a window into marine vertebrate faunas before closure the Central American Seaway: Journal of South American Earth Sciences, v. 42, p. 159-170.

Pimiento, C., MacFadden, B.J., Clements, C.F., Varela, S., Jaramillo, C., Velez-Juarbe, J., and Silliman, B.R., 2016, Geographical distribution patterns of Carcharocles megalodon over time reveal clues about extinction mechanisms: Journal of Biogeography doi: 10.1111/jbi.12754.

Poey, F., 1868, Synopsis piscium cubensium: Catalogo Razonado de los peces de la isla de Cuba: Repertorio Fisico-Natural de la Isla de Cuba, v. 2, p. $279-484$.

Portell, R.W., Hubbell, G., Donovan, S.K., Green, J.L., Harper, D.A.T., and Pickerill, R., 2008, Miocene sharks in the Kendeace and Grand Bay formations of Carriacou, The Grenadines, Lesser Antilles: Caribbean Journal of Science, v. 44, p. 279-286.

Purdy, R.W., 1996, Paleoecology of fossil white sharks, in Klimley, A., and Ainley, D., eds., Great White Sharks: The Biology of Carcharodon carcharias: San Diego, CA, Academic Press, p. 67-78.

Purdy, R.W., Schneider, V.P., Applegate, S.P., McLellan, J.H., Meyer, R.L., and Slaughter, B.H., 2001, The Neogene sharks, rays, and bony fishes from Lee Creek Mine, Aurora, North Carolina: Smithsonian Contributions to Paleobiology, v. 90, p. 71-202.

Quoy, J.R.C., and Gaimard, P., 1824-1825, Description des Poissons. Chapitre IX, in Freycinet, L.de, ed., Voyage autour du Monde...exécuté sur les corvettes de L. M. "L'Uranie" et "La Physicienne," pendant les années 1817, 1818, 1819 et 1820 . Description des Poissons. Zoologie: Paris, Ch. 9., p. 192-401. (1-328 in 1824; 329-616 in 1825)

R Development Core Team, 2012, R: A language and environment for statistical computing: Vienna, Austria, R Foundation for Statistical Computing, ISBN 3-900051-07-0, www.r-project.org/.

Radcliffe, L., 1916, The Sharks and Rays of Beaufort, North Carolina: Bulletin of the U.S. Bureau of Fisheries, v. 34, p. 239-384.

Rafinesque, C.S., 1810, Caratteri di alcuni nuovi generi e nouve specie di Animali e Piante della Sicilia con varie osservazioni sopra I medesimi: Palermo, Per le stampe di Sanfilippo, $105 \mathrm{p}$.

Reif, W.-E., 1988, Evolution of high swimming velocities in sharks-a case of escalation?: Neues Jahrbuch für Geologie und Palaontologie, Monatshefte, v. 6 , p. $361-379$.

Reiner, F., 1996, Catálogo dos peixes do arquipélago de Cabo Verde: Publicações avulsas do IPIMAR, v. 2, 339 p.

Reis, M.A.F., 2005, Chondrichthyan fauna from the Pirabas Formation, Miocene of northern Brazil, with comments on paleobiogeography: Anuarrio do Instituto de Geociencias, v. 28, p. 31-58.

Ritter, E.K., 2014, Coasting of pelagic thresher sharks, Alopias pelagicus, in comparison to two other species of the same ecomorphotype, and the limitation of video capturing in natural settings: Environmental Sciences, v. 2, p. $13-23$

Roberts, T.R., and Karnasuta, J., 1987, Dasyatis laosensis, a new whiptailed stingray (family Dasyatidae), from the Mekong River of Laos and Thailand: Environmental Biology of Fishes, v. 20, p. 161-167.

Ruppell, W.P.E.S., 1835-1838, Neue Wirbelthiere zu der Fauna von Abyssinien gehorig entdeckt und beschrieben von Dr. Eduard Ruppell. Fisches des rothen Meeres: Frankfurt am Main, Siegmund Schmerber, 148 p.

Sanchez-Villagra, M.R., Burnham, R.J., Campbell, D.C., Feldmann, R.M., Gaffney, E.S., Kay, R.F., Lozsan, R., Purdy, R., and Thewissen, J.G.M., 2000, A new near-shore marine fauna and flora from the early Neogene of northwestern Venezuela: Journal of Paleontology, v. 74, p. 957-968.

Schwartz, F.J., 2007, Tail spine characteristics of stingrays (Order Myliobatiformes) frequenting the FAO fishing area $61\left(20^{\circ} \mathrm{N} 120^{\circ} \mathrm{E}-50^{\circ} \mathrm{N} 150^{\circ} \mathrm{E}\right)$ of the northwest Pacific Ocean: Raffles Bulletin of Zoology, Supplement 14, p. $121-130$.
Sepulchre, P., Arsouze, T., Donnadieu, Y., Dutay, J.C., Jaramillo, C., Le Bras, J., Martin, E., Montes, C., and Waite, A.J., 2014, Consequences of shoaling of the Central American Seaway determined from modeling Nd isotopes: Paleoceanography, v. 29, p. 176-189.

Shelton, B.J., 1952, Geology and Petroleum Prospects of Darien, Southeastern Panama [M.S. Thesis]: Corvallis, OR, Oregon State University, 67 p.

Silas, E.G., and Selvaraj, G.S.D., 1985, On the occurrence of the rough-tail stingray Dasyatis centroura (Mitchill) in Indian waters: Indian Journal of Fisheries, v. 32, p. 248-255.

Smith, C.L., 1997, National Audubon Society Field Guide to Tropical Marine Fishes of the Caribbean, the Gulf of Mexico, Florida, the Bahamas, and Bermuda: New York, Alfred A. Knopf, Inc., 720 p.

Smith, S.E., Rasmussen, R.C., Ramon, D.A., and Cailliet, G.M., 2008, The biology and ecology of thresher sharks (Alopiidae), in Camhi, M.D., Pikitch, E.K., and Babcock, E.A., eds., Sharks of the Open Ocean: Biology, Fisheries and Conservation: Oxford, UK, Blackwell Publishing Ltd, p. 60-68. DOI: 10.1002/9781444302516.ch4.

Sommer, C.W., Schneider, W., and Poutiers, J.-M., 1996, FAO Species Identification Field Guide for Fishery Purposes. The living marine resources of Somalia: Rome, Food and Agriculture Organization of the United Nations, $376 \mathrm{p}$.

Springer, V.G., 1964, A revision of the carcharhinid shark genera Scoliodon, Loxodon, and Rhizoprionodon: Proceedings of the U.S. National Museum, v. 115 , p. $559-632$.

Springer, V.G., and Gold, J.P., 1989, Sharks in Question: Washington, DC, Smithsonian Institution Press, $176 \mathrm{p}$.

Stewart, R.H., 1966, The Rio Bayano Basin, A geologic report: Unpublished report of the Inter Oceanic Canal Studies, Panama Canal Company, Memorandum PCC-4, $18 \mathrm{p}$.

Storm, R., 1894, Troisieme note sur les poisons du terrain rupelien: Bulletin de la Société Belge de Géologie, de Paléontologie et d'Hydrologie, v. 8, p. $67-82$.

Terry, R.A., 1956, A geological reconnaissance of Panama: Occasional Papers of the California Academy of Sciences, v. 23, p. 1-91.

Tessman, N., 1966, Cenozoic Sharks of Florida [M.S. thesis]: Gainesville, FL, University of Florida, Florida State Museum, 132 p.

Uhen, M. D., Coates, A. G., Jaramillo, C. A., Montes, C., Pimiento, C., Rincon, A., Strong, N., and Velez-Juarbe, J., 2010, Marine mammals from the Miocene of Panama: Journal of South American Earth Sciences, v. 30, p. $167-175$.

Valerio, A.L., and Laurito, C.A., 2008, Dental remains of immature individuals of Rhynchotherium blicki (Frick 1933) of San Gerardo de Limoncito, Coto Brus, Costa Rica: Revista Geológica de América Central, v. 39, p. 87-91.

Vasquez, S., and Pimiento, C., 2014, Sharks and Rays from the Tonosi Formation (Eocene of Panamá): Revista Geológica de América Central, v. 51, p. $165-169$

Velez-Juarbe, J., Wood, A.R., De Gracia, C., and Hendy, A.J., 2015, Evolutionary patterns among living and fossil kogiid sperm whales: evidence from the Neogene of Central America: PLoS ONE, 10(5), e0129186.

Ward, D., and Bonavia, C., 2001, Additions to, and a review of, the Miocene shark and ray fauna of Malta: The Central Mediterranean Naturalist, v. 3, p. 131-146.

White, W.T., Ebert, D.A., Naylor, G.J.P., Ho, H.-H., Clerkin, P., Veríssimo, A., and Cotton, C.F., 2013, Revision of the genus Centrophorus (Squaliformes: Centrophoridae): Part 1 Redescription of Centrophorus granulosus (Bloch \& Schneider), a senior synonym of C. acus and C. niaukang Teng: Zootaxa, v. 3752(1), p. 035-072.

Whitley, G.P., 1929, Studies in ichthyology: Records of the Australian Museum, v. 17 , p. 101-143.

Whitley, G.P., 1939, Taxonomic notes on sharks and rays: Australian Zoologist, v. 9 , p. $227-262$.

Whitley, G.P., 1940, The fishes of Australia, Pt. I: The sharks, rays, devilfish, and other primitive fishes of Australia and New Zealand: Sydney, Australia, Royal Zoological Society of New South Wales, $280 \mathrm{p}$.

Winkler, T.C., 1876, Deuxième mémoires sur des dents de poissons fossiles du terrain bruxellien: Archives du Musée Teyler, v. 4, p. 16-48.

Yamada, U., Shirai, S., Irie, T., Tokimura, M., Deng, S., Zheng, Y., Li, C., Kim, Y.U., and Kim, Y.S., 1995, Names and illustrations of fishes from the East China Sea and the Yellow Sea: Tokyo, Japan, Overseas Fishery Cooperation Foundation, $288 \mathrm{p}$.

Zhou, S., and Griffiths, S.P., 2008, Sustainability Assessment for Fishing Effects (SAFE): A new quantitative ecological risk assessment method and its application to elasmobranch bycatch in an Australian trawl fishery: Fisheries Research, v. 91, p. 56-68.

Accepted 17 February 2017 